\title{
The Third Spectrum of Praseodymium (Pr III) in the Vacuum Ultraviolet
}

\author{
Jack Sugar \\ Institute for Basic Standards, National Bureau of Standards, Washington, D.C. 20234
}

(February 13, 1969)

\begin{abstract}
Measurements of the spectrum of doubly ionized praseodymium from 821 to $2103 \AA$ are given. One hundred fifty-three energy levels deduced from these wavelengths and an earlier line-list of longer wavelengths are presented. These levels are identified with the configurations $4 f^{2} 6 s, 4 f^{2} 7 s, 4 f^{2} 8 s$, $4 f^{2} 6 p, 4 f^{2} 6 d, 4 f^{2} 5 f, 5 d^{2} 4 f$, and $4 f 5 d 6 s$ and are given term designations. Radial energy integrals belonging to these configurations are parametrically deduced from the known levels.

A value of $21.625 \mathrm{eV}\left(174420 \mathrm{~cm}^{-1}\right)$ for the ionization energy of Pr III, with an estimated uncertainty of $0.016 \mathrm{eV}\left(130 \mathrm{~cm}^{-1}\right)$, is derived from the $4 f^{2} n s$ series $(n=6,7,8)$.
\end{abstract}

Key words: Energy levels; interaction parameters; praseodymium; third spectrum; vacuum ultraviolet; wavelengths.

\section{Introduction}

The analysis of PrIII in the wavelength range from 2025 to $10716 \AA[1,2]^{1}$ revealed nearly completely the energy level structure of the four low-lying configurations $4 f^{3}, 4 f^{2} 5 d, 4 f^{2} 6 s$, and $4 f^{2} 6 p$, and some levels of $5 d^{2} 4 f$ and $4 f^{2} 6 d$. I have extended the observations to shorter wavelengths and measured 2948 lines in the range from 821 to $2103 \AA$. These new data have led to a considerable increase in the number of known levels of the $5 d^{2} 4 f$ configuration and to the discovery of levels belonging to the $4 f 5 d 6 s, 4 f^{2} 5 f$, and $4 f^{2} 8 s$ configurations. In addition, a reexamination of the old line-list yielded more levels of the configurations $4 f^{2} 6 s, 4 f^{2} 6 d$, and $4 f^{2} 7 s$. In all, 153 energy levels of Pr III have been newly established.

The configurations to which they belong were treated theoretically for the purpose of determining parametrically the radial energy integrals and of calculating the level positions and eigenvectors. These calculations helped to confirm the experimental results and to locate unknown levels, as well as to provide an interpretation of the configurations in the most appropriate coupling schemes.

Of particular interest are the mutually interacting odd configurations $4 f^{2} 6 p, 5 d^{2} 4 f$, and $4 f 5 d 6 s$, which were treated as one complex. Many levels are strongly perturbed and were found to contain large percentages of terms of several configurations. In the $5 d^{2} 4 f$ configuration the addition of an "effective" two-body configuration interaction parameter for nonequivalent

${ }^{1}$ Figures in brackets indicate the literature references at the end of this paper. electrons decreased the rms error of the calculation by 25 percent.

The ionization energy of Pr III was calculated in ref. 2 by means of tentatively identified $4 f^{2} 6 d$ levels to form a $4 f^{2}\left({ }^{3} \mathrm{H}\right) n d(n=5,6)$ series. The new analysis provides the $4 f^{2}\left({ }^{3} \mathrm{H}\right) n s$ series $(n=6,7,8)$ with which to determine a more reliable value.

Three levels given in reference 2 which were found to be poorly substantiated and have now been discarded are listed below:

\begin{tabular}{c|c|c|c}
\hline \hline Rejected levels & $J$ & Config. & New levels \\
\hline $45848.37 \mathrm{~cm}^{-1}$ & $2 \frac{1}{2}$ & $4 f^{2} 6 s$ & $45807.16 \mathrm{~cm}^{-1}$ \\
$68676.55 \mathrm{~cm}^{-1}$ & $2 \frac{1}{2}$ & $4 f^{2} 6 p$ & \\
$79378.43 \mathrm{~cm}^{-1}$ & $2 \frac{1}{2}$ & $4 f^{2} 6 p$ & $79366.69 \mathrm{~cm}^{-1}$ \\
\hline
\end{tabular}

\section{Observations}

For the most part, the procedure outlined in reference 2 for obtaining the spectrum PrIII has been followed. The sliding spark was operated at peak currents of 50 and $500 \mathrm{~A}$ to enhance the third and fourth spectra selectively. I departed from the earlier method of producing the second spectrum by means of an arc. Instead a 6 A sliding spark was used which gave a more clear-cut distinction between second and third spectra when compared with the $50 \mathrm{~A}$ spark, as well as sharper lines. This technique has already been used in the classification of Ce III [3].

The new extension of the observations of Pr III to shorter wavelengths was made with a $10.3 \mathrm{~m}$ Eagle vacuum spectrograph, utilizing a grating of 1200 


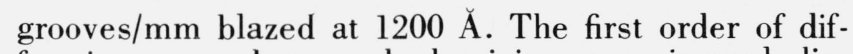
fraction was photographed, giving a reciprocal dispersion of $0.78 \AA / \mathrm{mm}$. One half to $2 \mathrm{hr}$ exposures were required to record the spectrum of the spark, operating at a repetition rate of 15 sparks per second. Calibration spectra of $\mathrm{C}, \mathrm{N}$. O, Ar, Si, Ge, and Cư $[4,5,6$, $7,8]$ were obtained from pulsed rf-excited electrodeless lamps and hollow cathode discharges.

Two to five measurements of the lines in the $50 \mathrm{~A}$ spark were made, the number depending on the recurrence of a line on progressively weaker exposures. From the variation of wavelengths obtained with different exposures the accuracy of the final values is estimated to be $\pm 0.004 \AA$. Systematic shifts between the various sets of measurements were removed by standardizing on wavelengths of internal impurities of $\mathrm{C}, \mathrm{N}, \mathrm{O}$, and $\mathrm{Si}$.

The new measurements overlap the previous list [1] in the region from 2000 to $2103 \AA$ and considerably augment it, thus indicating that stronger exposures may be needed beyond this overlap. Lines of intensity designated as 1 in the old list are usually assigned 200 in the new list, and the other common lines are correspondingly stronger.
A complete tabulation of the newly observed lines appears in table $X$. The wavelengths given in the first column are the values in vacuum. Following this are the visually estimated intensities with the following descriptive notations:

$c l=$ measurement affected by a close neighboring line, $b l=$ a blend of two or more lines,

$h=$ hazy,

$w=$ wide.

Under "classification" appear the two energy levels from which the line originates, followed by a subscript $J$-value, and where appropriate a superscript degree mark representing odd parity. Double classifications of lines are given without repeating the wavelength.

In table I, newly classified lines from the longer wavelength list of reference 1 are given. Among these are lines having hfs, for which the following additional notations in the intensity column appear:

${ }^{*} r=$ strongest component of flag pattern shaded to red, $* v=$ strongest component of flag pattern shaded to violet,

Table I. Newly classified lines of Pr III, $\lambda>2103 \AA$

\begin{tabular}{|c|c|c|c|c|c|c|c|}
\hline$\lambda_{\text {air }}$ & Intensity & $\begin{array}{c}\sigma \\
\left(\mathrm{cm}^{-1}\right)\end{array}$ & Classification & $\lambda_{\text {air }}$ & Intensity & $\begin{array}{c}\sigma \\
\left(\mathrm{cm}^{-1}\right)\end{array}$ & Classification \\
\hline 4650.609 & $9^{*} v$ & 21496.54 & $13887^{\circ}{ }_{7 / 2}-35384_{5 / 2}$ & 3011.282 & $20^{*} v$ & 33198.77 & $50227_{5 / 2}-83426_{5 / 2}^{\circ}$ \\
\hline 4334.697 & $9 w$ & 23063.18 & $11761_{9 / 2}^{\circ}-34825_{7 / 2}$ & 3006.469 & $60 * r$ & 33251.92 & $38726_{7 / 2}-71978^{\circ}{ }_{7 / 2}$ \\
\hline 3607.068 & $4^{*} r$ & 27715.46 & $52026_{3 / 2}-79742^{\circ}{ }_{1 / 2}$ & 3004.002 & $10 * r$ & 33279.22 & $52026_{3 / 2}-85306_{5 / 2}^{\circ}$ \\
\hline 3577.336 & $8^{*} v$ & 27945.80 & $33659_{5 / 2}-61605_{7 / 2}^{\circ}$ & 3002.106 & 2 & 33300.24 & $38694_{5 / 2}-71994_{5 / 2}^{\circ}$ \\
\hline 3567.897 & $1 b l$ & 28019.71 & $50869_{1 / 2}-78889_{3 / 2}^{\circ}$ & 2982.236 & $9 * r$ & 33522.11 & $45844_{3 / 2}-79366_{5 / 2}^{\circ}$ \\
\hline 3565.845 & $9 * v$ & 28035.78 & $50658_{13 / 2}-78694_{11 / 2}^{\circ}$ & 2980.583 & $5 * r$ & 33540.70 & $50869_{1 / 2}-84409^{\circ}{ }_{3 / 2}$ \\
\hline 3564.405 & $30 * r$ & 28047.13 & $50647_{11 / 2}-78694_{11 / 2}^{\circ}$ & 2978.907 & $9^{*} v$ & 33559.57 & $45807_{5 / 2}-79366_{5 / 2}^{\circ}$ \\
\hline 3510.532 & $20 * v$ & 28477.56 & $50658_{13 / 2}-79136_{13 / 2}^{\circ}$ & 2976.347 & $40 * v$ & 33588.43 & $45807_{5 / 2}-79395_{7 / 2}^{\circ}$ \\
\hline 3509.142 & $3 * r$ & 28488.86 & $50647_{11 / 2}-79136_{13 / 2}^{\circ}$ & 2963.032 & 2 & 33739.36 & $36642_{13 / 2}-70381_{13 / 2}^{\circ}$ \\
\hline 3462.700 & $1^{*} r$ & 28870.93 & $52026_{3 / 2}-80897^{\circ}{ }_{3 / 2}$ & & & & \\
\hline 3462.432 & $1 * r$ & 28873.16 & $50869_{1 / 2}-79742_{1 / 2}^{\circ}$ & 2940.896 & $7^{*} v$ & 33993.30 & $51312_{5 / 2}-85306_{5 / 2}^{\circ}$ \\
\hline 3412.607 & $7 * r$ & 29294.71 & $50869_{1 / 2}-80164_{3 / 2}^{\circ}$ & 2933.827 & 1 & 34075.21 & $37919_{7 / 2}-71994_{5 / 2}^{\circ}$ \\
\hline 3402.969 & $50 * r$ & 29377.68 & $52026_{3 / 2}-81404_{5 / 2}^{\circ}$ & 2930.192 & $50 * v$ & 34117.48 & $35291_{9 / 2}-69408_{11 / 2}^{\circ}$ \\
\hline 3379.131 & $50 * v$ & 29584.91 & $51312_{5 / 2}-80897_{3 / 2}^{\circ}$ & 2924.661 & $2^{*} v$ & 34181.99 & $50227_{3 / 2}-84409^{\circ}{ }_{3 / 2}$ \\
\hline 3377.141 & $100 * v$ & 29602.34 & $45807_{5 / 2}-75409_{3 / 2}^{\circ}$ & 2910.612 & $70^{*} v$ & 34346.98 & $28885_{9 / 2}-63232^{\circ}{ }_{7 / 2}$ \\
\hline 3367.350 & $200 * v$ & 29688.42 & $35291_{9 / 2}-64979^{\circ}{ }_{7 / 2}$ & 2890.842 & 2 & 34581.86 & $39024_{9 / 2}-73606_{9 / 2}^{\circ}$ \\
\hline 3359.973 & $3 * v$ & 29753.59 & $45807_{5 / 2}-75560_{5 / 2}^{\circ}$ & 2885.001 & $6^{*} r$ & 34651.87 & $38726_{7 / 2}-73378_{7 / 2}^{\circ}$ \\
\hline 3358.083 & $30 * r$ & 29770.34 & $45844_{3 / 2}-75614_{5 / 2}^{\circ}$ & 2876.229 & 1 & 34757.55 & $69138_{9 / 2}^{\circ}-103895_{7 / 2}$ \\
\hline 3353.866 & $50 * v$ & 29807.77 & $45807_{5 / 2}-75614_{5 / 2}^{\circ}$ & 2857.700 & 4 & 34982.90 & $37011_{5 / 2}-71994_{5 / 2}^{\circ}$ \\
\hline 3322.203 & $6^{*} v$ & 30091.85 & $51312_{5 / 2}-81404_{5 / 2}^{\circ}$ & 2851.486 & $6^{*} r$ & 35059.13 & $33466_{11 / 2}-68525^{\circ} 11 / 2$ \\
\hline 3161.330 & $7 * r$ & 31623.10 & $50869_{1 / 2}-82492_{3 / 2}^{\circ}$ & 2838.461 & $7 * r$ & 35220.00 & $35801_{7 / 2}-71021_{9 / 2}^{\circ}$ \\
\hline 3147.878 & $9 * v$ & 31758.23 & $35291_{9 / 2}-67049_{9 / 2}^{\circ}$ & 2827.668 & 3 & 35354.43 & $36640_{7 / 2}-71994^{\circ}{ }_{5 / 2}^{\circ}$ \\
\hline 3122.646 & $7 * v$ & 32014.84 & $45807_{5 / 2}-77821_{5 / 2}^{\circ}$ & 2819.342 & 2 & 35458.83 & $37919_{7 / 2}-73378^{\circ}{ }_{7 / 2}$ \\
\hline 3108.884 & $7 * r$ & 32156.56 & $50869_{1 / 2}-83025_{3 / 2}^{\circ}$ & 2812.509 & $9 * v$ & 35544.98 & $32760_{13 / 2}-68305^{\circ}{ }_{15 / 2}$ \\
\hline 3098.474 & $3 * v$ & 32264.59 & $50227_{3 / 2}-82492_{3 / 2}^{\circ}$ & 2803.090 & 3 & 35664.41 & $48745_{5 / 2}-84409^{\circ}{ }_{3 / 2}$ \\
\hline 3087.175 & $1 * r$ & 32382.56 & $52026_{3 / 2}-84409^{\circ}{ }_{3 / 2}$ & 2797.924 & $1 b l$ & 35730.25 & $65935_{7 / 2}^{\circ}-101665_{5 / 2}$ \\
\hline 3061.277 & $9^{*} v$ & 32656.61 & $45807_{5 / 2}-78463_{7 / 2}^{\circ}$ & 2784.154 & 1 & 35906.96 & $39732_{11 / 2}-75640^{\circ}{ }_{11 / 2}$ \\
\hline 3039.680 & 7 & 32888.63 & $45805_{9 / 2}-78694_{11 / 2}^{\circ}$ & 2776.318 & 4 & 36008.30 & $48401_{3 / 2}-84409^{\circ}{ }_{3 / 2}$ \\
\hline 3036.913 & 8 & 32918.59 & $44903_{5 / 2}-77822_{5 / 2}^{\circ}$ & 2774.708 & 4 & 36029.19 & $39732_{11 / 2}-75762_{9 / 2}^{\circ}$ \\
\hline 3018.701 & $20 * v$ & 33117.19 & $51312_{5 / 2}-84430_{7 / 2}^{\circ}$ & 2766.880 & 3 & 36131.12 & $35863_{3 / 2}-71994^{\circ}{ }_{5 / 2}^{\circ}$ \\
\hline
\end{tabular}


TABLE I. Newly classified lines of Pr III, $\lambda>2103 \AA$-Continued

\begin{tabular}{|c|c|c|c|c|c|c|c|}
\hline $\begin{array}{c}\lambda_{\text {air }} \\
\AA\end{array}$ & Intensity & $\begin{array}{c}\sigma \\
\left(\mathrm{cm}^{-1}\right)\end{array}$ & Classification & $\begin{array}{c}\lambda_{\text {air }} \\
\AA\end{array}$ & Intensity & $\begin{array}{c}\sigma \\
\left(\mathrm{cm}^{-1}\right)\end{array}$ & Classification \\
\hline 2741.262 & 1 & 36468.76 & $66148_{13 / 2}^{\circ}-102617_{11 / 2}$ & 2564.509 & 4 & 38982.14 & $65922^{\circ}{ }_{11 / 2}-104904_{11 / 2}$ \\
\hline 2734.368 & 8 & 36560.70 & $48745_{5 / 2}-85306_{5 / 2}^{\circ}$ & 2563.474 & 6 & 38997.87 & $36642_{13 / 2}-75640^{\circ}{ }_{11 / 2}$ \\
\hline 2732.952 & 1 & 36579.64 & $68987^{\circ}{ }_{7 / 2}-105566_{9 / 2}$ & 2561.773 & 6 & 39023.77 & $63593_{9 / 2}^{\circ}-102617_{11 / 2}^{\circ}$ \\
\hline 2720.409 & 1 & 36748.29 & $66735^{\circ}{ }_{13 / 2}-103484_{15 / 2}$ & 2559.865 & 1 & 39052.85 & $68801_{7 / 2}^{\circ}-107854_{9 / 2}$ \\
\hline 2712.384 & 2 & 36857.01 & $35137_{3 / 2}-71994_{5 / 2}^{\circ}$ & 2559.277 & 2 & 39061.82 & $63768_{7 / 2}^{\circ}-102830_{9 / 2}^{\circ}$ \\
\hline 2707.422 & 2 & 36924.56 & $68525^{\circ} 11 / 2-105450_{11 / 2}$ & 2558.675 & 5 & 39071.01 & $61717_{5 / 2}^{\circ}-100788_{7 / 2}$ \\
\hline 2706.611 & 5 & 36935.62 & $36670_{11 / 2}-73606_{9 / 2}^{\circ}$ & 2558.537 & 4 & 39073.12 & $61357_{9 / 2}^{\circ}-100430_{9 / 2}$ \\
\hline 2704.403 & 1 & 36965.78 & $36640_{7 / 2}-73606_{9 / 2}^{\circ}$ & 2557.323 & 3 & 39091.67 & $36670_{11 / 2}-75762_{9 / 2}^{\circ}$ \\
\hline 2699.300 & $5 * r$ & 37035.65 & $38726_{7 / 2}-75762_{9 / 2}^{\circ}$ & 2556.813 & 4 & 39099.46 & $64235_{9 / 2}^{\circ}-103335_{9 / 2}$ \\
\hline 2687.981 & $6^{*} v$ & 37191.60 & $38448_{9 / 2}-75640_{11 / 2}^{\circ}$ & 2555.353 & 7 & 39121.80 & $62558_{11 / 2}^{\circ}-101680_{13 / 2}^{\circ}$ \\
\hline 2687.506 & 1 & 37198.17 & $63232^{\circ}{ }_{7 / 2}-100430_{9 / 2}$ & 2554.979 & 1 & 39127.53 & $38694_{5 / 2}-77822_{5 / 2}^{\circ}$ \\
\hline 2686.455 & 3 & 37212.73 & $63576_{5 / 2}^{\circ}-100788_{7 / 2}$ & 2549.531 & 1 & 39211.13 & $67870_{9 / 2}^{\circ}-107081_{9 / 2}$ \\
\hline 2673.055 & 5 & 37399.26 & $65909^{\circ}{ }_{5 / 2}-103308_{7 / 2}$ & 2545.790 & 9 & 39268.75 & $64215^{\circ}{ }_{13 / 2}-103484_{15 / 2}$ \\
\hline 2666.218 & 2 & 37495.16 & $63576_{5 / 2}^{\circ}-101071_{5 / 2}$ & 2543.644 & 1 & 39301.88 & $66148_{13 / 2}^{\circ}-105450_{11 / 2}^{\circ}$ \\
\hline 2663.415 & 3 & 37534.62 & $65295^{\circ}{ }_{7 / 2}-102830_{9 / 2}$ & 2541.080 & 8 & 39341.53 & $61605_{7 / 2}^{\circ}-100947_{9 / 2}$ \\
\hline 2650.675 & 1 & 37715.01 & $63232_{7 / 2}^{\circ}-100947_{9 / 2}$ & 2540.311 & 7 & 39353.44 & $61717_{5 / 2}^{\circ}-101071_{5 / 2}$ \\
\hline 2647.019 & 1 & 37767.10 & $68978_{5 / 2}^{\circ}-106745_{5 / 2}^{\circ}$ & 2539.759 & 5 & 39361.99 & $68492_{7 / 2}^{\circ}-107854_{9 / 2}$ \\
\hline 2640.290 & 4 & 37863.35 & $68801^{\circ}{ }_{7 / 2}-106665_{7 / 2}$ & 2537.099 & 2 & 39403.26 & $39732_{11 / 2}-79136_{13 / 2}^{\circ}$ \\
\hline 2634.707 & 5 & 37943.58 & $69138_{9 / 2}^{\circ}-107081_{9 / 2}$ & 2536.648 & 7 & 39410.26 & $39725_{15 / 2}-79136^{\circ}{ }_{13 / 2}$ \\
\hline 2629.918 & 1 & 38012.66 & $65295^{\circ}-103308_{7 / 2}$ & 2534.759 & 9 & 39439.63 & $62240^{\circ}{ }_{11 / 2}-101680_{13 / 2}$ \\
\hline 2626.210 & 2 & 38066.33 & $62558_{11 / 2}^{\circ}-100625_{11 / 2}$ & 2531.925 & 7 & 39483.77 & $66148^{\circ}{ }_{13 / 2}-105632_{13 / 2}$ \\
\hline 2626.016 & 1 & 38069.14 & $68676_{5 / 2}^{\circ}-106745_{5 / 2}$ & 2530.464 & 9 & 39506.57 & $44903_{5 / 2}-84409_{3 / 2}^{\circ}$ \\
\hline 2624.624 & 1 & 38089.33 & $63576_{5 / 2}^{\circ}-101665_{5 / 2}$ & 2529.726 & 4 & 39518.09 & $63816_{11 / 2}^{\circ}-103335_{9 / 2}$ \\
\hline 2622.448 & 5 & 38120.94 & $68544_{9 / 2}^{\circ}-106665_{7 / 2}$ & 2529.430 & 2 & 39522.72 & $68331_{7 / 2}^{\circ}-107854_{9 / 2}^{0}$ \\
\hline 2619.706 & 3 & 38160.83 & $69138_{9 / 2}^{\circ}-107299_{7 / 2}$ & 2529.110 & 9 & 39527.72 & $65922^{\circ}{ }_{11 / 2}-105450_{11 / 2}$ \\
\hline 2619.162 & 1 & 38168.76 & $66735^{\circ}{ }_{13 / 2}-104904_{11 / 2}$ & 2528.330 & 2 & 39539.91 & $63768_{7 / 2}^{\circ}-103308_{7 / 2}$ \\
\hline 2618.891 & 2 & 38172.71 & $68492^{\circ}{ }_{7 / 2}-106665_{7 / 2}$ & 2526.636 & 1 & 39566.42 & $63768^{\circ}{ }_{7 / 2}-103335_{9 / 2}$ \\
\hline 2617.740 & 3 & 38189.49 & $62240^{\circ} 11 / 2-100430_{9 / 2}$ & 2525.123 & 8 & 39590.12 & $61357_{9 / 2}^{\circ}-100947_{9 / 2}$ \\
\hline 2616.047 & 1 & 38214.21 & $63232_{7 / 2}^{\circ}-101446_{7 / 2}$ & 2521.677 & 1 & 39644.22 & $65922^{\circ}{ }_{11 / 2}-105566_{9 / 2}$ \\
\hline 2613.377 & 3 & 38253.24 & $\begin{array}{l}62535_{9 / 2}^{\circ}-100788_{7 / 2} \\
68492^{\circ}{ }_{7 / 2}-106745_{5 / 2}\end{array}$ & 2521.021 & 7 & 39654.54 & $64150^{\circ}{ }_{11 / 2}-103805_{13 / 2}$ \\
\hline & & & & 2520.662 & 2 & 39660.18 & $64235_{9 / 2}^{\circ}-103895_{7 / 2}$ \\
\hline 2611.527 & 1 & 38280.34 & $68801^{\circ}{ }_{7 / 2}-107081_{9 / 2}$ & 2517.515 & 8 & 39709.76 & $65922^{\circ}{ }_{11 / 2}-105632_{13 / 2}$ \\
\hline 2610.351 & 8 & 38297.59 & $66301_{15 / 2}^{\circ}-104598_{13 / 2}$ & 2516.337 & 1 & 39728.35 & $61717^{\circ}{ }_{5 / 2}-101446_{7 / 2}$ \\
\hline 2606.515 & 5 & 38353.95 & $35024_{7 / 2}-73378^{\circ}{ }_{7 / 2}^{/ 2}$ & 2515.487 & 7 & 39741.77 & $63593_{9 / 2}^{\circ}-103335_{9 / 2}$ \\
\hline 2604.457 & 3 & 38384.25 & $62240_{11 / 2}^{\circ}-100625_{11 / 2}$ & 2509.243 & 7 & 39840.66 & $61605^{\circ} 7 / 2-101446_{7 / 2}$ \\
\hline 2603.320 & 2 & 38401.01 & $67049_{9 / 2}^{\circ}-105450_{11 / 2}$ & 2505.358 & 1 & 39902.44 & $37919_{7 / 2}-77822_{5 / 2}^{\circ}$ \\
\hline 2603.263 & 1 & 38401.86 & $64215_{13 / 2}^{\circ}-102617_{11 / 2}$ & 2503.391 & 5 & 39933.78 & $35828_{9 / 2}-75762_{9 / 2}^{\circ}$ \\
\hline 2602.446 & 2 & 38413.91 & $68331_{7 / 2}^{\circ}-106745_{5 / 2}$ & 2502.526 & 5 & 39947.59 & $61717_{5 / 2}^{\circ}-101665_{5 / 2}$ \\
\hline 2602.224 & 1 & 38417.19 & $37197_{3 / 2}-75614_{5 / 2}^{\circ}$ & 2499.968 & 10 & 39988.46 & $63816^{\circ}{ }_{11 / 2}-103805_{13 / 2}$ \\
\hline 2599.960 & 1 & 38450.64 & $66148_{13 / 2}^{\circ}-104598_{13 / 2}$ & 2499.686 & 6 & 39992.97 & $38701_{13 / 2}-78694_{11 / 2}^{\circ}$ \\
\hline 2595.448 & 1 & 38517.48 & $67049_{9 / 2}^{\circ}-105566_{9 / 2}$ & 2498.297 & 1 & 40015.20 & $68544_{9 / 2}^{\circ}-108559_{11 / 2}$ \\
\hline 2592.832 & 5 & 38556.34 & $68525_{11 / 2}^{\circ}-107081_{9 / 2}$ & 2497.143 & 2 & 40033.69 & $68525^{\circ} 11 / 2-108559_{11 / 2}$ \\
\hline 2592.424 & 2 & 38562.40 & $62062_{9 / 2}^{\circ}-100625_{11 / 2}$ & 2495.584 & 2 & 40058.70 & $67240^{\circ}{ }_{7 / 2}-107299_{7 / 2}$ \\
\hline 2590.248 & 3 & 38594.80 & $64235_{9 / 2}^{\circ}-102830_{9 / 2}$ & 2495.508 & 10 & 40059.92 & $61605^{\circ / 2}-101665_{5 / 2}$ \\
\hline 2589.900 & 4 & 38599.98 & $65295_{7 / 2}^{\circ}-103895_{7 / 2}$ & 2493.685 & 6 & 40089.20 & $61357_{9 / 2}^{\circ}-101446_{7 / 2}$ \\
\hline 2584.766 & 3 & 38676.65 & $65922_{11 / 2}^{\circ}-104598_{13 / 2}$ & 2491.326 & 6 & 40127.16 & $63768^{\circ}{ }_{7 / 2}-103895_{7 / 2}$ \\
\hline 2582.712 & 1 & 38707.40 & $68374_{9 / 2}^{\circ}-107081_{9 / 2}$ & 2487.750 & 6 & 40184.84 & $68374_{9 / 2}^{\circ}-108559_{11 / 2}$ \\
\hline 2577.866 & 2 & 38780.16 & $67965_{3 / 2}^{\circ}-106745_{5 / 2}$ & 2482.577 & 1 & 40268.57 & $60520^{\circ}{ }_{7 / 2}-100788_{7 / 2}$ \\
\hline 2576.922 & 3 & 38794.37 & $67870_{9 / 2}^{\circ}-106665_{7 / 2}$ & 2480.487 & 9 & 40302.49 & $63593_{9 / 2}^{\circ}-103895_{7 / 2}$ \\
\hline 2576.109 & 1 & 38806.61 & $68492_{7 / 2}^{\circ}-107299_{7 / 2}^{\circ}$ & 2475.946 & 1 & 40376.40 & $62240^{\circ} 11 / 2-102617_{11 / 2}$ \\
\hline 2574.917 & 7 & 38824.58 & $61605_{7 / 2}^{\circ}-100430_{9 / 2}$ & 2474.320 & 1 & 40402.94 & $44903_{5 / 2}-85306_{5 / 2}^{\circ}$ \\
\hline 2572.074 & 1 & 38867.49 & $68987^{\circ}{ }_{7 / 2}-107854_{9 / 2}$ & 2472.376 & 5 & 40434.70 & $38701_{13 / 2}-79136_{13 / 2}^{\circ}$ \\
\hline 2570.170 & 4 & 38896.28 & $66735_{13 / 2}^{\circ}-105632_{13 / 2}$ & 2469.796 & 1 & 40476.94 & $35137_{3 / 2}-75614_{5 / 2}^{\circ}$ \\
\hline 2565.796 & 1 & 38962.58 & $36652_{5 / 2}-75614_{5 / 2}^{\circ}$ & 2465.272 & 2 & 40551.21 & $60520^{\circ}{ }_{7 / 2}-101071_{5 / 2}$ \\
\hline 2565.346 & 1 & 38969.42 & $36670_{11 / 2}-75640^{\circ}{ }_{11 / 2}$ & 2462.895 & 10 & 40590.35 & $35024_{7 / 2}-75614_{5 / 2}^{\circ}$ \\
\hline
\end{tabular}


Table I. Newly classified lines of $\operatorname{Pr}$ III, $\lambda>2103 \AA$-Continued

\begin{tabular}{|c|c|c|c|c|c|c|c|}
\hline$\lambda_{\text {air }}$ & Intensity & $\begin{array}{c}\sigma \\
\left(\mathrm{cm}^{-1}\right)\end{array}$ & Classification & $\begin{array}{c}\lambda_{\text {air }} \\
\AA\end{array}$ & Intensity & $\begin{array}{c}\sigma \\
\left(\mathrm{cm}^{-1}\right)\end{array}$ & Classification \\
\hline 2460.719 & 10 & 40626.24 & $44679_{7 / 2}-85306_{5 / 2}^{\circ}$ & 2320.906 & 2 & 43073.39 & $62558_{11 / 2}^{\circ}-105632_{13 / 2}$ \\
\hline 2451.381 & 2 & 40780.98 & $60166_{9 / 2}^{\circ}-100947_{9 / 2}$ & 2317.199 & 9 & 43142.29 & $60166_{9 / 2}^{\circ}-103308_{7 / 2}$ \\
\hline 2449.908 & 4 & 40805.50 & $62678_{13 / 2}^{\circ}-103484_{15 / 2}$ & 2315.774 & 2 & 43168.84 & $60166_{9 / 2}^{\circ}-103335_{9 / 2}^{\circ}$ \\
\hline 2449.636 & 1 & 40810.03 & $37011_{5 / 2}-77822_{5 / 2}^{\circ}$ & 2310.248 & 3 & 43272.09 & $58174_{9 / 2}^{\circ}-101446_{7 / 2}$ \\
\hline 2442.697 & 1 & 40925.95 & $60520^{\circ}{ }_{7 / 2}^{\circ}-101446_{7 / 2}$ & 2309.386 & 1 & 43288.24 & $58158^{\circ}{ }_{7 / 2}-101446_{7 / 2}$ \\
\hline 2432.678 & 7 & 41094.49 & $34520_{5 / 2}-75614_{5 / 2}^{\circ}$ & 2308.670 & 5 & 43301.66 & $34520_{5 / 2}-77822_{5 / 2}^{\circ}$ \\
\hline 2431.260 & 8 & 41118.46 & $29263_{13 / 2}-70381_{13 / 2}^{\circ}$ & 2307.384 & 6 & 43325.79 & $62240_{11 / 2}^{\circ}-105566_{9 / 2}$ \\
\hline 2423.700 & 3 & 41246.71 & $62558^{\circ}{ }_{11 / 2}-103805_{13 / 2}$ & 2307.277 & 2 & 43327.80 & $40098_{5 / 2}-83426_{5 / 2}^{\circ}$ \\
\hline 2422.883 & 6 & 41260.61 & $60419^{\circ}{ }_{11 / 2}-101680_{13 / 2}$ & 2304.201 & 6 & 43385.64 & $60419_{11 / 2}^{\circ}-103805_{13 / 2}$ \\
\hline 2416.527 & 1 & 41369.13 & $65295^{\circ}{ }_{7 / 2}-106665_{7 / 2}$ & 2303.121 & 7 & 43405.98 & $41023_{7 / 2}-84430^{\circ}{ }_{7 / 2}$ \\
\hline 2384.757 & 5 & 41920.21 & $62678_{13 / 2}^{\circ}-104598_{13 / 2}$ & 2296.541 & 2 & 43530.34 & $63768_{7 / 2}^{\circ}-107299_{7 / 2}$ \\
\hline 2382.979 & 3 & 41951.49 & $61357_{9 / 2}^{\circ}-103308_{7 / 2}$ & 2295.856 & 4 & 43543.32 & $29835_{9 / 2}-73378^{\circ} 7 / 2$ \\
\hline 2382.588 & 6 & 41958.37 & $35863_{3 / 2}-77822_{5 / 2}^{\circ}$ & 2287.502 & 2 & 43702.33 & $64857^{\circ} 9 / 2-108559_{11 / 2}$ \\
\hline 2380.051 & 4 & 42003.09 & $65295^{\circ}{ }_{7 / 2}-107299_{7 / 2}$ & 2261.530 & 6 & 44204.17 & $40205_{3 / 2}-84409^{\circ}{ }_{3 / 2}$ \\
\hline 2378.867 & 6 & 42024.00 & $36670_{11 / 2}-78694_{11 / 2}^{\circ}$ & 2257.546 & 4 & 44282.17 & $41023_{7 / 2}-85306_{5 / 2}^{\circ}$ \\
\hline 2369.081 & 10 & 42197.57 & $60419^{\circ}{ }_{11 / 2}-102617_{11 / 2}$ & 2257.342 & $5 w$ & 44286.18 & $26095_{11 / 2}-70381^{\circ}{ }_{13 / 2}$ \\
\hline 2367.497 & 3 & 42225.80 & $62678_{13 / 2}^{\circ}-104904_{11 / 2}$ & 2251.445 & 8 & 44402.16 & $25979_{15 / 2}-70381_{13 / 2}^{\circ}$ \\
\hline 2365.796 & 8 & 42256.16 & $58174_{9 / 2}^{\circ}-100430_{9 / 2}$ & 2243.485 & $l w$ & 44559.69 & $39870_{9 / 2}-84430_{7 / 2}^{\circ}$ \\
\hline 2360.786 & 5 & 42345.83 & $62558_{11 / 2}^{\circ}-104904_{11 / 2}$ & 2238.560 & 6 & 44657.71 & $28720_{9 / 2}-73378_{7 / 2}^{\circ}$ \\
\hline 2357.627 & 3 & 42402.56 & $41023_{7 / 2}-83426_{5 / 2}^{\circ}$ & 2227.201 & 3 & 44885.45 & $28720_{9 / 2}-73606_{9 / 2}^{\circ}$ \\
\hline 2357.176 & 3 & 42410.67 & $60419^{\circ}{ }_{11 / 2}-102830_{9 / 2}$ & 2211.332 & 1 & 45207.52 & $40098_{5 / 2}-85306_{5 / 2}^{\circ}$ \\
\hline 2354.942 & 6 & 42450.90 & $58174_{9 / 2}^{\circ}-100625_{11 / 2}$ & 2208.939 & 6 & 45256.49 & $30505_{11 / 2}-75762_{9 / 2}^{\circ}$ \\
\hline 2354.128 & 2 & 42465.58 & $36670_{11 / 2}-79136_{13 / 2}^{\circ}$ & 2201.678 & $7 w$ & 45405.73 & $39024_{9 / 2}-84430_{7 / 2}^{\circ}$ \\
\hline 2353.942 & 6 & 42450.90 & $60166_{9 / 2}^{\circ}-102617_{11 / 2}$ & 2196.775 & 7 & 45507.06 & $37919_{7 / 2}-83426_{5 / 2}^{\circ}$ \\
\hline 2345.001 & 4 & 42630.85 & $58158_{7 / 2}^{\circ}-100788_{7 / 2}$ & 2176.676 & 3 & 45927.22 & $29835_{9 / 2}-75762_{9 / 2}^{\circ}$ \\
\hline 2337.295 & 2 & 42771.39 & $62678_{13 / 2}^{\circ}-105450_{11 / 2}$ & 2162.611 & 2 & 46225.88 & $27380_{11 / 2}-73606_{9 / 2}^{\circ}$ \\
\hline 2335.873 & 6 & 42797.43 & $35024_{7 / 2}-77822^{\circ}{ }_{5 / 2}$ & 2155.562 & 5 & 46377.03 & $29263_{13 / 2}-75640^{\circ}{ }_{11 / 2}$ \\
\hline 2332.129 & 1 & 42866.12 & $35828_{9 / 2}-78694^{\circ}{ }_{11 / 2}$ & 2148.203 & 1 & 46535.89 & $23442_{11 / 2}-69978^{\circ}{ }_{11 / 2}$ \\
\hline 2330.393 & 6 & 42898.06 & $64401_{5 / 2}^{\circ}-107299_{7 / 2}$ & 2135.942 & 2 & 46802.99 & $23175_{13 / 2}-69978^{\circ}{ }_{11 / 2}$ \\
\hline 2329.568 & 7 & 42913.25 & $58158_{7 / 2}^{\circ}-101071_{5 / 2}$ & & & & \\
\hline 2329.456 & 2 & 42915.31 & $60419^{\circ}{ }_{11 / 2}-103335_{9 / 2}$ & & & & \\
\hline 2325.016 & 2 & 42997.26 & $64857_{9 / 2}^{\circ}-107854_{9 / 2}$ & & & & \\
\hline 2324.807 & 1 & 43001.12 & $27380_{11 / 2}-70381^{\circ}{ }_{13 / 2}$ & & & & \\
\hline 2324.438 & 7 & 43007.95 & $62558_{11 / 2}^{\circ}-105566_{9 / 2}$ & & & & \\
\hline 2321.717 & 5 & 43058.35 & $28936_{3 / 2}-71994_{5 / 2}^{\circ}$ & & & & \\
\hline
\end{tabular}

\section{New Energy Levels}

The techniques for using electronic computers in the search for energy levels are now well-known. The method [9] by which the line-list is added to (or subtracted from) the known levels to obtain statistically significant numbers of repeating sums (or differences) was used here. The selection of real levels is based on the probability of the occurrence of a chain of repeating sums of a particular length and tolerance as well as the line intensity distribution in the chain. This method yields many energy levels, but there always remain a certain number which make few combinations (particularly levels of high $J$-value) and which must be sought by intensity criteria alone according to the appropriate selection rules, and predicted positions.

Most of the observed lines of Pr III with moderate to strong intensity in the vacuum ultraviolet range are due to transitions to the $4 f^{2} 5 d$ configuration. The highest density of lines occurs between 1000 and $1200 \AA$, the main region of the $4 f^{2} 5 d-4 f^{2} 5 f$ transition array. This is analogous to Ce III where the same region contained the $4 f 5 d-4 f 5 f$ array [3]. In both cases, the array is well isolated and easily accessible, so that a thorough description of it can be obtained. With these lines 74 levels of the $4 f^{2} 5 f$ configuration were found.

Designations in $L S$-coupling were assigned to these levels on the basis of relative line intensities. Although final designations are given in the $J_{1} l$ scheme in 
table II, the experimentally derived $L S$ names were important in relating the theoretical calculation of this configuration to the observed levels. The calculated $L S$ composition, while showing less purity than $J_{1} l$, gave single designations for many levels exceeding 50 percent. The largest $L S$ component for each level has been included in table VI.

A second region of high line-density appears from the beginning of table $\mathrm{X}$ to about $1800 \AA$. This is the short wavelength end of the $4 f^{2} 5 d-\left(4 f^{2} 6 p+5 d^{2} 4 f\right)$ transition array, which extends to about $2700 \AA$. Many of these lines were classified with the previously known levels. The tail of this array reaches to much shorter wavelengths due to the high-lying levels of $5 d^{2} 4 f$.

An extension of the high-level structure of even parity was made by using the longer wavelength linelist of reference 1 . By combining these lines with the $4 f^{2} 6 p$ levels, more levels in the region of the previously identified $4 f^{2} 6 d$ group were found. Calculations of the structure of the configurations $4 f^{2} 6 d$ and $4 f^{2} 7 s$ provided the means to distinguish the latter configuration from among these levels.

Several low levels of the $4 f^{2} 8 s$ configuration were found by adding the vacuum ultraviolet lines to the $4 f^{2} 6 p$ levels. They were identified by their predicted location (compared with Ce III, $4 f 8 s$ ), by their strong combinations with particular core terms of $4 f^{2} 6 p$, and by reasonable fitted values of the parameters $G^{3}(f s), \zeta(4 f)$ and $E^{3}\left(f^{2}\right)$.

A detailed investigation of the hfs of the $4 f^{2} 6 s$ configuration has been carried out by J. Reader and J. Sugar [10]. A by-product of this work was the discovery of the pair of levels based on the $4 f^{2}\left({ }^{3} \mathrm{P}_{2}\right)$ parent and the replacement of the level $\left\langle 4 f^{2}\left({ }^{1} \mathrm{D}_{2}\right)\right.$, $6 s, 5 / 2\rangle$.

The newly derived energy levels of Pr III are given in table II. Their designations result from calculations of the configurations in the purest coupling schemes, with radial parameters obtained by least squares fitting of linear energy formulas to the observed energy levels [11]. The results of these calculations are given in the sections which follow.

Designations of levels of the $4 f^{2} 5 f, 5 d^{2} 4 f$, and $4 f 5 d 6 s$ configurations in the $L S$-coupling scheme were made on the basis of relative strengths of the combinations with the $4 f^{2} 5 d$ terms. Later calculations of energy levels in this coupling scheme substantiated these assignments where the purity of the eigenvectors indicated a major $L S$ component for a level. The successful correlation of observed and calculated energy levels was largely due to these experimental $L S$ assignments.

The $4 f^{2} 6 d, 4 f^{2} 7 s$, and $4 f^{2} 8 s$ levels were designated in $J_{1 j}$-coupling according to the intensities of combinations with levels of $4 f^{2} 6 p$. In these transition arrays the selection rules $\Delta L_{1}=0, \Delta S_{1}=0$, and $\Delta J_{1}=0$ on parent levels are strongly obeyed. The $J_{1} j$-coupling designations given in table II for these configurations and for $4 f^{2} 6 s$ and $4 f^{2} 6 p$ contain the $4 f^{2}$ core level and the $j$-value of the outer electron.
TABLE II. New energy levels of Pr III

\begin{tabular}{|c|c|c|c|}
\hline Configuration & Designation & $J$ & Energy/hc $\left(\mathrm{cm}^{-1}\right)$ \\
\hline $4 f^{2} 6 s$ & $\begin{array}{l}\left({ }^{1} \mathrm{D}_{2}\right) \mathrm{l} / 2 \\
\left({ }^{3} \mathrm{P}_{1}\right) 1 / 2 \\
\left({ }^{3} \mathrm{P}_{2}\right) 1 / 2 \\
\left({ }^{3} \mathrm{P}_{2}\right) 1 / 2\end{array}$ & $\begin{array}{l}2 \frac{1}{2} \\
0 \frac{1}{2} \\
2 \frac{1}{2} \\
1 \frac{1}{2}\end{array}$ & $\begin{array}{r}\text { a } 45807.1 \\
50869.3 \\
51312.8 \\
52026.9\end{array}$ \\
\hline $5 d^{2} 4 f$ & $\begin{array}{l}\left({ }^{3} \mathrm{~F}\right)^{2} \mathrm{I}^{\circ} \\
\left({ }^{3} \mathrm{~F}\right)^{4} \mathrm{I}^{\circ} \\
\left({ }^{1} \mathrm{D}\right)^{2} \mathrm{H}^{\circ} \\
\left({ }^{3} \mathrm{P}\right)^{4} \mathrm{G}^{\circ} \\
\left({ }^{3} \mathrm{~F}\right)^{4} \mathrm{G}^{\circ} \\
\left({ }^{3} \mathrm{~F}\right)^{2} \mathrm{I}^{\circ} \\
\left({ }^{3} \mathrm{P}\right)^{4} \mathrm{G}^{\circ} \\
\left({ }^{3} \mathrm{P}\right)^{4} \mathrm{G}^{\circ} \\
\left({ }^{3} \mathrm{P}\right)^{2} \mathrm{D}^{\circ} \\
\left({ }^{1} \mathrm{D}\right)^{2} \mathrm{D}^{\circ} \\
\left({ }^{1} \mathrm{G}\right)^{2} \mathrm{H}^{\circ} \\
\left({ }^{1} \mathrm{G}\right)^{2} \mathrm{G}^{\circ} \\
\left({ }^{1} \mathrm{D}\right)^{2} \mathrm{G}^{\circ} \\
\left({ }^{3} \mathrm{P}\right)^{4} \mathrm{G}^{\circ} \\
\left({ }^{3} \mathrm{P}\right)^{4} \mathrm{D}^{\circ} \\
\left({ }^{3} \mathrm{P}\right)^{4} \mathrm{~F}^{\circ} \\
\left({ }^{3} \mathrm{P}\right)^{4} \mathrm{~F}^{\circ}\end{array}$ & $\begin{array}{l}5 \frac{1}{2} \\
7 \frac{1}{2} \\
5 \frac{1}{2} \\
2 \frac{1}{2} \\
5 \frac{1}{2} \\
6 \frac{1}{2} \\
4 \frac{1}{2} \\
3 \frac{1}{2} \\
1 \frac{1}{2} \\
2 \frac{1}{2} \\
4 \frac{1}{2} \\
3 \frac{1}{2} \\
4 \frac{1}{2} \\
5 \frac{1}{2} \\
2 \frac{1}{2} \\
1 \frac{1}{2} \\
3 \frac{1}{2}\end{array}$ & $\begin{array}{l}68238.12 \\
68305.1 \\
69408.51 \\
69681.6 \\
69978.08 \\
70381.48 \\
71021.1 \\
71385.6 \\
71501.0 \\
71994.81 \\
73029.9 \\
73378.42 \\
73606.17 \\
73609.1 \\
74105.2 \\
74463.7 \\
75294.0\end{array}$ \\
\hline $4 f^{2} 6 p$ & $\left({ }^{1} \mathrm{D}_{2}\right) 1 / 2^{\circ}$ & $2 \frac{1}{2}$ & 75614.81 \\
\hline $5 d^{2} 4 f$ & $\begin{array}{l}\left({ }^{3} \mathrm{~F}\right)^{2} \mathrm{H}^{\circ} \\
\left({ }^{1} \mathrm{G}\right)^{2} \mathrm{G}^{\circ} \\
\left({ }^{3} \mathrm{~F}\right)^{2} \mathrm{D}^{\circ} \\
\left({ }^{1} \mathrm{G}\right)^{2} \mathrm{~F}^{\circ} \\
\left({ }^{1} \mathrm{G}\right)^{2} \mathrm{~F}^{\circ} \\
\left({ }^{1} \mathrm{G}\right)^{2} \mathrm{I}^{\circ} \\
\left({ }^{1} \mathrm{G}\right)^{2} \mathrm{I}^{\circ}\end{array}$ & $\begin{array}{l}5 \frac{1}{2} \\
4 \frac{1}{2} \\
1 \frac{1}{2} \\
2 \frac{1}{2} \\
3 \frac{1}{2} \\
5 \frac{1}{2} \\
6 \frac{1}{2}\end{array}$ & $\begin{array}{l}75640.00 \\
75762.23 \\
76892.4 \\
77822.00 \\
78463.6 \\
78694.57 \\
79136.23\end{array}$ \\
\hline $4 f^{2} 6 p$ & $\left({ }^{1} \mathrm{D}_{2}\right) 3 / 2^{\circ}$ & $2 \frac{1}{2}$ & 79366.65 \\
\hline $5 d^{2} 4 f$ & $\left({ }^{1} \mathrm{G}\right)^{2} \mathrm{D}^{\circ}$ & $1 \frac{1}{2}$ & 82492.4 \\
\hline $4 f^{2} 6 p$ & $\begin{array}{l}\left({ }^{3} \mathrm{P}_{1}\right) 3 / 2^{\circ} \\
\left({ }^{3} \mathrm{P}_{1}\right) 3 / 2^{\circ} \\
\left({ }^{3} \mathrm{P}_{2}\right) 3 / 2^{\circ} \\
\left({ }^{3} \mathrm{P}_{2}\right) 3 / 2^{\circ}\end{array}$ & $\begin{array}{l}2 \frac{1}{2} \\
1 \frac{1}{2} \\
3 \frac{1}{2} \\
2 \frac{1}{2}\end{array}$ & $\begin{array}{l}83426.55 \\
84409.93 \\
84430.98 \\
85306.10\end{array}$ \\
\hline $4 f 5 d 6 s$ & $\begin{array}{l}\left({ }^{3} \mathrm{G}\right)^{4} \mathrm{G}^{\circ} \\
\left({ }^{3} \mathrm{G}\right)^{4} \mathrm{G}^{\circ} \\
\left({ }^{3} \mathrm{~F}\right)^{4} \mathrm{~F}^{\circ} \\
\left({ }^{3} \mathrm{G}\right)^{4} \mathrm{G}^{\circ} \\
\left({ }^{3} \mathrm{H}\right)^{2} \mathrm{H}^{\circ} \\
\left({ }^{3} \mathrm{G}\right)^{2} \mathrm{G}^{\circ}\end{array}$ & $\begin{array}{l}3 \frac{1}{2} \\
4 \frac{1}{2} \\
4 \frac{1}{2} \\
5 \frac{1}{2} \\
4 \frac{1}{2} \\
3 \frac{1}{2}\end{array}$ & $\begin{array}{l}87511.6 \\
88220.2 \\
88948.6 \\
90119.8 \\
90629.2 \\
92441.7\end{array}$ \\
\hline $5 d^{2} 4 f$ & $\left({ }^{1} \mathrm{~S}\right)^{2} \mathrm{~F}^{\circ}$ & $2 \frac{1}{2}$ & 92554.8 \\
\hline $4 f 5 d 6 s$ & $\left({ }^{3} \mathrm{H}\right)^{2} \mathrm{H}^{\circ}$ & $5 \frac{1}{2}$ & 93296.5 \\
\hline $5 d^{2} 4 f$ & $\left({ }^{1} \mathrm{~S}\right)^{2} \mathrm{~F}^{\circ}$ & $3 \frac{1}{2}$ & 93967.4 \\
\hline $4 f 5 d 6 s$ & $\begin{array}{l}\left({ }^{3} \mathrm{G}\right)^{2} \mathrm{G}^{\circ} \\
\left({ }^{1} \mathrm{~F}\right)^{2} \mathrm{~F}^{\circ}\end{array}$ & $\begin{array}{l}4 \frac{1}{2} \\
3 \frac{1}{2}\end{array}$ & $\begin{array}{l}95147.9 \\
96830.5\end{array}$ \\
\hline $4 f^{2} 6 d$ & $\begin{array}{l}\left({ }^{3} \mathrm{H}_{4}\right) 3 / 2 \\
\left({ }^{3} \mathrm{H}_{4}\right) 3 / 2 \\
\left({ }^{3} \mathrm{H}_{4}\right) 3 / 2 \\
\left({ }^{3} \mathrm{H}_{4}\right) 5 / 2 \\
\left({ }^{3} \mathrm{H}_{4}\right) 3 / 2 \\
\left({ }^{3} \mathrm{H}_{4}\right) 5 / 2 \\
\left({ }^{3} \mathrm{H}_{4}\right) 5 / 2 \\
\left({ }^{3} \mathrm{H}_{4}\right) 5 / 2 \\
\left({ }^{3} \mathrm{H}_{5}\right) 3 / 2 \\
\left({ }^{3} \mathrm{H}_{5}\right) 3 / 2 \\
\left({ }^{3} \mathrm{H}_{5}\right) 3 / 2 \\
\left({ }^{3} \mathrm{H}_{5}\right) 5 / 2 \\
\left({ }^{3} \mathrm{H}_{5}\right) 5 / 2 \\
\left({ }^{3} \mathrm{H}_{5}\right) 5 / 2 \\
\left({ }^{3} \mathrm{H}_{5}\right) 5 / 2\end{array}$ & $\begin{array}{l}4 \frac{1}{2} \\
5 \frac{1}{2} \\
3 \frac{1}{2} \\
4 \frac{1}{2} \\
2 \frac{1}{2} \\
3 \frac{1}{2} \\
2 \frac{1}{2} \\
6 \frac{1}{2} \\
5 \frac{1}{2} \\
4 \frac{1}{2} \\
3 \frac{1}{2} \\
4 \frac{1}{2} \\
7 \frac{1}{2} \\
6 \frac{1}{2} \\
3 \frac{1}{2}\end{array}$ & $\begin{array}{l}100430.29 \\
100625.04 \\
100788.95 \\
100947.18 \\
101071.43 \\
101446.27 \\
101665.58 \\
101680.38 \\
102617.24 \\
102830.43 \\
103308.53 \\
103335.06 \\
103484.19 \\
103805.38 \\
103895.83\end{array}$ \\
\hline
\end{tabular}




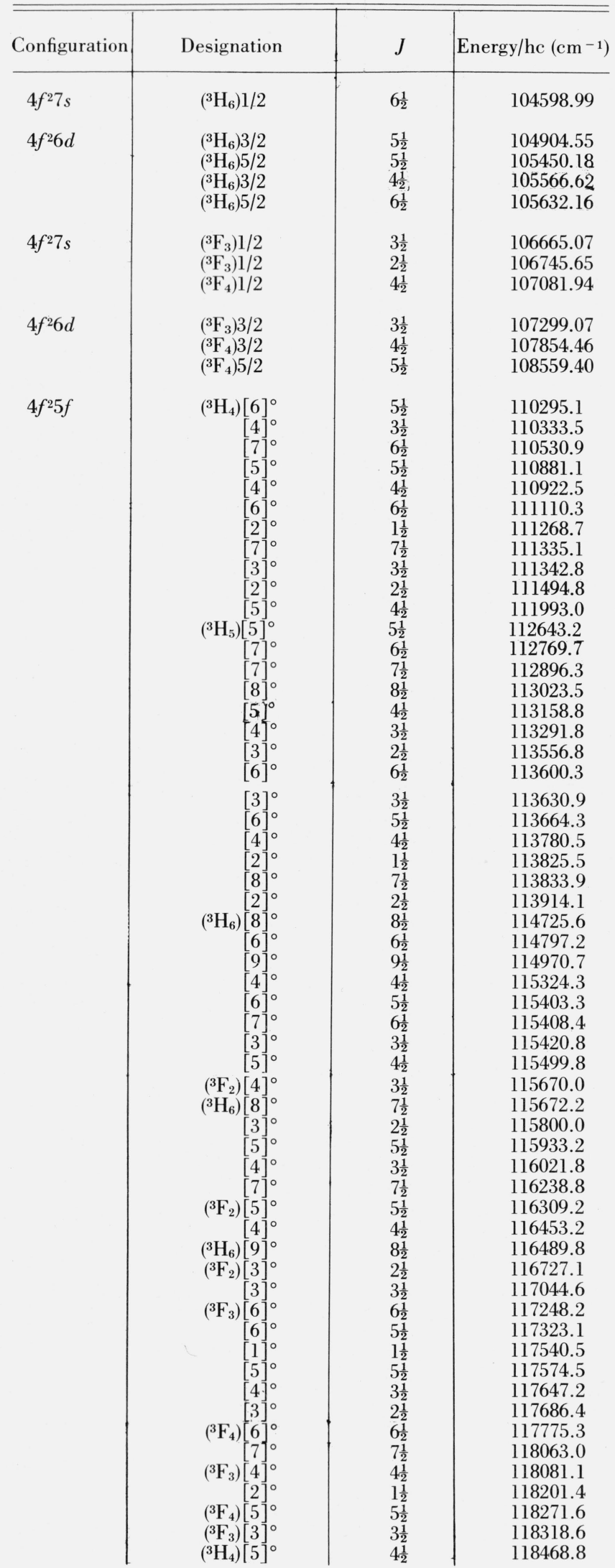

\begin{tabular}{|c|c|c|c|}
\hline Configuration & Designation & $J$ & Energy/hc $\left(\mathrm{cm}^{-1}\right)$ \\
\hline & $\begin{array}{r}{[7]^{\circ}} \\
{[5]^{\circ}} \\
\left({ }^{1} \mathrm{G}_{4}\right)[6]^{\circ} \\
{[5]^{\circ}} \\
{[7]^{\circ}} \\
{[5]^{\circ}} \\
{[7]^{\circ}} \\
{[6]^{\circ}} \\
\left({ }^{1} \mathrm{D}_{2}\right)[1]^{\circ} \\
{[5]^{\circ}} \\
{[5]^{\circ}} \\
{[4]^{\circ}} \\
{[4]^{\circ}} \\
\left({ }^{1} \mathrm{I}_{6}\right)[9]^{\circ} \\
{[9]^{\circ}} \\
{[8]^{\circ}} \\
{[8]^{\circ}}\end{array}$ & $\begin{array}{l}6 \frac{1}{2} \\
5 \frac{1}{2} \\
6 \frac{1}{2} \\
5 \frac{1}{2} \\
7 \frac{1}{2} \\
4 \frac{1}{2} \\
6 \frac{1}{2} \\
5 \frac{1}{2} \\
1 \frac{1}{2} \\
4 \frac{1}{2} \\
5 \frac{1}{2} \\
3 \frac{1}{2} \\
4 \frac{1}{2} \\
8 \frac{1}{2} \\
9 \frac{1}{2} \\
7 \frac{1}{2} \\
8 \frac{1}{2}\end{array}$ & $\begin{array}{l}118610.9 \\
118879.3 \\
120498.7 \\
121095.2 \\
121+19.2 \\
121382.6 \\
121431.2 \\
121532.5 \\
128214.2 \\
128352.8 \\
128381.6 \\
128453.2 \\
128568.6 \\
133194.3 \\
133242.3 \\
133352.2 \\
133373.0\end{array}$ \\
\hline $4 f^{2} 8 s$ & $\begin{array}{c}\left({ }^{3} \mathrm{H}_{4}\right) 1 / 2 \\
\left({ }^{3} \mathrm{H}_{5}\right) 1 / 2 \\
\left({ }^{3} \mathrm{H}_{5}\right) 1 / 2 \\
\left({ }^{3} \mathrm{H}_{6}\right) 1 / 2 \\
\left({ }^{3} \mathrm{H}_{6}\right) 1 / 2 \\
\left({ }^{3} \mathrm{~F}_{3}\right) 1 / 2 \\
\left({ }^{3} \mathrm{~F}_{4}\right) 1 / 2\end{array}$ & $\begin{array}{l}4 \frac{1}{2} \\
5 \frac{1}{2} \\
4 \frac{1}{2} \\
6 \frac{1}{2} \\
5 \frac{1}{2} \\
3 \frac{1}{2} \\
4 \frac{1}{2}\end{array}$ & $\begin{array}{l}129106.1 \\
131200.3 \\
131226.3 \\
133393.2 \\
133503.9 \\
135445.2 \\
135868.8\end{array}$ \\
\hline
\end{tabular}

${ }^{\text {a }}$ Level values are given to two decimal places when decived from wavelengths $>2100 \AA$ having no hfs.

\section{Theoretical Interpretation of the Observed Configurations}

For the calculation and diagonalization of energy matrices, computer programs written by Y. Bordarier and A. Carlier at Laboratoire Aimé Cotton, Orsay, France, were used. These programs evaluate the energy formulas given in terms of $n j$-coefficients, and compiled the output in the form of $J$-matrices which may then be diagonalized. The large library of matrices assembled at Hebrew University by G. Racah and his co-workers was made available to us by Z. Goldschmit, and is compatible with the above-mentioned programs.

The matrix library tape contains the configurations $f^{2} p$ and $f(d+s)^{2}$. For the present work they were combined with configuration interaction (utilizing the formulas for three-electron matrix elements calculated by Fano, Pratts, and Goldschmidt [12]) to study the configuration complex $4 f^{2} 6 p+5 d^{2} 4 f+4 f 5 d 6 s$. The matrices of $f^{2}(d+s)$ are also on the library tape, and were used in the study of $4 f^{2} 6 d, 4 f^{2} 7 s$, and $4 f^{2} 8 s$. The matrices of $f^{2} f^{\prime}$ were calculated manually by means of the Racah formalism [13] prior to the acquisition of these programs.

In the present paper, unreduced values for the Slater parameters are used. The convention of multiplying the coefficient martices by arbitrary factors to simplify denominators is unnecessary for computer calculations.

The notations for the parameters in tables III, V, VII, and IX have the following meaning: " $A$ " is an additive constant common to all levels of the configuration; $F^{k}\left(l, l^{\prime}\right)$ and $G^{k}\left(l, l^{\prime}\right)$ are the Slater radial integrals arising from the electrostatic interaction between the electrons $l$ and $l^{\prime} ; \zeta_{l}$ is the parameter of the spin-orbit 
TABLE III. Fitted parameter values and associated standard errors for the $4 \mathrm{f}^{2} 6 \mathrm{p}+5 \mathrm{~d}^{2} 4 \mathrm{f}+4 \mathrm{f} 5 \mathrm{~d} 6 \mathrm{~s}$ configurations of Pr III and corresponding parameters of Ce III and $\mathrm{Pr}$ IV in units of $\mathrm{cm}^{-1}$

\begin{tabular}{|c|c|c|c|}
\hline Parameters & Pr III & Ce III & Priv \\
\hline & $4 f^{2} 6 p$ & $4 f 6 p$ & $4 f^{2}$ \\
\hline 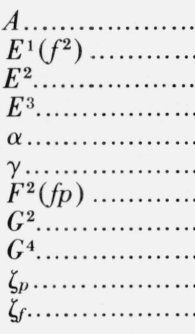 & $\begin{aligned} 67903 & \pm 90 \\
4984 & \pm 25 \\
23.1 & \pm 0.2 \\
486 & \pm 2 \\
28 & \pm 2 \\
-50 & \pm 9 \\
6075 & \pm 225 \\
1785 & \pm 140 \\
1531 & \pm 302 \\
2338 & \pm 24 \\
751 & \pm 10\end{aligned}$ & $\begin{array}{r}52001 \pm 62 \\
\\
\\
\\
5400 \pm 450 \\
2450 \pm 875 \\
945 \pm 284 \\
2155 \pm 33 \\
644 \pm 10\end{array}$ & $\begin{array}{c}5011 \pm 17 \\
23.1 \pm 0.1 \\
488 \pm 1 \\
24 \pm 1 \\
-49 \pm 6 \\
\\
760 \pm 6\end{array}$ \\
\hline & $5 d^{2} 4 f$ & $5 d^{2}$ & \\
\hline $\begin{array}{l}A \ldots \ldots \ldots \ldots \ldots \ldots \\
B\left(d^{2}\right) \ldots \ldots \ldots \ldots \ldots \\
C \ldots \ldots \ldots \ldots \ldots \ldots \\
F^{2}(f d) \ldots \ldots \ldots \ldots \\
F^{4} \ldots \ldots \ldots \ldots \ldots \ldots \\
G^{1} \ldots \ldots \ldots \ldots \ldots \ldots \\
G^{3} \ldots \ldots \ldots \ldots \ldots \ldots \\
G^{5} \ldots \ldots \ldots \ldots \ldots \ldots \\
\zeta_{d} \ldots \ldots \ldots \ldots \ldots \ldots \\
\zeta_{f} \ldots \ldots \ldots \ldots \ldots \ldots \\
E_{s} \ldots \ldots \ldots \ldots \ldots \ldots\end{array}$ & $\begin{aligned} 73137 & \pm 48 \\
406 & \pm 5 \\
2021 & \pm 21 \\
21000 & \pm 284 \\
15385 & \pm 431 \\
10080 & \pm 96 \\
13954 & \pm 665 \\
10825 & \pm 611 \\
946 & \pm 23 \\
838 & \pm 19 \\
483 & \pm 55\end{aligned}$ & $\begin{array}{c}46027 \pm 67 \\
442 \pm 3 \\
2006 \pm 111\end{array}$ & \\
\hline & $4 f 5 d 6 s$ & $5 d 6 s$ & \\
\hline $\begin{array}{l}A \ldots \ldots \ldots \ldots \ldots \\
F^{2}(f d) \ldots \ldots \ldots \ldots \\
F^{4} \ldots \ldots \ldots \ldots \ldots \\
G^{1} \ldots \ldots \ldots \ldots \ldots \ldots \\
G^{3} \ldots \ldots \ldots \ldots \ldots \ldots \\
G^{5} \ldots \ldots \ldots \ldots \ldots \ldots \\
G^{2}(d s) \ldots \ldots \ldots \ldots \\
G^{3}(f s) \ldots \ldots \ldots \ldots \\
\zeta_{d} \ldots \ldots \ldots \ldots \ldots \ldots \\
\zeta_{f} \ldots \ldots \ldots \ldots \ldots \ldots\end{array}$ & $\begin{array}{l}92316 \pm 156 \\
20790 \pm 1050 \\
15177 \text { Fixed } F^{2} / F^{4} \\
9905 \pm 476 \\
13167 \text { Fixed } G^{1} / G^{3} \\
10825 \text { Fixed } G^{1} / G^{5} \\
10125 \pm 410 \\
2100 \text { Fixed } \\
1035 \pm 66 \\
838 \text { Fixed }\end{array}$ & $\begin{array}{r}11125 \pm 705 \\
927 \pm \quad 28\end{array}$ & \\
\hline $\begin{array}{l}\text { Configuration } \\
\quad \text { interaction } \\
R^{1}\left(f p, d^{2}\right) \ldots \ldots \\
R^{3}\left(f p, d^{2}\right) \ldots \ldots \\
R^{1}(f p, d s) \ldots \ldots \\
R^{3}(f p, s d) \ldots \ldots \\
R^{2}(d d, d s) \ldots \ldots \\
R^{2}(f d, f s) \ldots \ldots \\
R^{3}(f d, s f) \ldots \ldots \\
.\end{array}$ & $\begin{array}{c}-1583 \pm 122 \\
1655 \pm 308 \\
6590 \pm 341 \\
0 \text { Fixed } \\
16940 \pm 621 \\
0 \text { Fixed } \\
0 \text { Fixed }\end{array}$ & $\begin{array}{c}3115 \pm 105 \\
0 \text { Fixed } \\
5355 \pm 730 \\
0 \text { Fixed } \\
15820 \pm 1295\end{array}$ & \\
\hline $\begin{array}{l}\text { rms error in } \\
\text { calculated } \\
\text { levels }\end{array}$ & $89 \mathrm{~cm}^{-1}$ & $47 \mathrm{~cm}^{-1}$ & \\
\hline
\end{tabular}

interaction for the electron $l ; E^{1}, E^{2}$, and $E^{3}$ are linear combinations of the Slater radial integrals defined by Racah [14] which arise from the electrostatic interaction within an $f^{n}$ shell; $\mathrm{B}$ and $\mathrm{C}$ are linear combinations of Slater integrals defined by Racah [13] for the $d^{n}$ shell; $\alpha$ and $\gamma$ are two-body effective interaction parameters acting within the $f^{n}$ shell which have the coefficients $L(L+1)$ and $12 g(U)$, respectively, where $L$ refers to the orbital angular momentum in the $f^{n}$ shell and
$g(U)$ are the eigenvalues of the Casimir operator $G\left(G_{2}\right)$ tabulated by Racah [14]; $E_{s}$ is the two-body effective interaction parameter for nonequivalent electrons proposed by Sack [20] and is used here for the $5 d^{2} 4 f$ configuration; $R^{k}$ are the radial integrals arising from configuration interaction.

\subsection{The $4 f^{2} 6 p+5 d^{2} 4 f+4 f 5 d 6 s$ Complex}

These three configurations are analogous to the Ce III group $4 f 6 p, 5 d^{2}$, and $5 d 6 s$ treated theoretically by Z. Goldschmidt [15]. She found strong mutual perturbations in Ce III, reporting large mixutres of terms of two configurations in several levels. This accounts for the poor results of Spector's calculation of $4 f 6 p$ alone [16]. The rms error in his calculated levels is $394 \mathrm{~cm}^{-1}$, while that obtained in reference 15 for the mixture of the three configurations is $47 \mathrm{~cm}^{-1}$.

Following the results in Ce III, I have treated the mixed complex of configurations $4 f^{2} 6 p, 5 d^{2} 4 f$, and $4 f 5 d 6 s$ in Pr III. Initial parameters for the first diagonalization of the energy matrices were obtained from the following sources for the $5 d^{2} 4 f$ and $4 f 5 d 6 s$ configurations:

\begin{tabular}{l|l|c}
\hline \hline Interaction & Source & Reference \\
& & \\
$d-d$ & Ce III $5 d^{2}$ & 15 \\
$d-s$ & Ce III $5 d 6 s$ & 15 \\
$f-s$ & Pr III $4 f^{2} 6 s$ & 19 \\
$d-f$ & Pr III $4 f^{2} 5 d$ & 17 \\
$\zeta_{d}\left(5 d^{2}\right)$ & Ce III $5 d^{2}$ & 15 \\
$\zeta_{d}(5 d)$ & Ce III $5 d 6 s$ & 15 \\
$\zeta_{f}$ & Pr IV $4 f 6 s$ & 18 \\
\hline \multicolumn{2}{l|}{} \\
\hline
\end{tabular}

The matrices for these configurations were diagonalized without configuration interaction to determine the correspondence with the observed levels. This was accomplished by means of the experimentally identified $L S$ composition of many of the levels. The parameters were then improved by least squares adjustment to fit the observed levels and further improved by several repetitions of these steps. Because of the small number of known levels of $4 f 5 d 6 \mathrm{~s}$, fixed ratios were assumed for $F^{2} / F^{4}, G^{1} / G^{3}$, and $G^{1} / G^{5}$ of the $f-d$ interaction as well as fixed values of $G^{3}(f, s)$ and $\zeta_{f}$. The refined parameter values then served as initial parameters for the first diagonalization with configuration interaction.

Spector has treated the $4 f^{2} 6 p$ configuration of $\operatorname{Pr}$ III theoretically [19] and obtained an rms error of 198 $\mathrm{cm}^{-1}$ for his calculated levels. His results served here for initial parameters of this configuration.

Initial values for the configuration interaction parameters $R^{1}\left(f p, d^{2}\right)$ between $4 f^{2} 6 p$ and $5 d^{2} 4 f, R^{1}(f p, d s)$ between $4 f^{2} 6 p$ and $4 f 5 d 6 s$, and $R^{2}\left(d^{2}, d s\right)$ between $5 d^{2} 4 f$ and $4 f \overline{5} d 6 s$ were taken from the Ce III results [15]. All other configuration interaction parameters were initially set equal to zero.

Several sequences of diagonalization and adjustment of the parameters were carried out to obtain conver- 
gence before attempting to evaluate the less sensitive interaction parameters. Then the parameters $R^{2}(f d, f s)$ and $R^{3}(f d, s f)$ which act between the $5 d^{2} 4 f$ and $4 f 5 d 6 s$ configurations, and $\mathrm{G}^{3}(f s)$ of the latter configuration were added. These were found to be undefinable in the least squares calculations (their standard errors exceeded their values) because too few levels of $4 f 5 d 6 \mathrm{~s}$ are known. They were therefore fixed at the following values:

$$
\begin{aligned}
R^{2}(f d, f s) & =R^{3}(f d, s f)=0 \\
G^{3}(f s) & =2100 \mathrm{~cm}^{-1} .
\end{aligned}
$$

Finally, values for $R^{3}\left(f p, d^{2}\right)$ and $R^{3}(f p, s d)$ were sought. The latter was undefinable and was therefore fixed at zero. The iterative fitting procedure was again brought to convergence, with an rms error of $119 \mathrm{~cm}^{-1}$ for the calculated levels.

Goldschmidt's success in utilizing the Sack [20] effective two-body interaction operators $E_{l} L(L+1)$ and $E_{s} S(S+1)$ acting on the final $L$ and $S$ of the levels of $4 f 5 d$ in Ce III [15] suggested their use for the $4 f^{2} 6 p$ and $5 d^{2} 4 f$ configurations of $\operatorname{Pr}$ III. For these configurations, following Sack, the operators are $E_{l}[L(L$ $\left.+1)-L_{c}\left(L_{c}+1\right)\right]$ and $E_{s}\left[S(S+1)-S_{c}\left(S_{c}+1\right)\right]$, where $L_{c}$ and $S_{c}$ refer to the $4 f^{2}$ or $5 d^{2}$ core terms. A well defined value was obtained only for $E_{s}$ of $5 d^{2} 4 f$. The addition of this parameter reduced the rms error to its final value of $89 \mathrm{~cm}^{-1}$.

In table III the final values for the parameters derived from the mixing of the three configurations are given. In all least squares calculations the ratios $F^{2} / F^{4}$. $G^{1} / G^{3}$, and $G^{1 /} / G^{5}$ of the $4 f 5 d 6 s$ configuration were fixed at the values taken by the corresponding parameters of $5 d^{2} 4 f$ in the preceding calculation. Also the parameter $\zeta_{f}$ of $4 f 5 d h s$ was required to be equal to $\zeta_{f}$ in $5 d^{2} 4 f$. The remaining free parameters common to these two configurations, namely $F^{2}$,
$G^{1}$, and $\zeta_{d}$, took nearly equal values in both configurations. It is interesting to note that they are nearly equal to the corresponding parameters of the $4 f 5 d$ configuration [18] of Pr IV.

Included in table III are the corresponding parameters of Ce III evaluated by Goldschmidt [15] and the parameters of the $4 f^{2}$ configuration of $\operatorname{Pr}$ IV [21] included for comparison with $4 f^{2} 6 p$ core interactions.

Table IV contains all the calculated levels of the three configurations, all the experimental levels assigned to these configurations, and the squares of the components of the eigenvectors of the calculated levels (their percentage composition). A maximum of three components is given for each level, but less are shown when the sum represents 90 percent or more of the composition. Where a level contains 20 percent or more of the eigenvectors of two configurations, both are indicated in the column labeled "configuration" by -means of an " $X$ ".

The highest purity of eigenvectors for $4 f^{2} 6 p$ is of course obtained in $J_{1} j$-coupling because of the large value of $\zeta_{p}$ and the small electrostatic interaction between the $f$ and $p$ electrons, The designation of the energy levels in this scheme gives the $4 f^{2}$ core level in parentheses followed by the $j$ of the $6 p$ electron $(1 / 2$ or $3 / 2)$.

The coupling is much less pure in $5 d^{2} 4 f$. Here the electrostatic interactions within the $5 d^{2}$ shell and between $5 d$ and $4 f$ are both strong. Therefore, no preferred order of coupling of electrons occurs. The basis states are calculated in an $L S$ scheme in which the $d$ electrons are first coupled and the $f$ electron is then added. In table IV the $5 d^{2}$ core term is given in parentheses followed by the final $L S$ term. The large values of $\zeta(5 d)$ and $\zeta(4 f)$ give rise to intermediate coupling. I transformed the elgenvectors to the $\left(d^{2}\right) J_{1}(f) j$ scheme and found higher purity for a few levels, but the average purity for the configuration is lower than in the $L S$ scheme.

TABLE IV. Calculated energy levels and compositions of the mixed $4 \mathrm{f}^{2} 6 \mathrm{p}, 5 \mathrm{~d}^{2} 4 \mathrm{f}$, and $4 \mathrm{f} 5 \mathrm{~d} 6 \mathrm{~s}$ configurations of Pr III.

The $4 f^{2} 6 p$ levels are designated in $J_{1} j$-coupling. The levels of $5 d^{2} 4 f$ and $4 f 5 d 6$ s are designated in $L . S$-couplirg. with these of $4 f 5 d 6 s$ distinguished by the symbol ${ }^{*}$. Levels attributed to two configurations contain 20 percent or more of each

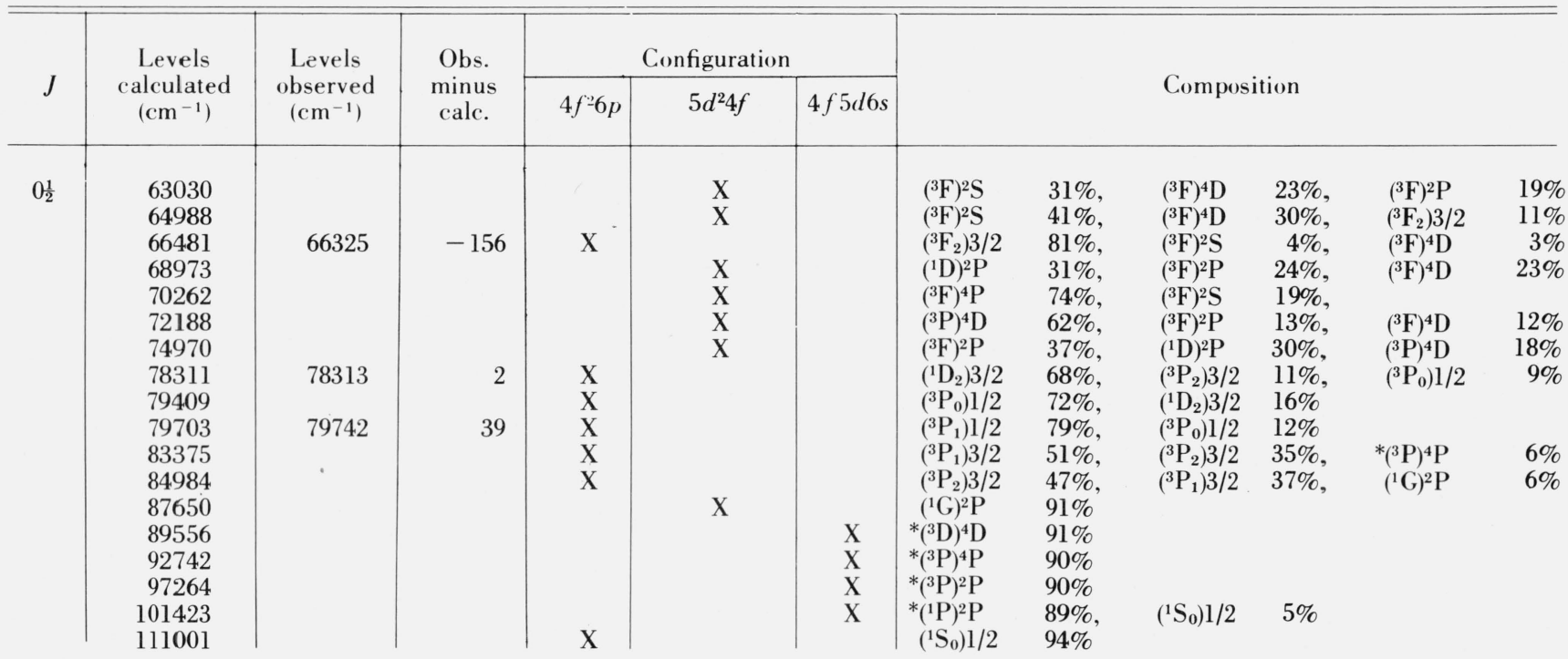


TABLE IV. Calculated energy levels and compositions of the mixed $4 \mathrm{f}^{2} 6 \mathrm{p}, 5 \mathrm{~d}^{2} 4 \mathrm{f}$, and $4 \mathrm{f} 5 \mathrm{~d} 6 \mathrm{~s}$ configurations of Pr III. - Continued

The $4 f^{2} 6 p$ levels are designated in $J_{1} j$-coupling. The levels of $5 d^{2} 4 f$ and $4 f 5 d 6 s$ are designated in $L S$-coupling, with those of $4 f 5 d 6 s$ distinguished by the symbol ${ }^{*}$. Levels attributed to two configurations contain 20 percent or more of each

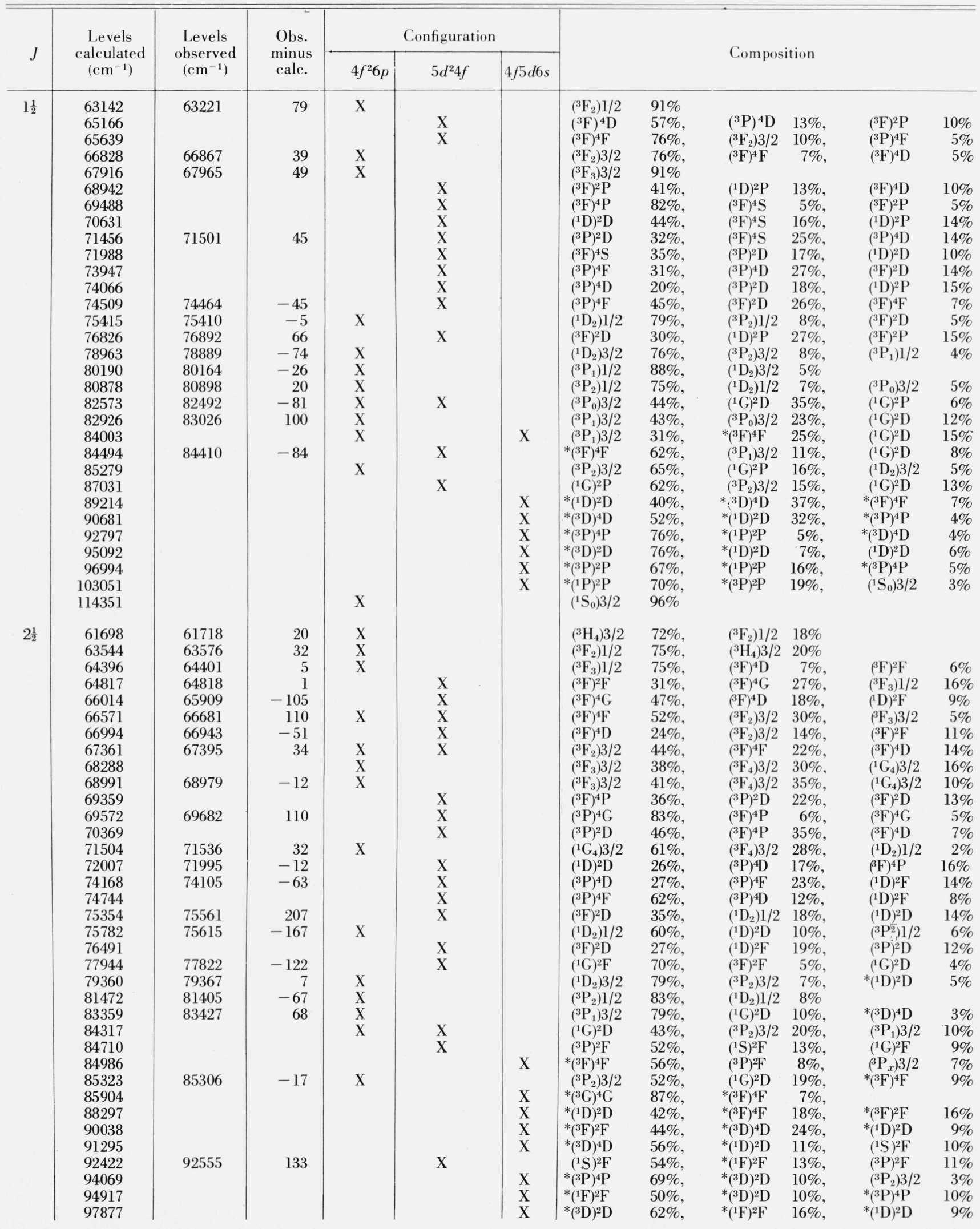


TABLE IV. Calculated energy levels and compositions of the mixed $4 \mathrm{f}^{2} 6 \mathrm{p}, 5 \mathrm{~d}^{2} 4 \mathrm{f}$, and $4 \mathrm{f} 5 \mathrm{~d} 6 \mathrm{~s}$ configurations of Pr III. - Continued

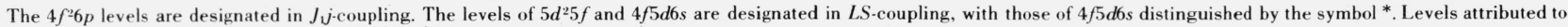
two configurations contain 20 percent or more of eac

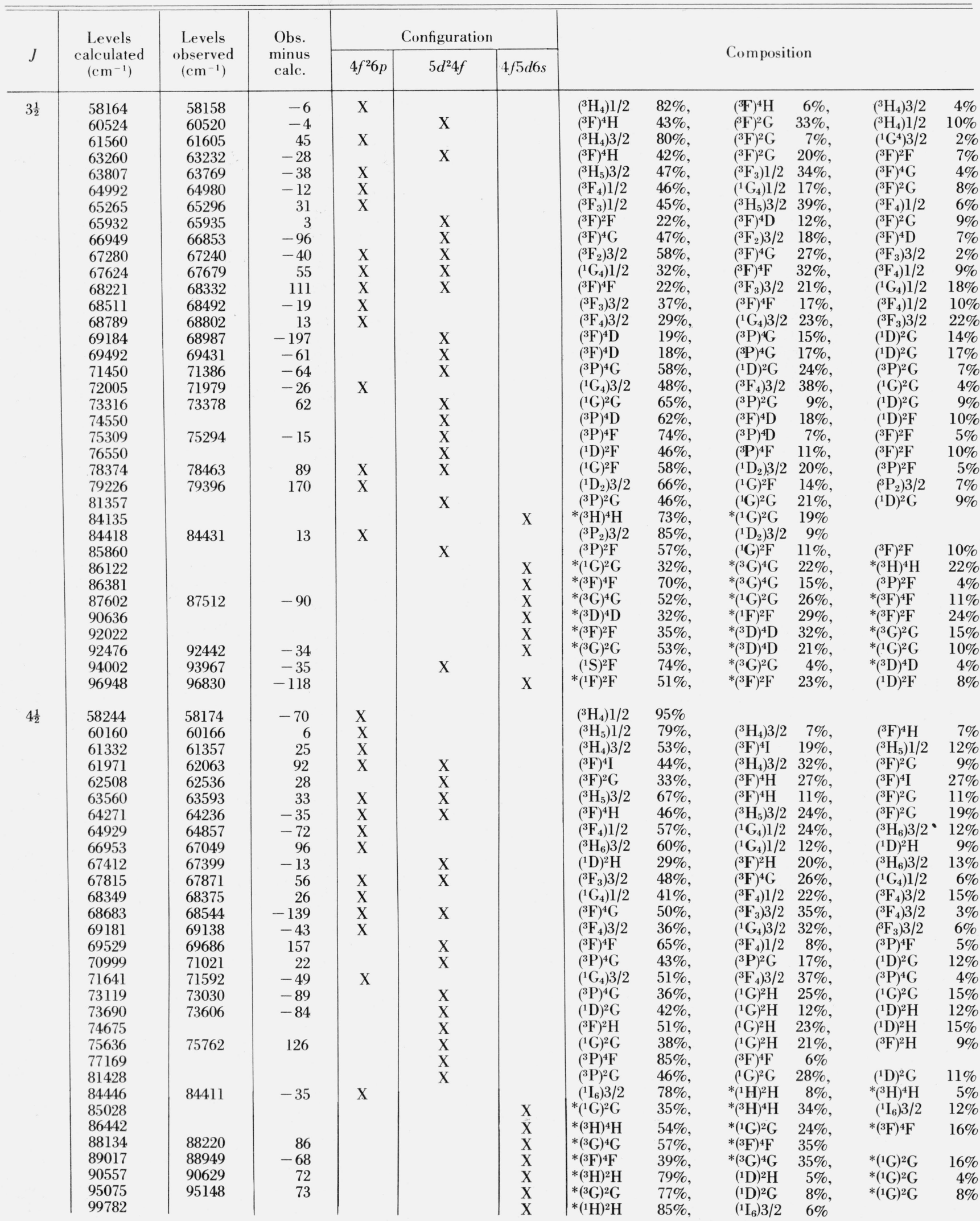


TABLE IV. Calculated energy levels and compositions of the mixed $4 \mathrm{f}^{2} 6 \mathrm{p}, 5 \mathrm{~d}^{2} 4 \mathrm{f}$, and $4 \mathrm{f} 5 \mathrm{~d} 6 \mathrm{~s}$ configurations of Pr III. - Continued

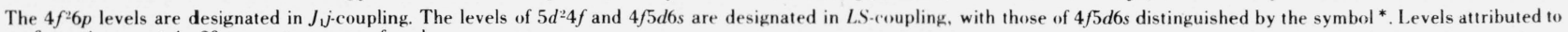
two configurations contain 20 percent or more of each

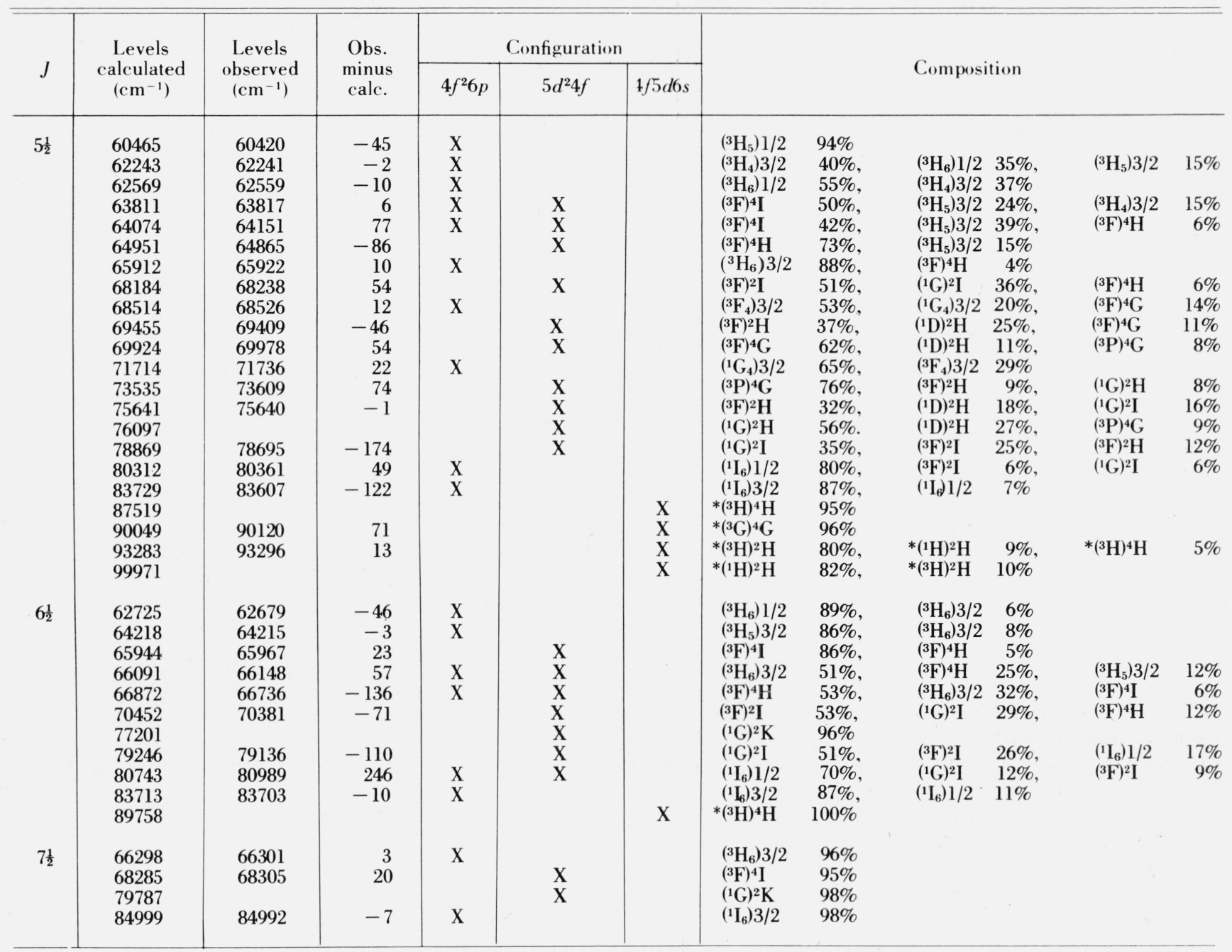

The $5 d^{2} 4 f$ configuration is illustrated in figure 1 . The observed levels are represented by solid lines and the calculated positions of unknown levels are given as dashed lines. The term designations represent the major components, although in many cases these are less than 50 percent. The identity of a unique major component in some cases is impossible. In spite of the intermediate coupling, the low-lying quartets exhibit a regularity in their structure characteristic of $L S$-coupling. This is also true of the equally complex $4 f^{2} 5 d$ configuration of the same ion [1]. Judd has shown that this structure arises from the near equality of $\zeta(4 f)$ and $\zeta(5 d)$, which results in nearly null nondiagonal matrix elements between terms of maximum multiplicity [22]. The structure of the $\left({ }^{3} \mathrm{~F}\right)^{4} \mathrm{H}^{0}$ term is distorted by the strong mixture with $\left({ }^{3} F\right)^{2} G^{0}$.
The coupling in $4 f 5 d 6 s$ is $L S$, but not very pure because of the large spin-orbit interactions. The basis states were constructed by first coupling the $f$ and $d$ electrons to form parent terms and then adding the $s$ electron. If more levels had been found, it would probably have been possible to define parameters $E_{l}$ and $E_{s}$ for this configuration since they have been essential to other configurations of Pr III and Ce III containing both $4 f$ and $5 d$ electrons.

\subsection{The $4 f^{2} 5 f$ Configuration}

This is a well-isolated configuration which is quite amenable to individual treatment. The correspond- 
TABLE V. Fitted parameter values and associated standard errors for the $4 \mathrm{f}^{2} 5 \mathrm{f}$ configuration of $\mathrm{Pr}$ III and corresponding parameters of Ce III in units of $\mathrm{cm}^{-1}$

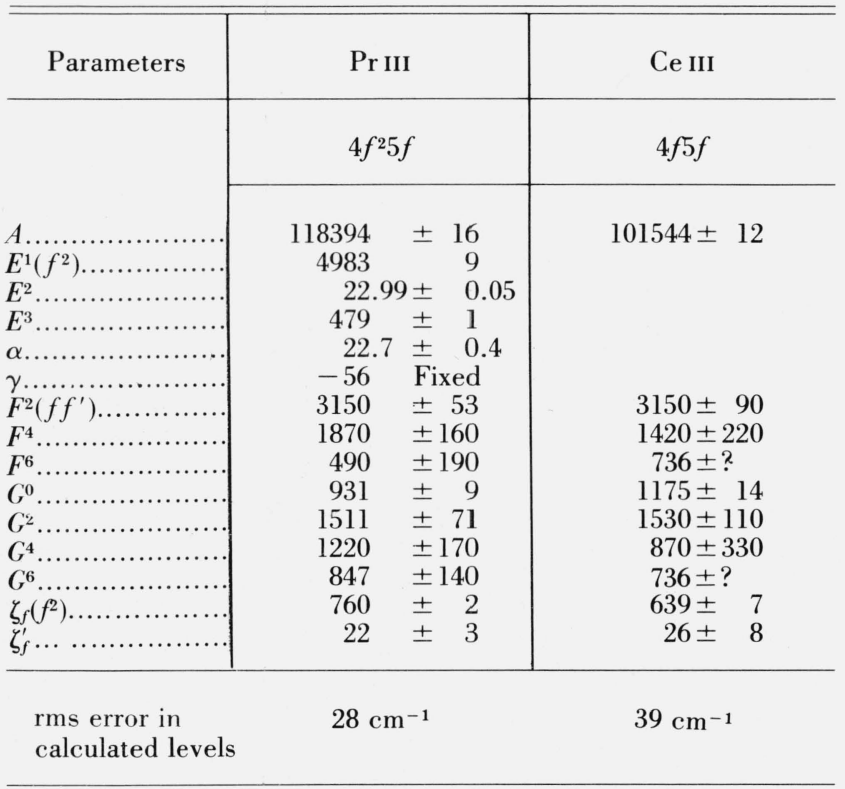

ing configuration $4 f 5 f$ of Ce III reported in reference 3 was treated theoretically by Spector [16], who obtained an rms error in the level predictions of $39 \mathrm{~cm}^{-1}$.

As was found in the Ce III work, the highest purity of eigenvectors results from the use of the $J_{1} l$-coupling scheme. However, due to the large value of the exchange parameter $G^{0}\left(f f^{\prime}\right)$, substantial $L S$-components are obtained when the calculation is carried out in the $L S$-scheme. Analogous to Ce III, this condition permitted the experimental assignment of many $L S$ terms on the basis of line intensities due to transitions to the $L S$-coupled $4 f^{2} 5 d$ configuration. These $L S$ designations were essential in establishing the correspondence between the observed and calculated levels.

Initial parameter values were obtained from the $4 f^{2}$ configuration of $\operatorname{Pr}$ IV for the $4 f^{2}$ core interactions and from Spector's results in Ce III for the $f-f^{\prime}$ interaction as well as for $\zeta(5 f)$.

Because no levels based on $4 f^{2}\left({ }^{3} \mathrm{P}\right)$ or $\left({ }^{1} \mathrm{~S}\right)$ are known only 4 electrostatic core parameters could be fit to the 5 observed core terms. Therefore the "effective" interaction parameter $\gamma$ was fixed at $-56 \mathrm{~cm}^{-1}$, the value obtained by $\mathrm{S}$. Feneuille and N. PelletierAllard [23] in a recent calculation of $4 f^{2}(6 s+5 d)$ of Pr III. The free parameters did not change significantly from their initial values.

All observed levels of odd parity in this region were fitted to the $4 f^{2} 5 f$ configuration. The final $\mathrm{rms}$ error in the calculated level positions was $28 \mathrm{~cm}^{-1}$. The resulting parameters are given in table $\mathrm{V}$ along with the corresponding ones of $4 f 5 f$ of Ce III.

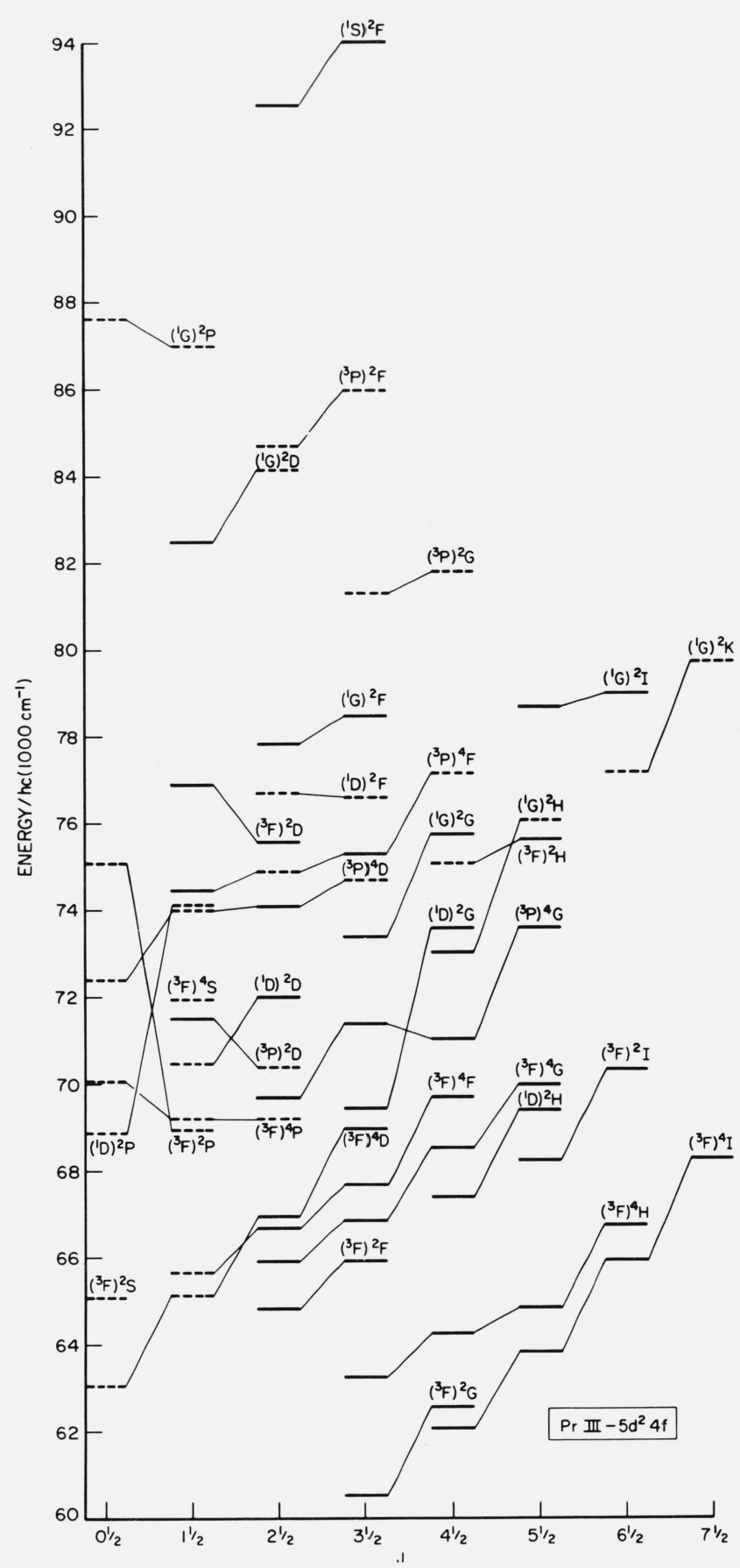

Figure 1. Energy levels of the $5 \mathrm{~d}^{2} 4 \mathrm{f}$ configuration of $\mathrm{Pr}$ III. Levels not observed are represented by dashed lines at their calculated positions.

The calculated and observed energy levels. and eigenvectors of $4 f^{2} 5 f$ in $J_{1} l$-coupling are given in table VI. The designations show the $4 f^{2}$ core level followed by the quantum number $K=\left(J_{1}+l\right)$ in square brackets. Because of the importance of the $L S$-coupling designations in the theoretical analysis they are included in a column containing the largest component in this scheme. 
TABLE VI. Calculated energy levels and compositions of the $4 \mathrm{f}^{2} 5 \mathrm{f}$ configuration of Pr III.

Designations are in $J_{1} l$-coupling

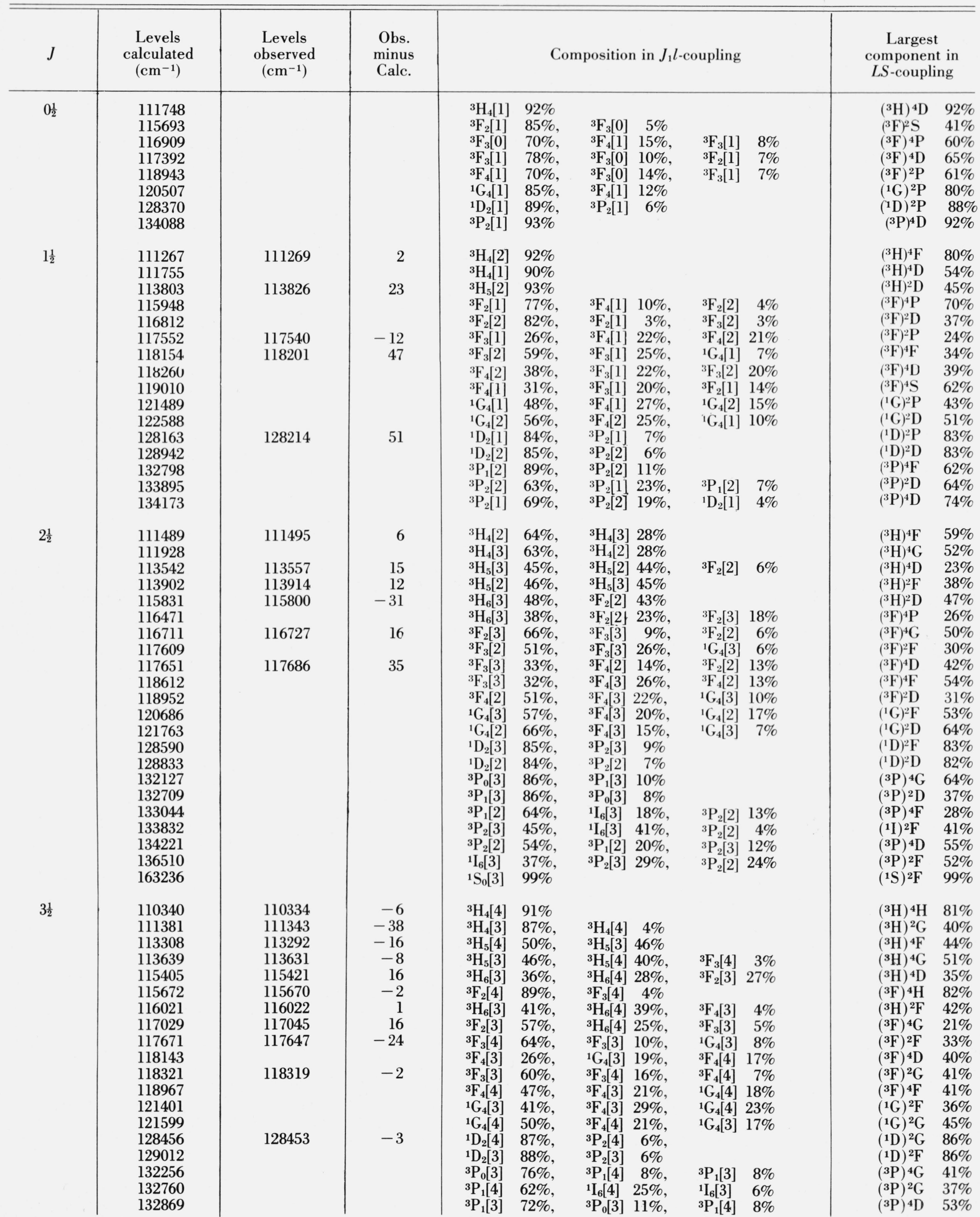


TABLE VI: Calculated energy levels and compositions of the $4 \mathrm{f}^{2} 5 \mathrm{f}$ configuration of $\operatorname{Pr}$ III. - Continued

Designations are in $J_{1} l$-coupling

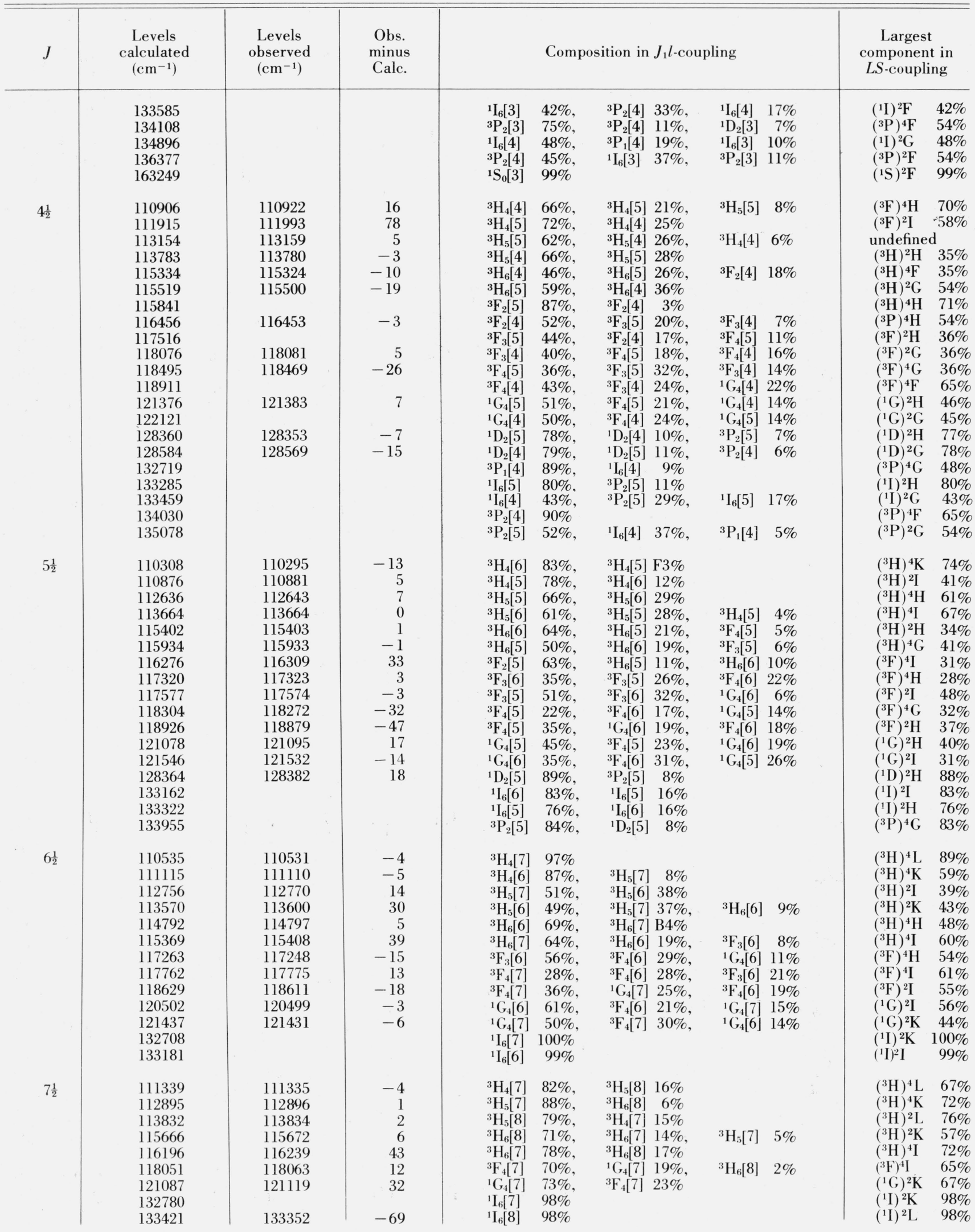


TABLE VI. Calculated energy levels and compositions of the $4 \mathrm{f}^{2} 5 \mathrm{f}$ configuration of $\mathrm{Pr}$ III. - Continued

Designations are in $J_{1} l$-coupling

\begin{tabular}{|c|c|c|c|c|c|}
\hline$J$ & $\begin{array}{l}\text { Levels } \\
\text { calculated } \\
\left(\mathrm{cm}^{-1}\right)\end{array}$ & $\begin{array}{c}\text { Levels } \\
\text { observed } \\
\left(\mathrm{cm}^{-1}\right)\end{array}$ & $\begin{array}{l}\text { Obs. } \\
\text { minus } \\
\text { Calc. }\end{array}$ & Composition in $J_{1} l$-coupling & $\begin{array}{c}\text { Largest } \\
\text { component in } \\
L S \text {-coupling }\end{array}$ \\
\hline $8 \frac{1}{2}$ & $\begin{array}{l}113026 \\
114733 \\
116497 \\
133120 \\
133438\end{array}$ & $\begin{array}{l}113024 \\
114726 \\
116490 \\
133194 \\
133373\end{array}$ & $\begin{array}{r}-2 \\
-7 \\
-7 \\
74 \\
-65\end{array}$ & $\begin{array}{llll}{ }^{3} \mathrm{H}_{5}[8] & 94 \% & & \\
{ }^{3} \mathrm{H}_{6}[8] & 95 \% & & \\
{ }^{3} \mathrm{H}_{6}[9] & 89 \%, & { }^{3} \mathrm{H}_{5}[8] & 6 \% \\
{ }^{1} \mathrm{I}_{6}[9] & 98 \% & & \\
{ }^{1} \mathrm{I}_{6}[8] & 97 \% & & \end{array}$ & $\begin{array}{ll}\left({ }^{3} \mathrm{H}\right)^{4} \mathrm{~L} & 94 \% \\
\left({ }^{3} \mathrm{H}\right)^{4} \mathrm{~K} & 95 \% \\
\left({ }^{3} \mathrm{H}\right)^{2} \mathrm{~L} & 89 \% \\
\left({ }^{1} \mathrm{I}\right)^{2} \mathrm{M} & 98 \% \\
\left({ }^{1} \mathrm{I}\right)^{2} \mathrm{~L} & 97 \%\end{array}$ \\
\hline $9 \frac{1}{2}$ & $\begin{array}{l}114978 \\
133191\end{array}$ & $\begin{array}{l}114971 \\
133242\end{array}$ & $\begin{array}{r}-7 \\
51\end{array}$ & $\begin{array}{ll}{ }^{3} \mathrm{H}_{6}[9] & 100 \% \\
{ }^{1} I_{6}[9] & 100 \%\end{array}$ & $\begin{array}{ll}\left({ }^{3} \mathrm{H}\right){ }^{4} \mathrm{~L} & 100 \% \\
\left({ }^{1} \mathrm{I}\right)^{2} \mathrm{M} & 100 \%\end{array}$ \\
\hline
\end{tabular}

The energy level structure of $4 f^{2} 5 f$ is shown in figure 2 in $J_{1} l$-coupling. Pairs of levels of equal $J_{1}$ and $K$ are connected and the $4 f^{2}$ core is indicated. The experimentally derived levels are drawn with solid lines, and those not found are drawn with dashed lines at their calculated positions. By comparing this structure with that of $4 f 5 f$ of Ce III shown in figure 4 of reference 3 , we note a decrease in the pair splittings in $\mathrm{Pr}$ III, indicating a trend with increasing $\mathrm{Z}$ to purer $J_{1} l$ coupling. The electrostatic parameter $G^{0}\left(f f^{\prime}\right)$ has decreased by 20 percent from its value in Ce III while $\mathrm{F}^{2}\left(f f^{\prime}\right)$ remains unchanged.

\subsection{The $4 f^{2} 6 d$ and $4 f^{2} 7 s$ Configurations}

Levels of both of these configurations were given in ref. 2, but were all designated as $4 f^{2} 6 d$. They were derived from transitions to $4 f^{2} 6 p$. No distinction between configurations was evident from relative line intensities.

The present analysis of this transition array revealed 26 more levels belonging to the upper two configurations. A clue as to the designation of these levels is the fact that nearly all observed transitions from a given upper level has the same $4 f^{2}$ core level of $4 f^{2} 6 p$ in common. This arises from the condition that both the upper and lower configurations exhibit good $J$ j-coupling.

The two configurations $4 f^{2} 6 d$ and $4 f^{2} 7 s$ were expected to overlap because of the arrangement of the corresponding Ce III configurations $4 f 6 d$ and $4 f 7 s$. To unravel them, I calculated their energy levels using the parameters of Ce III for the $f$-d and $f$-s interactions, and compared the result with the known levels. It was then possible to recognize the level groupings in the two configurations.

For both configurations, levels based only on the two core levels ${ }^{3} \mathrm{H}$ and ${ }^{3} \mathrm{~F}$ are known. Therefore, only one core electrostatic parameter, namely $E^{3}$, could be determined. The ratios $E^{1} / E^{3}$ and $E^{1} / E^{2}$ were fixed at the values 10.3 and 216 , respectively. These ratios are nearly equal in the configurations [17, 23] $4 f^{3}, 4 f^{2}(5 d+6 s)$, and $4 f^{2} 6 p$ (table III of present work) of $\operatorname{Pr}$ III, and $4 f^{2}$ of $\operatorname{Pr}$ IV(see table III). The parameters $\alpha$ and $\gamma$ of the $4 f^{2}$ core were fixed at the values found in $4 f^{2} 6 s$ of Pr III [23].

The least squares adjustment of the $4 f-6 d$ and $4 f-7 s$ interaction parameters produced the well-defined values given in tables VII and IX. The corresponding parameters of $4 f 6 d$ in Ce III are also given. A diagonalization with these final parameters provided the calculated levels and eigenvectors in $J_{1} j$-coupling shown in table VIII for the $4 f^{2}\left({ }^{3} \mathrm{H},{ }^{3} \mathrm{~F}\right) 6 d$ levels. A complete listing of the calculated results is not given because of the small number of known levels. The eigenvectors were also calculated in the $J_{1} l$-coupling scheme. The overall purity of levels was found to be lower than in $J_{1} j$, as is the case in Ce III for $4 f 6 d$ [16].

A diagram of the configurations $4 f^{2}\left({ }^{3} \mathrm{H},{ }^{3} \mathrm{~F}\right) 6 d$ and $7 s$ is given in figure 3 . As in figures 1 and 2 , observed levels are given as solid lines while those not yet located are represented by dashed lines at their calculated positions. Levels are connected which are based on the same $J_{1}$ core level.

TABLE VII. Fitted parameter values and associated standard errors for the $4 \mathrm{f}^{2} 6 \mathrm{~d}$ configuration of PrIII and corresponding parameters of Ce III in units of $\mathrm{cm}^{-1}$.

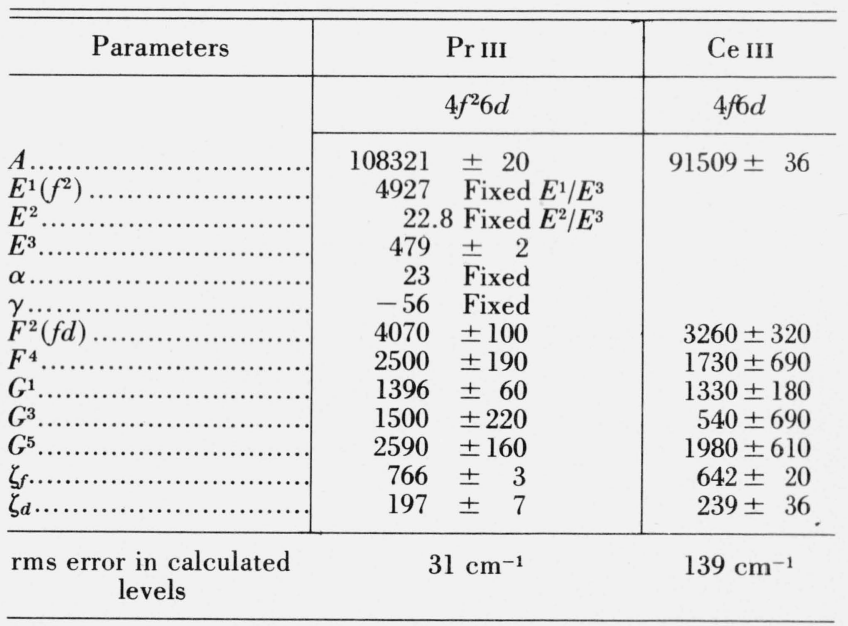




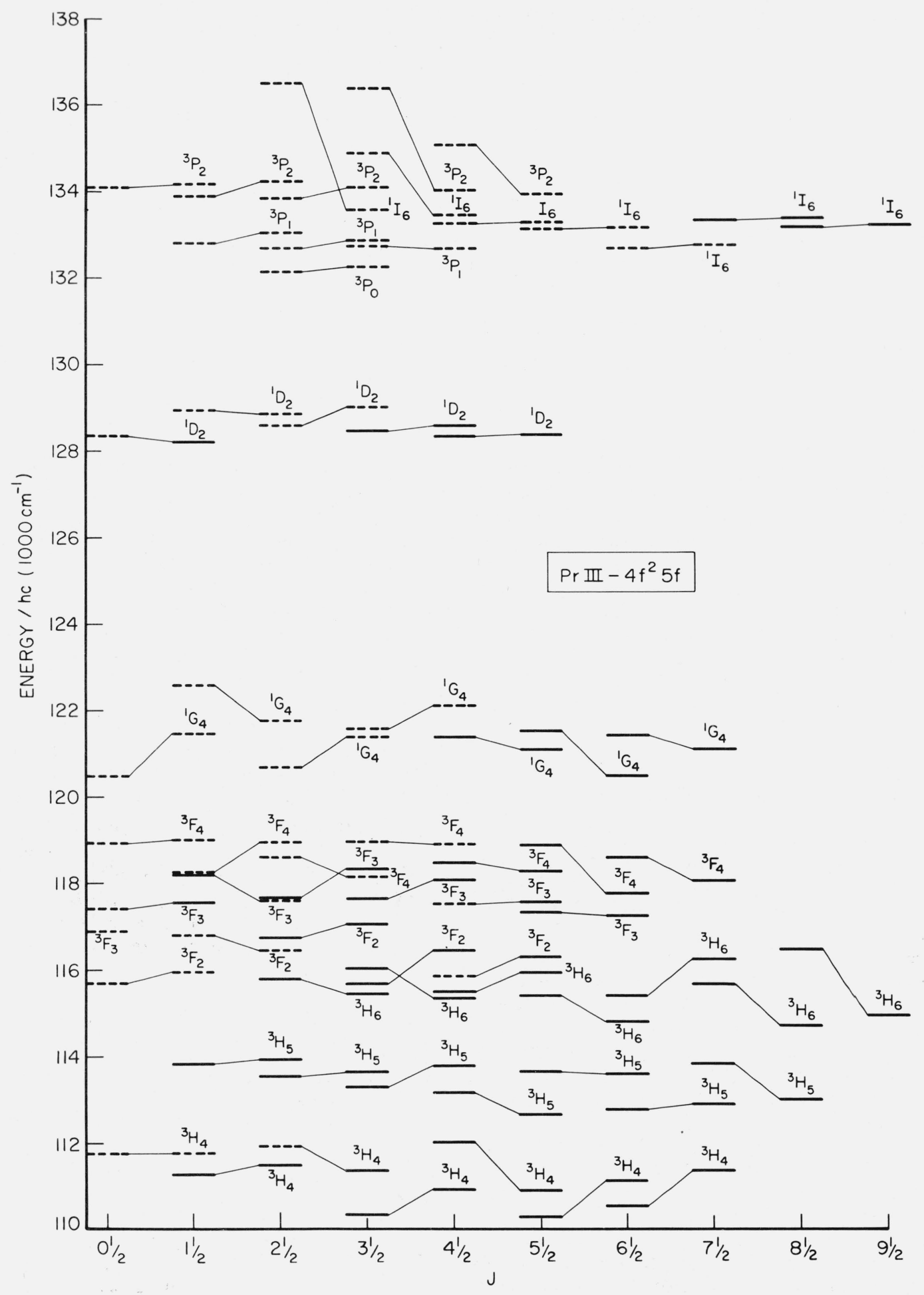

FIGURE 2. Energy levels of the $4 \mathrm{f}^{2} 5 \mathrm{f}$ configuration of $\operatorname{Pr}$ III.

Pairs of levels of identical $4 f^{2}$ core and quantum number $K$ in the $J_{1} l$-coupling scheme are connected. Levels not observed are represented by dashed lines at their calculated positions. 
TABLE VIII. Calculated energy levels and compositions of the $4 \mathrm{f}^{2} 6 \mathrm{~d}$ configuration of $\operatorname{Pr}$ III. Designations are in $J_{1} j$-coupling. Only levels built primarily on $4 f^{2}\left({ }^{3} \mathrm{H}\right)$ and $4 f^{2}\left({ }^{3} \mathrm{~F}\right)$ core levels are given.

\begin{tabular}{|c|c|c|c|c|c|c|c|c|c|}
\hline$J$ & $\begin{array}{c}\text { Levels } \\
\text { calculated }\end{array}$ & $\begin{array}{l}\text { Levels } \\
\text { observed }\end{array}$ & $\begin{array}{l}\text { Obs. } \\
\text { minus }\end{array}$ & \multicolumn{6}{|c|}{ Composition in $J_{1} j$-coupling } \\
\hline $0^{1 / 2}$ & $\begin{array}{l}105740 \\
105973 \\
107684\end{array}$ & & & $\begin{array}{l}\left({ }^{3} \mathrm{~F}_{2}\right) 3 / 2 \\
\left({ }^{3} \mathrm{~F}_{2}\right) 5 / 2 \\
\left({ }^{3} \mathrm{~F}_{3}\right) 5 / 2\end{array}$ & $\begin{array}{l}92 \% \\
93 \% \\
99 \%\end{array}$ & & & & \\
\hline $1 \frac{1 / 2}{2}$ & $\begin{array}{l}101658 \\
106059 \\
106154 \\
107120 \\
107844 \\
108345\end{array}$ & & & $\begin{array}{l}\left({ }^{3} \mathrm{H}_{4}\right) 5 / 2 \\
\left({ }^{3} \mathrm{~F}_{2}\right) 3 / 2 \\
\left({ }^{3} \mathrm{~F}_{2}\right) 5 / 2 \\
\left({ }^{3} \mathrm{~F}_{3}\right) 3 / 2 \\
\left({ }^{3} \mathrm{~F}_{3}\right) 5 / 2 \\
\left({ }^{3} \mathrm{~F}_{4}\right) 5 / 2\end{array}$ & $\begin{array}{l}97 \% \\
92 \% \\
94 \% \\
96 \% \\
82 \% \\
56 \%\end{array}$ & $\begin{array}{l}\left({ }^{3} \mathrm{~F}_{4}\right) 5 / 2 \\
\left({ }^{1} \mathrm{G}_{4}\right) 5 / 2\end{array}$ & $\begin{array}{l}7 \%, \\
31 \%,\end{array}$ & $\begin{array}{l}\left({ }^{3} \mathbf{F}_{3}\right) 3 / 2 \\
\left({ }^{3} \mathbf{F}_{3}\right) 5 / 2\end{array}$ & $\begin{array}{r}4 \% \\
10 \%\end{array}$ \\
\hline $2^{1 / 2}$ & $\begin{array}{l}101071 \\
101715 \\
104106 \\
105741 \\
106369 \\
107280 \\
107600 \\
107799 \\
108809\end{array}$ & $\begin{array}{l}101071 \\
101666\end{array}$ & $\begin{array}{r}0 \\
-49\end{array}$ & $\begin{array}{l}\left({ }^{3} \mathrm{H}_{4}\right) 3 / 2 \\
\left({ }^{3} \mathrm{H}_{4}\right) 5 / 2 \\
\left({ }^{3} \mathrm{H}_{5}\right) 5 / 2 \\
\left({ }^{3} \mathrm{~F}_{2}\right) 3 / 2 \\
\left({ }^{3} \mathrm{~F}_{2}\right) 5 / 2 \\
\left({ }^{3} \mathrm{~F}_{3}\right) 3 / 2 \\
\left({ }^{3} \mathrm{~F}_{4}\right) 3 / 2 \\
\left({ }^{3} \mathrm{~F}_{3}\right) 5 / 2 \\
\left({ }^{3} \mathrm{~F}_{4}\right) 5 / 2\end{array}$ & $\begin{array}{l}50 \%, \\
52 \%, \\
94 \% \\
85 \%, \\
87 \%, \\
83 \%, \\
62 \%, \\
75 \%, \\
52 \%,\end{array}$ & $\begin{array}{l}\left({ }^{3} \mathrm{H}_{4}\right) 5 / 2 \\
\left({ }^{3} \mathrm{H}_{4}\right) 3 / 2 \\
\\
\left({ }^{3} \mathrm{~F}_{2}\right) 5 / 2 \\
\left({ }^{3} \mathrm{~F}_{2}\right) 3 / 2 \\
\left({ }^{3} \mathrm{~F}_{3}\right) 5 / 2 \\
\left({ }^{1} \mathrm{G}_{4}\right) 3 / 2 \\
\left({ }^{3} \mathrm{~F}_{3}\right) 3 / 2 \\
\left({ }^{1} \mathrm{G}_{4}\right) 5 / 2\end{array}$ & $\begin{array}{c}45 \% \\
43 \% \\
8 \% \\
6 \% \\
6 \%, \\
26 \%, \\
8 \%, \\
25 \%,\end{array}$ & $\begin{array}{l}\left({ }^{3} \mathrm{~F}_{4}\right) 5 / 2 \\
\left({ }^{3} \mathrm{~F}_{3}\right) 3 / 2 \\
\left({ }^{1} \mathrm{G}_{4}\right) 5 / 2 \\
\left({ }^{3} \mathrm{~F}_{3}\right) 5 / 2\end{array}$ & $\begin{array}{r}4 \% \\
6 \% \\
7 \% \\
14 \%\end{array}$ \\
\hline $3^{1 / 2}$ & $\begin{array}{l}100783 \\
101477 \\
103361 \\
103955 \\
105514 \\
106433 \\
106496 \\
107328 \\
107890 \\
108173 \\
108305\end{array}$ & $\begin{array}{l}100789 \\
101446 \\
103309 \\
103896\end{array}$ & $\begin{array}{r}6 \\
-31 \\
-52 \\
-59 \\
\\
\\
-29\end{array}$ & $\begin{array}{l}\left({ }^{3} \mathrm{H}_{4}\right) 3 / 2 \\
\left({ }^{3} \mathrm{H}_{4}\right) 5 / 2 \\
\left({ }^{3} \mathrm{H}_{5}\right) 3 / 2 \\
\left({ }^{3} \mathrm{H}_{5}\right) 5 / 2 \\
\left({ }^{3} \mathrm{~F}_{2}\right) 3 / 2 \\
\left({ }^{3} \mathrm{~F}_{2}\right) 5 / 2 \\
\left({ }^{3} \mathrm{H}_{6}\right) 5 / 2 \\
\left({ }^{3} \mathrm{~F}_{3}\right) 3 / 2 \\
\left({ }^{3} \mathrm{~F}_{4}\right) 3 / 2 \\
\left({ }^{3} \mathrm{~F}_{3}\right) 5 / 2 \\
\left({ }^{1} \mathrm{G}_{4}\right) 5 / 2\end{array}$ & $\begin{array}{l}65 \%, \\
64 \%, \\
93 \% \\
95 \% \\
89 \%, \\
77 \%, \\
86 \%, \\
64 \%, \\
34 \%, \\
54 \%, \\
30 \%,\end{array}$ & $\begin{array}{l}\left({ }^{3} \mathrm{H}_{4}\right) 5 / 2 \\
\left({ }^{3} \mathrm{H}_{4}\right) 3 / 2 \\
\\
\left({ }^{3} \mathrm{~F}_{2}\right) 5 / 2 \\
\left({ }^{3} \mathrm{~F}_{3}\right) 3 / 2 \\
\left({ }^{3} \mathrm{~F}_{3}\right) 3 / 2 \\
\left({ }^{3} \mathrm{~F}_{4}\right) 3 / 2 \\
\left({ }^{3} \mathrm{~F}_{4}\right) 5 / 2 \\
\left({ }^{3} \mathrm{~F}_{3}\right) 3 / 2 \\
\left({ }^{3} \mathrm{~F}_{4}\right) 5 / 2\end{array}$ & $\begin{array}{c}31 \% \\
28 \% \\
\\
7 \% \\
13 \% \\
5 \% \\
8 \%, \\
26 \% \\
12 \% \\
27 \%\end{array}$ & $\begin{array}{l}\left({ }^{3} \mathrm{~F}_{3}\right) 5 / 2 \\
\left({ }^{1} \mathrm{G}_{4}\right) 3 / 2 \\
\left({ }^{3} \mathrm{~F}_{4}\right) 3 / 2 \\
\left({ }^{3} \mathrm{~F}_{3}\right) 5 / 2\end{array}$ & $\begin{array}{r}8 \% \\
19 \% \\
11 \% \\
25 \%\end{array}$ \\
\hline $4^{1 / 2}$ & $\begin{array}{l}100415 \\
100954 \\
102853 \\
103327 \\
105519 \\
106245 \\
106346 \\
107190 \\
107819 \\
107872 \\
108600\end{array}$ & $\begin{array}{l}100430 \\
100947 \\
102830 \\
103335 \\
105567\end{array}$ & $\begin{array}{r}15 \\
-7 \\
-23 \\
8 \\
48\end{array}$ & $\begin{array}{l}\left({ }^{3} \mathrm{H}_{4}\right) 3 / 2 \\
\left({ }^{3} \mathrm{H}_{4}\right) 5 / 2 \\
\left({ }^{3} \mathrm{H}_{5}\right) 3 / 2 \\
\left({ }^{3} \mathrm{H}_{5}\right) 5 / 2 \\
\left({ }^{3} \mathrm{H}_{6}\right) 3 / 2 \\
\left({ }^{3} \mathrm{~F}_{2}\right) 5 / 2 \\
\left({ }^{3} \mathrm{H}_{6}\right) 5 / 2 \\
\left({ }^{3} \mathrm{~F}_{3}\right) 3 / 2 \\
\left({ }^{3} \mathrm{~F}_{3}\right) 5 / 2 \\
\left({ }^{3} \mathrm{~F}_{4}\right) 3 / 2 \\
\left({ }^{3} \mathrm{~F}_{4}\right) 5 / 2\end{array}$ & $\begin{array}{l}96 \%, \\
94 \% \\
79 \% \\
74 \% \\
96 \% \\
61 \%, \\
69 \% \\
54 \% \\
83 \% \\
32 \% \\
42 \%\end{array}$ & $\begin{array}{l}\left({ }^{3} \mathrm{H}_{5}\right) 5 / 2 \\
\left({ }^{3} \mathrm{H}_{5}\right) 3 / 2 \\
\\
\left({ }^{3} \mathrm{H}_{6}\right) 5 / 2 \\
\left({ }^{3} \mathrm{~F}_{2}\right) 5 / 2 \\
\left({ }^{3} \mathrm{~F}_{4}\right) 3 / 2 \\
\left({ }^{1} \mathrm{G}_{4}\right) 3 / 2 \\
\left({ }^{3} \mathrm{~F}_{3}\right) 3 / 2 \\
\left({ }^{1} \mathrm{G}_{4}\right) 5 / 2\end{array}$ & $\begin{array}{l}18 \%, \\
18 \% \\
25 \%, \\
19 \%, \\
8 \% \\
20 \%, \\
33 \%,\end{array}$ & $\begin{array}{l}\left.{ }^{3} \mathrm{~F}_{3}\right) 3 / 2 \\
\left({ }^{1} \mathrm{G}_{4}\right) 3 / 2 \\
\left({ }^{1} \mathrm{G}_{4}\right) 3 / 2 \\
\left({ }^{3} \mathrm{~F}_{3}\right) 3 / 2\end{array}$ & $\begin{array}{r} \\
8 \% \\
12 \% \\
13 \% \\
9 \%\end{array}$ \\
\hline $5 \frac{1 / 2}{2}$ & $\begin{array}{l}100617 \\
101165 \\
102639 \\
103336 \\
104924 \\
105458 \\
107403 \\
107720 \\
108527\end{array}$ & $\begin{array}{l}100625 \\
101165 \\
102617 \\
103344 \\
104905 \\
105450\end{array}$ & $\begin{array}{r}8 \\
0 \\
-22 \\
8 \\
-19 \\
-8\end{array}$ & $\begin{array}{l}\left({ }^{3} \mathrm{H}_{4}\right) 3 / 2 \\
\left({ }^{3} \mathrm{H}_{4}\right) 5 / 2 \\
\left({ }^{3} \mathrm{H}_{5}\right) 3 / 2 \\
\left({ }^{3} \mathrm{H}_{5}\right) 5 / 2 \\
\left({ }^{3} \mathrm{H}_{6}\right) 3 / 2 \\
\left({ }^{3} \mathrm{H}_{6}\right) 5 / 2 \\
\left({ }^{3} \mathrm{~F}_{3}\right) 5 / 2 \\
\left({ }^{3} \mathrm{~F}_{4}\right) 3 / 2 \\
\left({ }^{3} \mathrm{~F}_{4}\right) 5 / 2\end{array}$ & $\begin{array}{l}96 \% \\
94 \% \\
95 \% \\
96 \% \\
93 \% \\
82 \% \\
67 \% \\
29 \% \\
42 \%\end{array}$ & $\begin{array}{l}\left({ }^{3} \mathrm{~F}_{4}\right) 3 / 2 \\
\left({ }^{3} \mathrm{~F}_{4}\right) 5 / 2 \\
\left({ }^{1} \mathrm{G}_{4}\right) 5 / 2\end{array}$ & $\begin{array}{l}24 \% \\
20 \% \\
21 \%\end{array}$ & $\begin{array}{l}\left({ }^{3} \mathrm{~F}_{3}\right) 5 / 2 \\
\left({ }^{1} \mathrm{G}_{4}\right) 3 / 2\end{array}$ & $\begin{array}{l}19 \% \\
15 \%\end{array}$ \\
\hline $6^{1 / 2}$ & $\begin{array}{l}101667 \\
102988 \\
103764 \\
105020 \\
105644 \\
107979\end{array}$ & $\begin{array}{l}101680 \\
102982 \\
103805 \\
105019 \\
105632\end{array}$ & $\begin{array}{r}13 \\
-6 \\
41 \\
-1 \\
-12\end{array}$ & $\begin{array}{l}\left({ }^{3} \mathrm{H}_{4}\right) 5 / 2 \\
\left({ }^{3} \mathrm{H}_{5}\right) 3 / 2 \\
\left({ }^{3} \mathrm{H}_{5}\right) 5 / 2 \\
\left({ }^{3} \mathrm{H}_{6}\right) 3 / 2 \\
\left({ }^{3} \mathrm{H}_{6}\right) 5 / 2 \\
\left({ }^{3} \mathrm{~F}_{4}\right) 5 / 2\end{array}$ & $\begin{array}{l}84 \%, \\
51 \%, \\
48 \%, \\
86 \%, \\
85 \%, \\
70 \%,\end{array}$ & $\begin{array}{l}\left({ }^{3} \mathrm{H}_{5}\right) 3 / 2 \\
\left({ }^{3} \mathrm{H}_{5}\right) 5 / 2 \\
\left({ }^{3} \mathrm{H}_{5}\right) 3 / 2 \\
\left({ }^{3} \mathrm{H}_{6}\right) 5 / 2 \\
\left({ }^{3} \mathrm{H}_{6}\right) 3 / 2 \\
\left({ }^{1} \mathrm{G}_{4}\right) 5 / 2\end{array}$ & $\begin{array}{l}10 \% \\
47 \% \\
39 \% \\
13 \% \\
12 \% \\
27 \%\end{array}$ & & \\
\hline $71 / 2$ & $\begin{array}{l}103488 \\
105080 \\
106356\end{array}$ & $\begin{array}{l}103484 \\
105050\end{array}$ & $\begin{array}{r}-4 \\
-30\end{array}$ & $\begin{array}{l}\left({ }^{3} \mathrm{H}_{5}\right) 5 / 2 \\
\left({ }^{3} \mathrm{H}_{6}\right) 5 / 2 \\
\left({ }^{3} \mathrm{H}_{6}\right) 3 / 2\end{array}$ & $\begin{array}{l}95 \% \\
57 \%, \\
54 \%,\end{array}$ & $\begin{array}{l}\left({ }^{3} \mathrm{H}_{6}\right) 3 / 2 \\
\left({ }^{3} \mathrm{H}_{6}\right) 5 / 2\end{array}$ & $\begin{array}{l}42 \% \\
41 \%\end{array}$ & & \\
\hline $81 / 2$ & 105513 & & & $\left({ }^{3} \mathrm{H}_{6}\right) 5 / 2$ & $100 \%$ & & & & \\
\hline
\end{tabular}




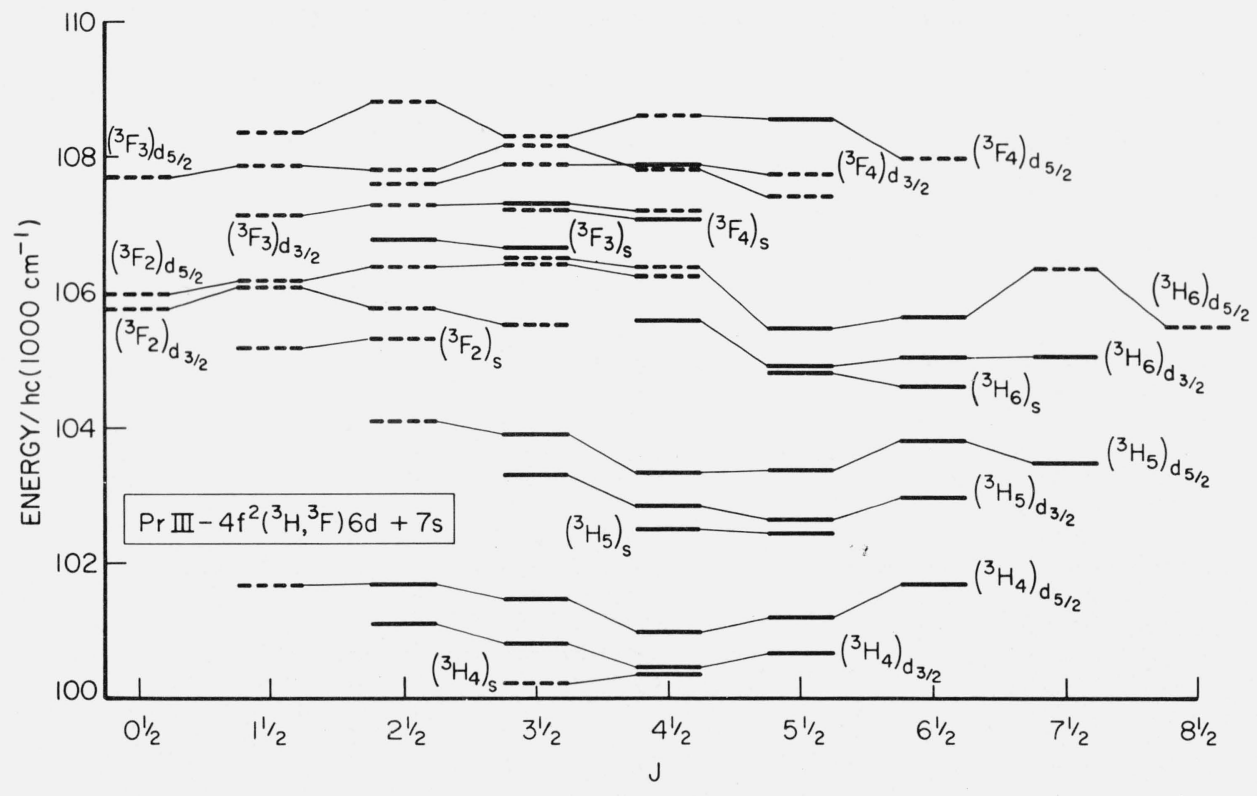

FigURE 3. Energy levels of the $4 \mathrm{f}^{2} 6 \mathrm{~d}$ and $4 \mathrm{f}^{2} 7 \mathrm{~s}$ configurations of Pr III designated in $J_{1 j}$-coupling. The $4 f^{2}$ core levels are given in parentheses followed by subscript $d$ or $s$ for the $6 d$ or $7 s$ configurations.

Levels not observed are represented by dashed lines at their calculated positions.

\subsection{The $4 f^{2} 8 s$ Configuration}

Only a few high-lying levels were found by adding the vacuum ultraviolet lines of PrIII to the $4 f^{2} 6 p$ group. These were characterized by the strict adherence of the observed lines to core level selection rules in $J_{1} j$-coupling. They were therefore either $4 f^{2} 7 d$ or $4 f^{2} 8 s$ levels. Their pair structure suggested the latter configuration and I attempted to fit them accord. ingly.

Here again, only levels based on the ${ }^{3} \mathrm{H}$ and ${ }^{3} \mathrm{~F}$ core levels were found. Therefore, the same fixed conditions on $4 f^{2}$ core parameters were used as for $4 f^{2} 6 d$ and $4 f^{2} 7 s$. The results of least squares fitting of the remaining parameters are given in table IX. The free core parameters $E^{3}$ and $\zeta_{4 f}$ are practically identical to those found for $4 f^{2} 6 d$ and $4 f^{2} 7 s$. Also, the parameter $G^{3}(f s)$ shows the same fractional increase from the Ce III value as does the same parameter of $4 f^{2} 7 s$ and $4 f^{2} 6 s$. These results strongly support the interpretation of these levels as $4 f^{2} 8 s$.

\section{The Ionization Energy}

The present extension of the analysis of Pr III provides a three member $4 f^{2} n s$ series $(n=6,7,8)$ which is suitable for a determination of the ionization energy of this ion.
TABLE IX. Fitted parameter values and associated standard errors for the $4 \mathrm{f}^{2} 7 \mathrm{~s}$ and $4 \mathrm{f}^{2} 8 \mathrm{~s}$ configurations of $\operatorname{Pr} \mathrm{III}$ in units of $\mathrm{cm}^{-1}$.

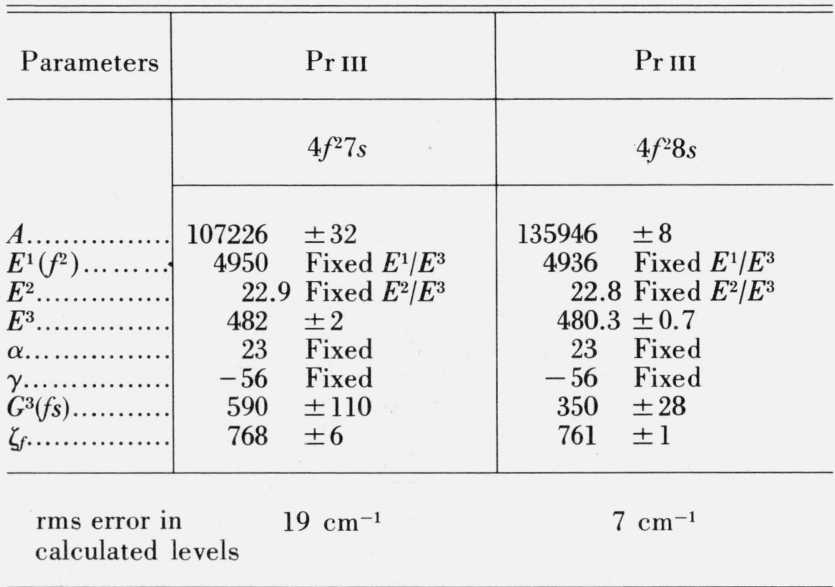

The levels based on the ${ }^{3} \mathrm{H}$ core term are available in the three configurations, and the purity of these levels is above 90 percent (in contrast to the ${ }^{3} \mathrm{~F}$ levels). Therefore, for the series terms I used the center of gravity of the levels built on the ${ }^{3} \mathrm{H}$ core. For the missing level in $4 f^{2}\left({ }^{3} \mathrm{H}\right) 7 s$ and $4 f^{2}\left({ }^{3} \mathrm{H}\right) 8 s$ the calculated position was substituted. The centers of gravity of 
$4 f^{2}\left({ }^{3} \mathrm{H}\right) 6 s, 7 s$, and $8 s$ and the fitted effective principal quantum numbers are:

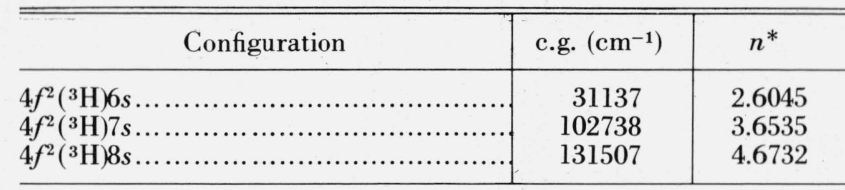

The Ritz formula to which these values are fitted is:

$$
T=-9 R /\left(n-3.2959-6.8432 \times 10^{-7} T\right)^{2} .
$$

To reduce the limit of this series to the lowest limit corresponding to the ionization energy, the center of gravity of the ${ }^{3} \mathrm{H}$ term of $4 f^{2}$ observed in $\operatorname{Pr}$ IV [18] was subtracted. This gives the value of $174284 \mathrm{~cm}^{-1}$ for the lowest series limit of Pr III.

The error resulting from the use of this three term series may be estimated from La III [24], where a four term $n s$ series $(n=6,7,8,9)$ is known. The ionization energy derived from this series agrees with those obtained with $n f$ and $n g$ series to within $10 \mathrm{~cm}^{-1}$. By using only the first three terms of the $n s$ series in La III one obtains a value for the ionization energy differing from that given by the four term series by $-115 \mathrm{~cm}^{-1}$. I therefore added an equivalent fractional amount to the calculated ionization energy of Pr III obtained from the three term series and estimate the uncertainty to be equal to this quantity. This gives the ionization energy of Pr III as $21.625 \mathrm{eV}\left(174420 \mathrm{~cm}^{-1}\right)$ with an estimated uncertainty of $0.016 \mathrm{eV}\left(130 \mathrm{~cm}^{-1}\right)$.

This procedure for estimating the correction for the quadratic term in the quantum defect is valid if series of this kind generally exhibit the same behavior. It was noted in reference 10 that an examination of the curves of the quantum defect $(\sigma)$ versus term energy $(T)$ for the $n s$ series of a large number of alkali-like atoms shows that their shapes are similar, and for the same period are practically identical (see table IV of ref. 10). Therefore, the use of the four-member series in La III to estimate the error in the ionization energy derived from a three-member series in PrIII is reasonable.

I am pleased to thank Prof. R. Chabbal, Director of Laboratoire Aimé Cotton, Orsay, France, for making available the excellent computer programs for calcu- lating energy matrices written by Y. Bordarier and A. Carlier of his staff. My first experience with these programs was gained at his laboratory where part of the present theoretical analysis was carried out.

I also thank Mrs. Z. Goldschmidt for providing NBS with the library of energy matrices compiled at Hebrew University, Jerusalem, Israel, by Prof. G. Racah and his co-workers.

The assistance of Dr. R. Cowan of the Los Alamos Scientific Laboratory in checking for errors in the energy matrices by independently calculating them was extremely valuable.

Dr. V. Kaufman generously contributed the exposures of the Pr spark made with the Eagle vacuum spectrograph.

\section{References}

[1] Sugar, J., Johns Hopkins Spectroscopic Rept. No. 22 (1961).

[2] Sugar, J., J. Opt. Soc. Am. 53, 831 (1963).

[3] Sugar, J., J. Opt. Soc. Am. 55, 33 (1965).

[4] Kaufman, V., and Andrew, K. L., J. Opt. Soc. Am. 52, 1223 (1962).

[5] Kaufman, V., Radziemski, L. J., Jr., and Andrew, K L., J. Opt. Soc. Am. 56, 911 (1966).

[6] Kaufman, V., and Ward, J. F., J. Opt. Soc. Am. 56, 1591 (1966).

[7] Kaufman, V., and Ward, J. F., Appl. Opt. 6, 43 (1967)-

[8] Edlén, B., Rep. Prog. Phys. 26, 181 (1963).

[9] The present work extended through two generations of computer programs for energy level searching. The first was written by G. Racah at NBS for the IBM 7090, and the second by J. Tech of NBS for the UNIVAC 1108

[10] Reader, J. and Sugar, J., Phys. Rev. 137, B784 (1965).

[11] Racah, G., Bull. Res. Counc. of Israel 8F, 1 (1959).

[12] Fano, U., Pratts, F., and Goldschmidt, Z., Phys. Rev. 129, 2643 (1963)

[13] Racah, G., Phys. Rev. 62, 438 (1942).

[14] Racah, G., Phys. Rev. 76, 1352 (1949).

[15] Goldschmidt, Z. B., Spectroscopic and Group Theoretical Methods in Physics, edited by F. Bloch et. al. (John Wiley \& Sons, Inc., New York, 1968).

[16] Spector N., J. Opt. Soc. Am. 55, 492 (1965).

[17] Trees, R. E., J. Opt. Soc. Am. 54, 651 (1964).

[18] Sugar J., J. Opt. Soc. Am. 55, 1058 (1965).

[19] Spector N., J. Opt. Soc. Am. 54, 1359 (1964).

[20] Sack, N., Phys. Rev. 102, 1302 (1956).

[21] The parameters of $4 f^{2}$ for Pr IV given in table III differ from those in ref. 18 where $\gamma$ was ignored.

[22] Judd, B. R., J. Opt. Soc. Am. 58, 1311 (1968).

[23] Feneuille, S., and Pelletier-Allard N., Physica 40, 347 (1969) The parameter $\gamma$ was added in $4 f^{2} 6 s$. The calculation of $4 f^{2} 5 d$ was greatly improved by the addition of two-body effective parameters for nonequivalent electrons.

[24] Sugar J., and Kaufman, V., J. Opt. Soc. Am. 55, 1283 (1965). 
TABLE X. Observed spectral lines of Pr III in the vacuum ultra violet region

\begin{tabular}{|c|c|c|c|c|c|c|c|}
\hline $\begin{array}{c}\lambda_{\text {vac }} \\
\AA\end{array}$ & Intensity & $\begin{array}{c}\sigma \\
\left(\mathrm{cm}^{-1}\right)\end{array}$ & Classification $^{\text {a }}$ & $\begin{array}{c}\lambda_{\mathrm{vac}} \\
\AA\end{array}$ & Intensity & $\begin{array}{c}\sigma \\
\left(\mathrm{cm}^{-1}\right)\end{array}$ & Classification $^{\text {a }}$ \\
\hline 2103.455 & 3 & 47540.8 & $23844_{9 / 2}-71385_{h / 2}$ & 2085.148 & 2 & 47958.2 & \\
\hline 2102.907 & 20 & 47553.2 & & 2084.954 & 10 & 47962.7 & \\
\hline 2102.492 & 3 & 47562.6 & & 2084.699 & 3 & 47968.5 & $23532_{5 / 2}-71501_{3 / 2}^{\circ}$ \\
\hline 2101.877 & 10 & 47576.5 & & & & & $25409_{7 / 2}-73378_{7 / 2}^{\circ}$ \\
\hline 2101.778 & 100 & 47578.8 & $23442_{11 / 2}-71021_{9 / 2}^{\circ}$ & 2084.344 & 60 & 47976.7 & $14558_{9 / 2}-62535_{9 / 2}^{\circ}$ \\
\hline 2101.651 & 2 & 47581.6 & & 2083.504 & 1 & 47996.1 & $25033_{9 / 2}-73029_{9 / 2}^{\circ}$ \\
\hline 2099.948 & 5 & 47620.2 & $25409_{7 / 2}-73029_{9 / 2}^{\circ}$ & 2083.412 & 1 & 47998.2 & $19872_{7 / 2}-67870_{9 / 2}^{\circ}$ \\
\hline 2099.757 & 50 & 47624.6 & & 2083.123 & 400 & 48004.8 & $13352_{11 / 2}-61357_{9 / 2}^{\circ}$ \\
\hline 2099.757 & 50 & 47624.6 & $29267_{5 / 2}-76892_{3 / 2}^{\circ}$ & 2082.879 & 2 & 48010.5 & \\
\hline 2099.402 & 200 & 47632.6 & $16135_{7 / 2}-63768_{7 / 2}^{\circ}$ & 2082.810 & 3 & 48012.1 & $21418_{5 / 2}-69431_{7 / 2}^{\circ}$ \\
\hline 2098.974 & 3 & 47642.3 & & 2082.653 & 3 & 48015.7 & \\
\hline 2098.903 & 20 & 47643.9 & $20848_{5 / 2}-68492^{\circ}{ }_{7 / 2}$ & 2081.788 & 2 & 48035.6 & $27604_{9 / 2}-75640_{11 / 2}^{\circ}$ \\
\hline 2098.523 & 100 & 47652.6 & $21755_{11 / 2}-69408^{\circ}{ }_{11 / 2}$ & 2080.866 & 1 & 48056.9 & \\
\hline 2098.275 & 5 & 47658.2 & $26446_{7 / 2}-74105_{5 / 2}^{\circ}$ & 2080.280 & 30 & 48070.4 & $21611_{5 / 2}-69681_{5 / 2}^{\circ}$ \\
\hline 2097.806 & 100 & 47668.8 & $17627_{9 / 2}-65295^{\circ} 7 / 2$ & 2079.497 & 100 & 48088.6 & $23647_{13 / 2}-71736_{11 / 2}^{\circ / 2}$ \\
\hline 2097.601 & 1000 & 47673.5 & $12846_{9 / 2}-60520^{\circ}{ }_{7 / 2}$ & 2079.441 & 300 & 48089.8 & $19308_{11 / 2}-67398_{9 / 2}^{\circ}$ \\
\hline 2097.513 & 500 & 47675.5 & $14859_{11 / 2}-62535_{9 / 2}^{\circ}$ & 2079.020 & 1 & 48099.6 & $16135_{7 / 2}-64235_{9 / 2}^{\circ / 2}$ \\
\hline 2097.284 & 20 & 47680.7 & $18241_{11 / 2}-65922^{\circ}{ }_{11 / 2}$ & 2078.645 & 20 & 48108.3 & $27452_{5 / 2}-75560_{5 / 2}^{\circ}$ \\
\hline 2097.234 & 100 & 47681.8 & $14558_{9 / 2}-62240^{\circ}{ }_{11 / 2}$ & 2078.489 & 20 & 48111.9 & $31254_{7 / 2}-79366_{5 / 2}^{\circ}$ \\
\hline 2097.160 & 40 & 47683.5 & $21294_{7 / 2}-68978_{5 / 2}^{\circ}$ & 2078.426 & 3 & 48113.3 & \\
\hline 2097.075 & 5 & 47685.5 & $24309_{3 / 2}-71994_{5 / 2}^{\circ}$ & 2077.544 & 60 & 48133.8 & $23844_{9 / 2}-71978_{7 / 2}^{\circ}$ \\
\hline 2096.985 & 5 & 47687.5 & & 2077.450 & 40 & 48135.9 & $21294_{7 / 2}-69431_{7 / 2}^{\circ}$ \\
\hline 2096.890 & 5 & 47689.7 & $27604_{9 / 2}-75294_{7 / 2}^{\circ}$ & 2077.337 & 3 & 48138.6 & $20848_{5 / 2}-68987_{7 / 2}^{\circ}$ \\
\hline 2096.832 & 200 & 47691.0 & $18990_{7 / 2}-66681_{5 / 2}^{\circ}$ & 2076.841 & 200 & 48150.0 & $23442_{11 / 2}-71592_{9 / 2}^{\circ}$ \\
\hline 2096.787 & 6 & 47692.0 & $21294_{7 / 2}-68987^{\circ} 7 / 2$ & 2076.505 & 3 & 48157.8 & $27604_{9 / 2}-75762_{9 / 2}^{\circ}$ \\
\hline 2096.496 & 400 & 47698.6 & $14859_{11 / 2}-62558^{\circ}{ }_{11 / 2}$ & 2076.358 & 100 & 48161.2 & $45805_{9 / 2}-93967^{\circ}{ }_{7 / 2}$ \\
\hline 2094.953 & 20 & 47733.8 & $23651_{7 / 2}-71385^{\circ}{ }_{7 / 2}^{\circ}$ & 2075.991 & 300 & 48169.8 & $19700_{11 / 2}-67870_{9 / 2}^{\circ}$ \\
\hline 2094.676 & 400 & 47740.1 & $19308_{11 / 2}-67049_{9 / 2}^{\circ}$ & 2075.747 & 500 & 48175.4 & $15045_{5 / 2}-63221_{3 / 2}^{\circ}$ \\
\hline 2094.155 & 4000 & 47752.0 & $17113_{13 / 2}-64865^{\circ}{ }_{11 / 2}$ & 2074.851 & 5 & 48196.2 & \\
\hline 2093.909 & 5 & 47757.6 & & 2073.739 & 20 & 48222.1 & $21755_{11 / 2}-69978^{\circ}{ }_{11 / 2}$ \\
\hline 2093.424 & 40 & 47768.6 & & 2073.462 & 200 & 48228.5 & $20315_{9 / 2}-68544_{9 / 2}^{\circ}$ \\
\hline 2092.509 & 10 & 47789.5 & & 2073.215 & 3 & 48234.3 & \\
\hline 2091.826 & 30 & 47805.1 & $20160_{3 / 2}-67965_{3 / 2}^{\circ}$ & 2072.886 & 10 & 48241.9 & $24788_{9 / 2}-73029_{9 / 2}^{\circ}$ \\
\hline 2091.758 & 20 & 47806.7 & $19872_{7 / 2}-67679^{\circ}{ }_{7 / 2}$ & 2072.580 & 15 & 48249.0 & \\
\hline 2091.411 & 4000 & 47814.6 & $18921_{15 / 2}-66735_{13 / 2}^{\circ}$ & 2072.534 & 400 & 48250.1 & $18990_{7 / 2}-67240_{7 / 2}^{\circ}$ \\
\hline 2091.238 & 100 & 47818.6 & $14859_{11 / 2}-62678_{13 / 2}^{\circ}$ & 2071.991 & 80 & 48262.8 & $21418_{5 / 2}-69681_{5 / 2}^{\circ}$ \\
\hline 2090.153 & 20 & 47843.4 & $21294_{7 / 2}-69138_{9 / 2}^{\circ}$ & 2071.533 & 5 & 48273.4 & $22747_{9 / 2}-71021_{9 / 2}^{\circ / 2}$ \\
\hline 2089.744 & 1 & 47852.7 & $23532_{5 / 2}-71385^{\circ}{ }_{7 / 2}$ & 2070.768 & 50 & 48291.3 & $15525_{11 / 2}-63816_{11 / 2}^{\circ}$ \\
\hline 2089.473 & 10 & 47859.0 & $18063_{9 / 2}-65922^{\circ}{ }_{11 / 2}$ & 2070.649 & 200 & 48294.0 & $23442_{11 / 2}-71736_{11 / 2}^{\circ}$ \\
\hline 2089.306 & 5 & 47862.8 & $18990_{\tau / 2}-66852^{\circ}{ }_{7 / 2}$ & 2070.338 & 50 & 48301.3 & $16516_{7 / 2}-64817_{5 / 2}^{\circ}$ \\
\hline 2088.848 & 2 & 47873.3 & $21535_{9 / 2}-69408_{11 / 2}^{\circ}$ & 2070.042 & 400 & 48308.2 & $17627_{9 / 2}-65935_{7 / 2}^{\circ}$ \\
\hline 2088.769 & 10 & 47875.1 & $32288_{3 / 2}-80164_{3 / 2}^{\circ}$ & 2069.258 & 50 & 48326.5 & $23651_{7 / 2}-71978_{7 / 2}^{\circ}$ \\
\hline 2088.632 & 10 & 47878.2 & & 2068.559 & 30 & 48342.8 & $23651_{7 / 2}-71994_{5 / 2}^{\circ}$ \\
\hline 2088.346 & 400 & 47884.8 & $16516_{7 / 2}-64401_{5 / 2}^{\circ}$ & 2068.261 & 200 & 48349.8 & $39870_{9 / 2}-88220_{9 / 2}^{\circ}$ \\
\hline 2088.042 & 5 & 47891.8 & $23844_{9 / 2}-71736_{11 / 2}^{\circ}$ & 2067.712 & 200 & 48362.6 & $15454_{13 / 2}-63816_{11 / 2}^{\circ}$ \\
\hline 2087.387 & 4 & 47906.8 & $18241_{11 / 2}-66148_{13 / 2}^{\circ}$ & 2067.034 & 200 & 48378.5 & \\
\hline 2087.300 & 4 & 47908.8 & & 2066.270 & 10 & 48396.4 & \\
\hline 2087.200 & 4 & 47911.1 & & 2065.895 & 300 & 48405.2 & $18990_{7 / 2}-67395_{5 / 2}^{\circ}$ \\
\hline 2086.712 & 10 & 47922.3 & $20315_{9 / 2}-68238_{11 / 2}^{\circ}$ & 2065.177 & 5 & 48422.0 & $27138_{7 / 2}-75560_{5 / 2}^{\circ}$ \\
\hline 2085.246 & 30 & 47956.0 & $28936_{3 / 2}-76892_{3 / 2}^{\circ}$ & 2064.736 & 1000 & 48432.3 & $17534_{15 / 2}-65967^{\circ}{ }_{13 / 2}$ \\
\hline
\end{tabular}

${ }^{\text {a }}$ For doubly-classified lines, the wavelength is entered only once. 
TABLE X. Observed spectral lines of Pr III in the vacuum ultra violet region-Continued

\begin{tabular}{|c|c|c|c|c|c|c|c|}
\hline $\begin{array}{c}\lambda_{\mathrm{vac}} \\
\AA\end{array}$ & Intensity & $\begin{array}{c}\sigma \\
\left(\mathrm{cm}^{-1}\right)\end{array}$ & Classification $^{a}$ & $\begin{array}{c}\lambda_{\text {vac }} \\
\AA\end{array}$ & Intensity & $\begin{array}{c}\sigma \\
\left(\mathrm{cm}^{-1}\right)\end{array}$ & Classification $^{\mathrm{a}}$ \\
\hline $\begin{array}{l}2064.291 \\
2064.176 \\
2063.966 \\
2063.765 \\
2063.592\end{array}$ & $\begin{array}{r}2 \\
10 \\
5 \\
2 \\
1\end{array}$ & $\begin{array}{l}48442.8 \\
48445.5 \\
48450.4 \\
48455.1 \\
48459.2\end{array}$ & $\begin{array}{l}21535_{9 / 2}-69978_{11 / 2}^{\circ} \\
23532_{5 / 2}-71978^{\circ}{ }_{7 / 2} \\
23050_{3 / 2}-71501^{\circ}{ }_{3 / 2} \\
19872_{7 / 2}-68331^{\circ}{ }_{7 / 2}\end{array}$ & $\begin{array}{l}2048.425 \\
2048.148 \\
2047.788 \\
2047.369 \\
2047.331\end{array}$ & $\begin{array}{r}10 \\
100 \\
20 \\
80 \\
1\end{array}$ & $\begin{array}{l}48818.0 \\
48824.6 \\
48833.2 \\
48843.2 \\
48844.1\end{array}$ & $\begin{array}{l}20160_{3 / 2}-68978_{5 / 2}^{\circ} \\
19700_{11 / 2}-68525^{\circ}{ }_{11 / 2} \\
20848_{5 / 2}-69681_{5 / 2}^{\circ} \\
19700_{11 / 2}-68544_{9 / 2}^{\circ}\end{array}$ \\
\hline $\begin{array}{l}2063.478 \\
2063.161 \\
2062.870 \\
2062.457\end{array}$ & $\begin{array}{r}3 \\
4 \\
200 \\
200\end{array}$ & $\begin{array}{l}48461.9 \\
48469.3 \\
48476.2 \\
48485.9\end{array}$ & $\begin{array}{l}23532_{5 / 2}-71994_{5 / 2}^{\circ} \\
18211_{5 / 2}-66681_{5 / 2}^{\circ} \\
27138_{7 / 2}-75614_{5 / 2}^{\circ} \\
20315_{9 / 2}^{\circ}-68801_{7 / 2}^{\circ} \\
23050_{3 / 2}-71536_{5 / 2}^{\circ}\end{array}$ & $\begin{array}{l}2047.208 \\
2046.923 \\
2046.754 \\
2046.692 \\
2046.390\end{array}$ & $\begin{array}{r}2 \\
70 \\
10 \\
20 \\
10\end{array}$ & $\begin{array}{l}48847.0 \\
48853.8 \\
48857.8 \\
48859.3 \\
48866.5\end{array}$ & $\begin{array}{l}26446_{7 / 2}-75294^{\circ}{ }_{7 / 2} \\
17113_{13 / 2}-65967^{\circ}{ }_{13 / 2} \\
22527_{7 / 2}-71385^{\circ}{ }_{7 / 2} \\
29835_{9 / 2}-78694^{\circ}{ }_{11 / 2}\end{array}$ \\
\hline $\begin{array}{l}2061.421 \\
2060.746 \\
2060.636 \\
2060.569 \\
2060.054\end{array}$ & $\begin{array}{r}80 \\
20 \\
10 \\
30 \\
1\end{array}$ & $\begin{array}{l}48510.2 \\
48526.1 \\
48528.7 \\
48530.3 \\
48542.4\end{array}$ & $\begin{array}{l}12846_{9 / 2}-61357_{9 / 2}^{\circ} \\
25934_{5 / 2}-74463_{3 / 2}^{\circ} \\
15045_{5 / 2}-63576_{5 / 2}^{\circ}\end{array}$ & $\begin{array}{l}2045.914 \\
2045.564 \\
2045.465 \\
2044.686 \\
2044.070\end{array}$ & $\begin{array}{r}10 \\
2 \\
200 \\
10 \\
1\end{array}$ & $\begin{array}{l}48877.9 \\
48886.3 \\
48888.6 \\
48907.3 \\
48922.0\end{array}$ & $\begin{array}{l}19360_{13 / 2}-68238^{\circ}{ }_{11 / 2} \\
13352_{11 / 2}-62240^{\circ}{ }_{11 / 2}^{\circ} \\
24470_{7 / 2}-73378^{\circ}{ }_{7 / 2}\end{array}$ \\
\hline $\begin{array}{l}2059.891 \\
2059.245 \\
2058.796 \\
2058.663 \\
2058.371\end{array}$ & $\begin{array}{r}10 \\
4000 \\
60 \\
30 \\
10\end{array}$ & $\begin{array}{l}48546.2 \\
48561.5 \\
48572.1 \\
48575.2 \\
48582.1\end{array}$ & $\begin{array}{l}19308_{11 / 2}-67870_{9 / 2}^{\circ} \\
25033_{9 / 2}-73609^{\circ}{ }_{11 / 2} \\
35828_{9 / 2}-84410_{9 / 2}^{\circ}\end{array}$ & $\begin{array}{l}2043.773 \\
2043.103 \\
2042.616 \\
2041.925 \\
2039.381\end{array}$ & $\begin{array}{r}500 \\
50 \\
400 \\
2 \\
200\end{array}$ & $\begin{array}{l}48929.1 \\
48945.2 \\
48956.8 \\
48973.4 \\
49034.5\end{array}$ & $\begin{array}{l}19872_{7 / 2}-68801^{\circ}{ }_{7 / 2} \\
19360_{13 / 2}-68305_{15 / 2}^{\circ} \\
14859_{11 / 2}-63816^{\circ}{ }_{11 / 2} \\
14558_{9 / 2}-63593_{9 / 2}^{\circ}\end{array}$ \\
\hline $\begin{array}{l}2058.090 \\
2057.554 \\
2057.042 \\
2056.771 \\
2056.545\end{array}$ & $\begin{array}{r}5 \\
100 \\
10 \\
5 \\
30\end{array}$ & $\begin{array}{l}48588.7 \\
48601.4 \\
48613.5 \\
48619.9 \\
48625.2\end{array}$ & $\begin{array}{l}35828_{9 / 2}-84430^{\circ}{ }_{7 / 2} \\
17534_{15 / 2}-66148^{\circ}{ }_{13 / 2} \\
19872_{7 / 2}-68492^{\circ}{ }_{7 / 2} \\
15525_{11 / 2}-64150^{\circ}{ }_{11 / 2}\end{array}$ & $\begin{array}{l}2038.682 \\
2038.366 \\
2037.578 \\
2036.415 \\
2036.103\end{array}$ & $\begin{array}{c}1 \\
1 \\
3 \\
20 c l \\
1\end{array}$ & $\begin{array}{l}49051.3 \\
49058.9 \\
49077.9 \\
49105.9 \\
49113.4\end{array}$ & $19872_{7 / 2}-68978_{5 / 2}^{\circ}$ \\
\hline $\begin{array}{l}2056.409 \\
2056.326 \\
2054.597 \\
2054.509 \\
2054.168\end{array}$ & $\begin{array}{r}30 \\
100 \\
50 \\
1000 \\
200\end{array}$ & $\begin{array}{l}48628.4 \\
48630.4 \\
48671.4 \\
48673.4 \\
48681.5\end{array}$ & $\begin{array}{l}29835_{9 / 2}-78463_{7 / 2}^{\circ} \\
30505_{11 / 2}-79136_{13 / 2}^{\circ} \\
20315_{9 / 2}-68987^{\circ}{ }_{7 / 2}^{\circ} \\
14558_{9 / 2}-63232_{7 / 2}^{\circ} \\
16135_{7 / 2}-64817_{5 / 2}^{\circ}\end{array}$ & $\begin{array}{l}2036.061 \\
2035.210 \\
2034.894 \\
2034.290 \\
2034.186\end{array}$ & $\begin{array}{r}100 \\
10 \\
100 \\
1 \\
7\end{array}$ & $\begin{array}{l}49114.4 \\
49135.0 \\
49142.6 \\
49157.2 \\
49159.7\end{array}$ & $\begin{array}{l}19872_{7 / 2}-68987^{\circ}{ }_{7 / 2} \\
21238_{13 / 2}-70381_{13 / 2}^{\circ} \\
18241_{11 / 2}-67398_{9 / 2}^{\circ} \\
16135_{7 / 2}-65295^{\circ}{ }_{7 / 2}\end{array}$ \\
\hline $\begin{array}{l}2053.815 \\
2053.531 \\
2052.953 \\
2052.434\end{array}$ & $\begin{array}{r}10 \\
1000 \\
2000\end{array}$ & $\begin{array}{l}48689.9 \\
48696.6 \\
48710.3 \\
48722.6\end{array}$ & $\begin{array}{l}15525_{11 / 2}-64215^{\circ}{ }_{13 / 2} \\
15454_{13 / 2}-64150^{\circ}{ }_{11 / 2} \\
13352_{11 / 2}-62062_{9 / 2}^{\circ} \\
15525_{11 / 2}-64235_{9 / 2}^{\circ} \\
15045_{5 / 2}^{\circ}-63768^{\circ}{ }_{7 / 2}^{\circ}\end{array}$ & $\begin{array}{l}2033.950 \\
2033.719 \\
2033.478 \\
2033.207\end{array}$ & $\begin{array}{r}2000 \\
10 \\
40 \\
200\end{array}$ & $\begin{array}{l}49165.4 \\
49171.0 \\
49176.8 \\
49183.4\end{array}$ & $\begin{array}{l}19360_{13 / 2}-68525^{\circ}{ }_{11 / 2} \\
18063_{9 / 2}-67240^{\circ}{ }_{7 / 2} \\
13352_{11 / 2}-62535_{9 / 2}^{\circ} \\
18211_{5 / 2}-67395_{5 / 2}^{\circ}\end{array}$ \\
\hline $\begin{array}{l}2052.198 \\
2052.131 \\
2052.078 \\
2052.045 \\
2051.988\end{array}$ & $\begin{array}{r}3 \\
3 \\
10 \\
1 \\
100\end{array}$ & $\begin{array}{l}48728.2 \\
48729.8 \\
48731.1 \\
48731.9 \\
48733.2\end{array}$ & $\begin{array}{l}18211_{5 / 2}-66943_{5 / 2}^{\circ} \\
14859_{11 / 2}-63593_{9 / 2}^{\circ}\end{array}$ & $\begin{array}{l}2033.129 \\
2033.015 \\
2032.480 \\
2032.253 \\
2032.117\end{array}$ & $\begin{array}{r}50 \\
100 \\
200 \\
400 \\
1000\end{array}$ & $\begin{array}{l}49185.3 \\
49188.0 \\
49201.0 \\
49206.5 \\
49209.8\end{array}$ & $\begin{array}{l}23844_{9 / 2}-73029_{9 / 2}^{\circ} \\
17113_{13 / 2}-66301^{\circ}{ }_{15 / 2} \\
17534_{15 / 2}-66735^{\circ}{ }_{13 / 2} \\
13352_{11 / 2}-62558^{\circ}{ }_{11 / 2} \\
14558_{9 / 2}-63768^{\circ}{ }_{7 / 2}\end{array}$ \\
\hline $\begin{array}{l}2051.736 \\
2050.969 \\
2050.911 \\
2050.812 \\
2050.587\end{array}$ & $\begin{array}{r}200 \\
20 \\
10 \\
400 \\
200\end{array}$ & $\begin{array}{l}48739.2 \\
48757.4 \\
48758.8 \\
48761.2 \\
48766.5\end{array}$ & $\begin{array}{l}21238_{13 / 2}-69978_{11 / 2}^{\circ} \\
12846_{9 / 2}-61605^{\circ}{ }_{7 / 2} \\
15454_{13 / 2}-64215_{13 / 2}^{\circ} \\
17534_{15 / 2}-66301_{15 / 2}^{\circ}\end{array}$ & $\begin{array}{l}2031.865 \\
2031.558 \\
2031.455 \\
2031.256 \\
2030.131\end{array}$ & $\begin{array}{r}400 \\
1 \\
400 \\
10 \\
100\end{array}$ & $\begin{array}{l}49215.9 \\
49223.3 \\
49225.8 \\
49230.6 \\
49257.9\end{array}$ & $\begin{array}{l}12846_{9 / 2}-62062_{9 / 2}^{\circ} \\
22277_{3 / 2}-71501_{3 / 2}^{\circ} \\
17627_{9 / 2}^{\circ}-66852^{\circ}{ }_{7 / 2} \\
22747_{9 / 2}-71978_{7 / 2}^{\circ} \\
14558_{9 / 2}-63816_{11 / 2}^{\circ}\end{array}$ \\
\hline $\begin{array}{l}2050.036 \\
2049.624 \\
2048.865 \\
2048.798 \\
2048.630\end{array}$ & $\begin{array}{r}20 \\
20 \\
400 \\
100 \\
1\end{array}$ & $\begin{array}{l}48779.6 \\
48789.4 \\
48807.5 \\
48809.1 \\
48813.1\end{array}$ & $\begin{array}{l}16516_{7 / 2}-65295_{7 / 2}^{\circ} \\
18063_{9 / 2}-66852^{\circ}{ }_{7 / 2} \\
18241_{11 / 2}-67049_{9 / 2}^{\circ} \\
17113_{13 / 2}-65922^{\circ}{ }_{11 / 2}\end{array}$ & $\begin{array}{l}2029.983 \\
2029.814 \\
2029.694 \\
2029.540 \\
2029.192\end{array}$ & $\begin{array}{r}2 \\
7 \\
2 \\
20 \\
300\end{array}$ & $\begin{array}{l}49261.5 \\
49265.6 \\
49268.5 \\
49272.2 \\
49280.7\end{array}$ & $\begin{array}{l}19872_{7 / 2}-69138_{9 / 2}^{\circ} \\
35137_{3 / 2}-84409^{\circ}{ }_{3 / 2}\end{array}$ \\
\hline
\end{tabular}

${ }^{a}$ For doubly-classified lines, the wavelength is entered only once. 
TABLE X. Observed spectral lines of Pr III in the vacuum ultra violet region-Continued

\begin{tabular}{|c|c|c|c|c|c|c|c|}
\hline$\lambda_{\text {vac }}$ & Intensity & $\begin{array}{c}\sigma \\
\left(\mathrm{cm}^{-1}\right)\end{array}$ & Classification $^{\text {a }}$ & $\lambda_{\text {yac }}$ & Intensity & $\begin{array}{c}\sigma \\
\left(\mathrm{cm}^{-1}\right)\end{array}$ & Classification $^{\mathrm{a}}$ \\
\hline $\begin{array}{l}2028.959 \\
2028.926 \\
2028.780 \\
2028.209 \\
2027.315\end{array}$ & $\begin{array}{r}2 \\
5 \\
100 \\
40 \\
3\end{array}$ & $\begin{array}{l}49286.4 \\
49287.2 \\
49290.7 \\
49304.6 \\
49326.3\end{array}$ & $\begin{array}{l}44679_{7 / 2}-93967^{\circ}{ }_{7 / 2} \\
14859_{11 / 2}-64150^{\circ}{ }_{11 / 2} \\
22080_{7 / 2}-71385^{\circ}{ }_{7 / 2} \\
13352_{11 / 2}-62678^{\circ}{ }_{13 / 2}\end{array}$ & $\begin{array}{l}2009.107 \\
2008.066 \\
2007.738 \\
2006.763\end{array}$ & $\begin{array}{r}40 \\
10 \\
20 \\
1\end{array}$ & $\begin{array}{l}49773.4 \\
49799.2 \\
49807.3 \\
49831.5\end{array}$ & $\begin{array}{l}17627_{9 / 2}-67398_{9 / 2}^{\circ} \\
16135_{7 / 2}-65909^{\circ}{ }_{5 / 2} \\
16135_{7 / 2}-65935_{7 / 2}^{\circ} \\
18063_{9 / 2}-67870_{9 / 2}^{\circ}\end{array}$ \\
\hline $\begin{array}{l}2027.194 \\
2027.102 \\
2026.948 \\
2026.694 \\
2026.007\end{array}$ & $\begin{array}{r}40 \\
300 \\
10 \\
10 \\
30<l\end{array}$ & $\begin{array}{l}49329.3 \\
49331.5 \\
49335.3 \\
49341.4 \\
49358.2\end{array}$ & $\begin{array}{l}15525_{11 / 2}-64857_{9 / 2}^{\circ} \\
18063_{9 / 2}-67398_{9 / 2}^{\circ} \\
18990_{7 / 2}-68331_{7 / 2}^{\circ}\end{array}$ & $\begin{array}{l}2006.565 \\
2006.072 \\
2005.817 \\
2004.416 \\
2003.908\end{array}$ & $\begin{array}{l}30 \\
10 \\
30 \\
10 \\
20\end{array}$ & $\begin{array}{l}49836.4 \\
49848.7 \\
49855.0 \\
49889.8 \\
49902.5\end{array}$ & $\begin{array}{l}21755_{11 / 2}-71592_{9 / 2}^{\circ} \\
30505_{11 / 2}-80360^{\circ}{ }_{11 / 2} \\
21611_{5 / 2}-71501_{3 / 2}^{\circ}\end{array}$ \\
\hline $\begin{array}{l}2025.296 \\
2024.954 \\
2024.812 \\
2024.573 \\
2024.540\end{array}$ & $\begin{array}{c}30 \\
100 \\
2 \\
20 c l \\
400\end{array}$ & $\begin{array}{l}49375.5 \\
49383.8 \\
49387.3 \\
49393.1 \\
49393.9\end{array}$ & $\begin{array}{l}14859_{11 / 2}-64235_{9 / 2}^{\circ} \\
18921_{15 / 2}-68305_{15 / 2}^{\circ} \\
16516_{7 / 2}-65909_{5 / 2}^{\circ} \\
12846_{9 / 2}-62240_{11 / 2}^{\circ}\end{array}$ & $\begin{array}{l}2003.001 \\
2002.296 \\
2001.839 \\
2001.548 \\
2001.441\end{array}$ & $\begin{array}{r}10 \\
2 \\
1 \\
10 \\
40\end{array}$ & $\begin{array}{l}49925.1 \\
49942.7 \\
49954.1 \\
49961.3 \\
49964.0\end{array}$ & $23647_{13 / 2}-73609^{\circ}{ }_{11 / 2}$ \\
\hline $\begin{array}{l}2024.298 \\
2023.848 \\
2023.390 \\
2023.005 \\
2022.766\end{array}$ & $\begin{array}{r}70 \\
10 \\
10 \\
200 \\
70\end{array}$ & $\begin{array}{l}49399.8 \\
49410.8 \\
49422.0 \\
49431.4 \\
49437.3\end{array}$ & $\begin{array}{l}15454_{13 / 2}-64865_{11 / 2}^{\circ} \\
17627_{9 / 2}-67049_{9 / 2}^{\circ} \\
29263_{13 / 2}-78694_{11 / 2}^{\circ} \\
19700_{11 / 2}^{\circ}-69138_{9 / 2}^{\circ}\end{array}$ & $\begin{array}{l}2001.049 \\
2000.784 \\
2000.587 \\
2000.462 \\
2000.116\end{array}$ & $\begin{array}{r}5 \\
2 \\
200 \\
20 \\
400\end{array}$ & $\begin{array}{l}49973.8 \\
49980.4 \\
49985.3 \\
49988.4 \\
49997.1\end{array}$ & $\begin{array}{l}28720_{9 / 2}-78694_{11 / 2}^{\circ} \\
21755_{11 / 2}-71736_{11 / 2}^{\circ} \\
19700_{11 / 2}-69686_{9 / 2}^{\circ} \\
18990_{7 / 2}-68978_{5 / 2}^{\circ} \\
14859_{11 / 2}^{\circ}-64857_{9 / 2}^{\circ}\end{array}$ \\
\hline $\begin{array}{l}2022.370 \\
2022.027 \\
2021.544 \\
2021.249 \\
2020.778\end{array}$ & $\begin{array}{r}3 \\
1 \\
50 \\
1 \\
10\end{array}$ & $\begin{array}{l}49446.9 \\
49455.3 \\
49467.1 \\
49474.4 \\
49485.9\end{array}$ & $\begin{array}{l}22080_{7 / 2}-71536_{5 / 2}^{\circ} \\
22527_{7 / 2}-71994_{5 / 2}^{\circ} \\
21535_{9 / 2}-71021_{9 / 2}^{\circ}\end{array}$ & $\begin{array}{l}1999.902 \\
1999.795 \\
1998.905 \\
1998.598\end{array}$ & $\begin{array}{r}30 \\
100 \\
30 \\
10\end{array}$ & $\begin{array}{l}50002.4 \\
50005.1 \\
50027.4 \\
50035.1\end{array}$ & $\begin{array}{l}18990_{7 / 2}-68987^{\circ}{ }_{7 / 2} \\
24461_{5 / 2}-74463_{3 / 2}^{\circ} \\
14859_{11 / 2}-64865^{\circ}{ }_{11 / 2}\end{array}$ \\
\hline $\begin{array}{l}2018.512 \\
2018.385 \\
2017.745 \\
2016.711 \\
2016.637\end{array}$ & $\begin{array}{r}1 \\
10 \\
30 \\
100 \\
2\end{array}$ & $\begin{array}{l}49541.4 \\
49544.6 \\
49560.3 \\
49585.7 \\
49587.5\end{array}$ & $\begin{array}{l}26095_{11 / 2}-75640_{11 / 2}^{\circ} \\
29835_{9 / 2}-79395^{\circ}{ }_{7 / 2} \\
23442_{11 / 2}-73029_{9 / 2}^{\circ}\end{array}$ & $\begin{array}{l}1998.301 \\
1998.064 \\
1997.912 \\
1996.715 \\
1996.423\end{array}$ & $\begin{array}{r}1 \\
400 \\
20 \\
30 \\
3\end{array}$ & $\begin{array}{l}50042.5 \\
50048.4 \\
50052.2 \\
50082.3 \\
50089.6\end{array}$ & $\begin{array}{l}19360_{13 / 2}-69408_{11 / 2}^{\circ} \\
17627_{9 / 2}-67679^{\circ}{ }_{7 / 2} \\
21418_{5 / 2}-71501_{3 / 2}^{\circ}\end{array}$ \\
\hline $\begin{array}{l}2016.463 \\
2015.591 \\
2015.488 \\
2015.267 \\
2015.214\end{array}$ & $\begin{array}{r}1 \\
100 \\
200 \\
20 \\
100\end{array}$ & $\begin{array}{l}49591.8 \\
49613.2 \\
49615.8 \\
49621.2 \\
49622.5\end{array}$ & $\begin{array}{l}14558_{9 / 2}-64150_{11 / 2}^{\circ} \\
17627_{9 / 2}-67240^{\circ}{ }_{7 / 2} \\
18063_{9 / 2}-67679^{\circ}{ }_{7 / 2} \\
29267_{5 / 2}-78889^{\circ}{ }_{3 / 2}^{\circ} \\
17113_{13 / 2}-66735_{13 / 2}^{\circ}\end{array}$ & $\begin{array}{l}1996.023 \\
1995.989 \\
1995.216 \\
1994.856 \\
1994.692\end{array}$ & $\begin{array}{c}5 c l \\
10 \\
100 \\
1 \\
400\end{array}$ & $\begin{array}{l}50099.6 \\
50100.5 \\
50119.9 \\
50128.9 \\
50133.0\end{array}$ & $\begin{array}{l}19308_{11 / 2}-69408_{11 / 2}^{\circ} \\
18211_{5 / 2}-68331_{7 / 2}^{\circ} \\
18241_{11 / 2}-68374_{9 / 2}^{\circ}\end{array}$ \\
\hline $\begin{array}{l}2014.946 \\
2014.405 \\
2013.897 \\
2013.015 \\
2012.896\end{array}$ & $\begin{array}{r}100 \\
2 \\
5 \\
100 \\
30\end{array}$ & $\begin{array}{l}49629.1 \\
49642.4 \\
49655.0 \\
49676.7 \\
49679.7\end{array}$ & $\begin{array}{l}14558_{9 / 2}-64235_{9 / 2}^{\circ} \\
25934_{5 / 2}-75614_{5 / 2}^{\circ}\end{array}$ & $\begin{array}{l}1994.027 \\
1993.422 \\
1993.346 \\
1991.983 \\
1991.836\end{array}$ & $\begin{array}{c}20 \\
300 c l \\
100 c l \\
10 \\
6\end{array}$ & $\begin{array}{l}50149.8 \\
50165.0 \\
50166.9 \\
50201.2 \\
50204.9\end{array}$ & $\begin{array}{l}31254_{7 / 2}-81404_{5 / 2}^{\circ} \\
16516_{7 / 2}-66681_{5 / 2}^{\circ} \\
23442_{11 / 2}-73609^{\circ}{ }_{11 / 2} \\
21535_{9 / 2}-71736^{\circ}{ }_{11 / 2} \\
25409_{7 / 2}-75614_{5 / 2}^{\circ}\end{array}$ \\
\hline $\begin{array}{l}2011.593 \\
2011.388 \\
2011.008 \\
\\
2010.696\end{array}$ & $\begin{array}{r}100 \\
3 \\
1\end{array}$ & $\begin{array}{l}49711.8 \\
49716.9 \\
49726.3 \\
49734.0\end{array}$ & $\begin{array}{l}12846_{9 / 2}-62558_{11 / 2}^{\circ} \\
22277_{3 / 2}-71994_{5 / 2}^{\circ} \\
21294_{7 / 2}-71021^{\circ}{ }_{9 / 2}^{\circ} \\
23651_{7 / 2}-73378_{7 / 2}^{\circ}\end{array}$ & $\begin{array}{l}1991.622 \\
1991.509 \\
1991.049 \\
1990.959 \\
1989.646\end{array}$ & $\begin{array}{r}60 \\
30 \\
1 \\
3 \\
50\end{array}$ & $\begin{array}{l}50210.3 \\
50213.2 \\
50224.8 \\
50227.0 \\
50260.2\end{array}$ & $24250_{3 / 2}-74463_{3 / 2}^{\circ}$ \\
\hline $\begin{array}{l}2010.339 \\
2009.905 \\
2009.579 \\
2009.467 \\
2009.177\end{array}$ & $\begin{array}{r}80 \\
80 \\
40 \\
5 \\
40\end{array}$ & $\begin{array}{l}49742.8 \\
49753.6 \\
49761.7 \\
49764.4 \\
49771.6\end{array}$ & $\begin{array}{l}28720_{9 / 2}-78463^{\circ}{ }_{7 / 2} \\
18211_{5 / 2}-67965^{\circ} \\
23844_{9 / 2}-73609^{\circ}{ }_{11 / 2} \\
15045_{5 / 2}-64817_{5 / 2}^{\circ}\end{array}$ & $\begin{array}{l}1989.319 \\
1988.770 \\
1988.707 \\
1988.247 \\
1988.139\end{array}$ & $\begin{array}{r}300 \\
6 \\
2 \\
10 \\
300\end{array}$ & $\begin{array}{l}50268.5 \\
50282.3 \\
50283.9 \\
50295.6 \\
50298.3\end{array}$ & $\begin{array}{l}18063_{9 / 2}-68331_{7 / 2}^{\circ} \\
22747_{9 / 2}-73029_{9 / 2}^{\circ} \\
18241_{11 / 2}-68525_{11 / 2}^{\circ} \\
14558_{9 / 2}-64857_{9 / 2}^{\circ}\end{array}$ \\
\hline
\end{tabular}


TABLE X. Observed spectral lines of Pr III in the vacuum ultra violet region-Continued

\begin{tabular}{|c|c|c|c|c|c|c|c|}
\hline$\lambda_{\text {yac }}$ & Intensity & $\begin{array}{c}\sigma \\
\left(\mathrm{cm}^{-1}\right)\end{array}$ & Classification $^{\text {a }}$ & $\lambda_{\text {yac }}$ & Intensity & $\begin{array}{c}\sigma \\
\left(\mathrm{cm}^{-1}\right)\end{array}$ & Classification $^{\text {a }}$ \\
\hline 1987.631 & 40 & 50311.2 & $18063_{9 / 2}-68374_{9 / 2}^{\circ}$ & 1967.373 & 1 & 50829.2 & \\
\hline 1987.542 & 2 & 50313.4 & & 1967.233 & 1 & 50832.8 & $24461_{5 / 2}-75294_{7 / 2}^{\circ}$ \\
\hline 1985.995 & 5 & 50352.6 & $21148_{3 / 2}-71501_{3 / 2}^{\circ}$ & 1966.710 & 2 & 50846.3 & $21148_{3 / 2}-71994_{5 / 2}^{\circ}$ \\
\hline & & & $25409_{7 / 2}-75762_{9 / 2}^{\circ}$ & 1966.502 & 3 & 50851.7 & $24788_{9 / 2}-75640^{\circ}{ }_{11 / 2}$ \\
\hline 1985.023 & 1 & 50377.2 & $19308_{11 / 2}-69686_{9 / 2}^{\circ}$ & 1966.208 & 40 & 50859.3 & $27604_{9 / 2}-78463^{\circ}{ }_{7 / 2}$ \\
\hline 1984.870 & 10 & 50381.1 & & & & & $36652_{5 / 2}-87511_{7 / 2}^{\circ}$ \\
\hline 1984.698 & 20 & 50385.5 & $12846_{9 / 2}-63232_{7 / 2}^{\circ}$ & 1965.970 & 80 & 50865.5 & $17627_{9 / 2}-68492_{7 / 2}^{\circ}$ \\
\hline 1984.380 & 4 & 50393.6 & & 1965.346 & 1 & 50881.6 & \\
\hline 1984.348 & $2 c l$ & 50394.4 & & 1963.974 & 2 & 50917.2 & $17627_{9 / 2}-68544_{9 / 2}^{\circ}$ \\
\hline 1984.250 & 50 & 50396.9 & $15525_{11 / 2}-65922^{\circ}{ }_{11 / 2}$ & 1963.911 & 2 & 50918.8 & \\
\hline 1983.311 & 10 & 50420.7 & $14558_{9 / 2}-64979_{7 / 2}^{\circ}$ & 1963.786 & $100 \mathrm{cl}$ & 50922.0 & $12846_{9 / 2}-63768_{7 / 2}^{\circ}$ \\
\hline 1983.066 & 2 & 50427.0 & $16516_{7 / 2}-66943_{5 / 2}^{\circ}$ & 1963.731 & $20 \mathrm{cl}$ & 50923.5 & $18063_{9 / 2}-68987_{7 / 2}^{\circ}$ \\
\hline 1982.981 & 300 & 50429.1 & $18063_{9 / 2}-68492_{7 / 2}^{\circ}$ & 1963.401 & 100 & 50932.0 & \\
\hline 1982.785 & 2 & 50434.1 & $23175_{13 / 2}-73609^{\circ}{ }_{11 / 2}$ & 1962.747 & 4 & 50949.0 & $22080_{7 / 2}-73029_{9 / 2}^{\circ}$ \\
\hline 1982.492 & 5 & 50441.6 & $15525_{11 / 2}-65967^{\circ}{ }_{13 / 2}$ & 1962.418 & 10 & 50957.5 & $25934_{5 / 2}-76892_{3 / 2}^{\circ}$ \\
\hline 1982.428 & 1 & 50443.2 & $21535_{9 / 2}-71978_{7 / 2}^{\circ}$ & 1961.929 & 200 & 50970.2 & $12846_{9 / 2}-63816_{11 / 2}^{\circ}$ \\
\hline 1981.580 & 100 & 50464.8 & $13352_{11 / 2}-63816_{11 / 2}^{\circ}$ & 1961.265 & 3 & 50987.5 & \\
\hline 1981.449 & 2 & 50468.1 & $15454_{13 / 2}-65922_{11 / 2}^{\circ}$ & 1960.735 & 10 & 51001.3 & \\
\hline 1981.140 & 4 & 50476.0 & & 1959.961 & 30 & 51021.4 & $19360_{13 / 2}-70381_{13 / 2}^{\circ}$ \\
\hline 1980.950 & 10 & 50480.8 & $18063_{9 / 2}-68544_{9 / 2}^{\circ}$ & 1959.874 & $10 b l$ & 51023.7 & $45807_{5 / 2}-96830_{7 / 2}^{\circ}$ \\
\hline 1980.867 & 2 & 50483.0 & $30505_{11 / 2}-80988^{\circ}{ }_{13 / 2}$ & 1958.687 & 2 & 51054.6 & $23050_{3 / 2}-74105_{5 / 2}^{\circ}$ \\
\hline 1980.287 & 200 & 50497.7 & & 1958.387 & 100 & 51062.4 & $14859_{11 / 2}-65922_{11 / 2}^{\circ}$ \\
\hline 1980.191 & $100 h$ & 50500.2 & $38448_{9 / 2}-88948_{9 / 2}^{\circ}$ & 1958.053 & 2 & 51071.1 & \\
\hline 1979.745 & $5 b l$ & 50511.6 & & 1958.001 & 1 & 51072.5 & $19308_{11 / 2}-70381^{\circ}{ }_{13 / 2}$ \\
\hline 1979.692 & 20 & 50512.9 & $15454_{13 / 2}-65967^{\circ}{ }_{13 / 2}$ & 1957.908 & 3 & 51074.9 & $18063_{9 / 2}-69138_{9 / 2}^{\circ}$ \\
\hline 1978.427 & 200 & 50545.2 & $16135_{7 / 2}-66681_{5 / 2}^{\circ}$ & 1957.338 & 1 & 51089.8 & $24470_{7 / 2}-75560_{5 / 2}^{\circ}$ \\
\hline 1975.850 & 2 & 50611.1 & $17627_{9 / 2}-68238_{11 / 2}^{\circ}$ & 1957.073 & 6 & 51096.7 & \\
\hline 1975.782 & 4 & 50612.9 & & 1957.039 & 3 & 51097.6 & $29263_{13 / 2}-80360_{11 / 2}^{\circ}$ \\
\hline 1975.582 & 200 & 50618.0 & $19360_{13 / 2}-69978_{11 / 2}^{\circ}$ & 1956.957 & 20 & 51099.7 & $24461_{5 / 2}-75560_{5 / 2}^{\circ}$ \\
\hline 1975.424 & 3 & 50622.0 & & 1956.672 & 5 & 51107.2 & $14859_{11 / 2}-65967_{13 / 2}^{\circ}$ \\
\hline 1973.849 & 3 & 50662.4 & & 1955.992 & 15 & 51124.9 & $1713_{13 / 2}-68238_{11 / 2}^{\circ}$ \\
\hline 1973.590 & 2 & 50669.1 & $19308_{11 / 2}-69978_{11 / 2}^{\circ}$ & 1955.521 & 3 & 51137.3 & \\
\hline 1973.367 & 10 & 50674.8 & $28720_{9 / 2}-79395^{\circ}{ }_{7 / 2}$ & 1955.268 & 3 & 51143.9 & $24470_{7 / 2}-75614_{5 / 2}^{\circ}$ \\
\hline 1972.857 & 10 & 50687.9 & $20848_{5 / 2}-71536_{5 / 2}^{\circ}$ & 1954.535 & 10 & 51163.1 & $16516_{7 / 2}-67679^{\circ}{ }_{7 / 2}$ \\
\hline 1972.617 & 5 & 50694.1 & $15454_{13 / 2}-66148_{13 / 2}^{\circ}$ & 1954.455 & $60 w$ & 51165.2 & \\
\hline 1972.200 & 30 & 50704.8 & $17627_{9 / 2}-68331_{7 / 2}^{\circ}$ & 1954.386 & 20 & 51167.0 & $18241_{11 / 2}-69408_{11 / 2}^{\circ}$ \\
\hline 1971.913 & 2 & 50712.2 & & 1954.196 & 40 & 51171.9 & \\
\hline 1971.730 & 15 & 50716.9 & $16135_{7 / 2}-66852_{7 / 2}^{\circ}$ & 1954.092 & 2 & 51174.7 & $17627_{9 / 2}-68801_{7 / 2}^{\circ}$ \\
\hline 1971.636 & 200 & 50719.3 & & 1953.531 & 20 & 51189.4 & \\
\hline 1971.287 & 4 & 50728.3 & $25033_{9 / 2}-75762_{9 / 2}^{\circ}$ & 1953.321 & 5 & 51194.9 & \\
\hline 1971.248 & 4 & 50729.3 & & 1952.395 & 1 & 51219.1 & $18211_{5 / 2}-69431^{\circ} / 2$ \\
\hline 1970.573 & 80 & 50746.7 & $12846_{9 / 2}-63593_{9 / 2}^{\circ}$ & 1951.968 & 2 & 51230.3 & \\
\hline 1970.091 & 1 & 50759.1 & $39870_{9 / 2}-90629_{9 / 2}^{\circ}$ & 1951.018 & $200 \mathrm{bl}$ & 51255.3 & \\
\hline 1969.791 & 40 & 50766.8 & $18211_{5 / 2}-68978_{5 / 2}^{\circ}$ & 1950.864 & 1 & 51259.3 & $16135_{7 / 2}-67395_{5 / 2}^{\circ}$ \\
\hline 1969.650 & 20 & 50770.4 & $17534_{15 / 2}-68305_{15 / 2}^{\circ}$ & 1949.759 & 100 & 51288.4 & $14859_{11 / 2}-66148_{13 / 2}^{\circ}$ \\
\hline 1969.468 & 10 & 50775.1 & $18211_{5 / 2}-68987_{7 / 2}^{\circ}$ & 1949.156 & 60 & 51304.3 & $12846_{9 / 2}-64150^{\circ}{ }_{11 / 2}$ \\
\hline 1968.530 & 60 & 50799.3 & & 1948.364 & 10 & 51325.1 & $27138_{7 / 2}-78463_{7 / 2}^{\circ}$ \\
\hline 1968.227 & 40 & 50807.2 & $16135_{7 / 2}-66943_{5 / 2}^{\circ}$ & 1947.036 & 10 & 51360.1 & $17627_{9 / 2}-68987^{\circ}{ }_{7 / 2}$ \\
\hline 1967.608 & 10 & 50823.1 & $24470_{7 / 2}-75294_{7 / 2}^{\circ}$ & 1946.900 & 1 & 51363.7 & $14558_{9 / 2}-65922^{\circ}{ }_{11 / 2}$ \\
\hline 1967.447 & 20 & 50827.3 & & 1946.830 & 3 & 51365.6 & \\
\hline
\end{tabular}


TABLE X. Observed spectral lines of $\mathrm{Pr}$ III in the vacuum ultra violet region-Continued

\begin{tabular}{|c|c|c|c|c|c|c|c|}
\hline$\lambda_{\mathrm{yac}}$ & Intensity & $\begin{array}{c}\sigma \\
\left(\mathrm{cm}^{-1}\right)\end{array}$ & Classification $^{\text {a }}$ & $\lambda_{\text {yac }}$ & Intensity & $\begin{array}{c}\sigma \\
\left(\mathrm{cm}^{-1}\right)\end{array}$ & Classification $^{\text {a }}$ \\
\hline 1946.417 & 80 & 51376.4 & $14558_{9 / 2}-65935_{7 / 2}^{\circ}$ & & & & $23532_{5 / 2}-75560_{5 / 2}^{\circ}$ \\
\hline 1945.646 & 2 & 51396.8 & & 1921.828 & 2 & 52033.8 & \\
\hline 1945.053 & 1 & 51412.5 & $1713_{13 / 2}-68525_{11 / 2}^{\circ}$ & 1921.763 & 50 & 52035.6 & $19700_{11 / 2}-71736_{11 / 2}^{\circ}$ \\
\hline 1943.835 & 8 & 51444.7 & $18241_{11 / 2}-69686_{9 / 2}^{\circ}$ & 1920.869 & 1 & 52059.8 & \\
\hline 1943.650 & 4 & 51449.6 & $23844_{9 / 2}-75294_{7 / 2}^{\circ}$ & 1919.639 & 1 & 52093.1 & \\
\hline 1943.293 & 10 & 51459.0 & & 1919.162 & 30 & 52106.1 & $19872_{7 / 2}-71978_{7 / 2}^{\circ}$ \\
\hline 1943.248 & 30 & 51460.2 & $18921_{15 / 2}-70381_{13 / 2}^{\circ}$ & 1918.562 & 100 & 52122.4 & $19872_{7 / 2}-71994_{5 / 2}^{\circ}$ \\
\hline 1941.939 & 2 & 51494.9 & $21535_{9 / 2}-73029_{9 / 2}^{\circ}$ & 1917.201 & 1 & 52159.4 & \\
\hline 1941.556 & 100 & 51505.1 & $13352_{11 / 2}-64857_{9 / 2}^{\circ}$ & 1916.741 & 4 & 52171.9 & $31254_{7 / 2}-83426_{5 / 2}^{\circ}$ \\
\hline 1941.250 & 2 & 51513.2 & $13352_{11 / 2}-64865_{11 / 2}^{\circ}$ & 1916.507 & 1 & 52178.3 & \\
\hline 1940.930 & 2 & 51521.7 & & 1916.106 & 50 & 52189.2 & $14859_{11 / 2}-67049_{9 / 2}^{\circ}$ \\
\hline 1940.853 & 5 & 51523.7 & $15525_{11 / 2}-67049_{9 / 2}^{\circ}$ & 1915.296 & 1 & 52211.2 & \\
\hline 1940.770 & 2 & 51525.9 & & 1914.681 & 2 & 52228.0 & $27138_{7 / 2}-79366_{5 / 2}^{\circ}$ \\
\hline 1939.299 & 100 & 51565.0 & & 1913.964 & 70 & 52247.6 & \\
\hline 1939.161 & 10 & 51568.7 & & 1913.622 & 1 & 52256.9 & $27138_{7 / 2}-79395_{7 / 2}^{\circ}$ \\
\hline 1937.726 & 20 & 51606.9 & & 1913.339 & 2 & 52264.6 & \\
\hline 1937.127 & 10 & 51622.8 & $18063_{9 / 2}-69686_{9 / 2}^{\circ}$ & 1913.284 & $100 \mathrm{bl}$ & 52266.2 & \\
\hline 1936.659 & 40 & 51635.3 & $15045_{5 / 2}-66681_{5 / 2}^{\circ}$ & 1912.698 & 5 & 52282.2 & \\
\hline 1936.478 & 3 & 51640.1 & $28720_{9 / 2}-80360^{\circ}{ }_{11 / 2}$ & 1912.651 & 20 & 52283.4 & $19308_{11 / 2}-71592_{9 / 2}^{\circ}$ \\
\hline 1936.375 & 1 & 51642.9 & & 1911.251 & 3 & 52321.8 & \\
\hline 1935.588 & 30 & 51663.9 & $19872_{7 / 2}-71536_{5 / 2}^{\circ}$ & 1910.242 & 2 & 52349.4 & $15045_{5 / 2}-67395_{5 / 2}^{\circ}$ \\
\hline 1935.290 & 1 & 51671.8 & $38448_{9 / 2}-90119^{\circ}{ }_{11 / 2}$ & 1910.093 & 1 & 52353.5 & \\
\hline 1933.865 & 10 & 51709.9 & $35801_{7 / 2}-87511_{7 / 2}^{\circ}$ & 1909.895 & 3 & 52358.9 & $23050_{3 / 2}-75409_{3 / 2}^{\circ}$ \\
\hline 1933.775 & 100 & 51712.3 & $19308_{11 / 2}-71021_{9 / 2}^{\circ}$ & 1909.471 & 200 & 52370.5 & $21238_{13 / 2}-73609_{11 / 2}^{\circ}$ \\
\hline 1933.491 & 1 & 51719.9 & $19872_{7 / 2}-71592_{9 / 2}^{\circ}$ & 1909.258 & 300 & 52376.4 & $19360_{13 / 2}-71736_{11 / 2}^{\circ}$ \\
\hline 1932.872 & 8 & 51736.5 & $18241_{11 / 2}-69978_{11 / 2}^{\circ}$ & 1907.956 & 4 & 52412.1 & $25409_{7 / 2}-77822_{5 / 2}^{\circ}$ \\
\hline 1932.181 & $5 b l$ & 51755.0 & & 1907.054 & 10 & 52436.9 & \\
\hline 1931.739 & 5 & 51766.8 & $21611_{5 / 2}-73378_{7 / 2}^{\circ}$ & 1906.750 & $10 \mathrm{bl}$ & 52445.3 & \\
\hline 1931.368 & 1 & 51776.8 & & 1906.126 & 2 & 52462.4 & $16516_{7 / 2}-68978_{5 / 2}^{\circ}$ \\
\hline 1930.813 & 40 & 51791.6 & & 1906.040 & 40 & 52464.8 & $23175_{13 / 2}-75640^{\circ}{ }_{11 / 2}$ \\
\hline 1930.349 & 10 & 51804.1 & $17627_{9 / 2}-69431_{7 / 2}^{\circ}$ & 1905.819 & $20 h$ & 52470.9 & $16516_{7 / 2}-68987_{7 / 2}^{\circ}$ \\
\hline 1930.001 & 3 & 51813.4 & & 1905.688 & 10 & 52474.5 & \\
\hline 1929.920 & 20 & 51815.6 & $16516_{7 / 2}-68331_{7 / 2}^{\circ}$ & 1904.981 & 1 & 52494.0 & $21611_{5 / 2}-74105_{5 / 2}^{\circ}$ \\
\hline 1929.706 & 30 & 51821.4 & $15045_{5 / 2}-66867_{3 / 2}^{\circ}$ & 1904.862 & 3 & 52497.2 & \\
\hline 1928.246 & 7 & 51860.6 & & 1904.625 & 1 & 52503.8 & \\
\hline 1927.821 & 20 & 51872.0 & & 1904.212 & 4 & 52515.2 & \\
\hline 1927.774 & 20 & 51873.3 & $15525_{11 / 2}-67398_{9 / 2}^{\circ}$ & 1903.356 & 60 & 52538.8 & $14859_{11 / 2}-67398_{9 / 2}^{\circ}$ \\
\hline 1927.678 & 4 & 51875.9 & $14859_{11 / 2}-66735_{13 / 2}^{\circ}$ & 1903.115 & $10 \mathrm{cl}$ & 52545.4 & \\
\hline 1927.095 & 300 & 51891.6 & $19700_{11 / 2}-71592_{9 / 2}^{\circ}$ & 1903.083 & $10 c l$ & 52546.3 & $18990_{7 / 2}-71536_{5 / 2}^{\circ}$ \\
\hline 1926.884 & 3 & 51897.3 & $15045_{5 / 2}-66943_{5 / 2}^{\circ}$ & 1902.215 & 2 & 52570.3 & $13352_{11 / 2}-65922^{\circ}{ }_{11 / 2}$ \\
\hline 1925.579 & $3 b l$ & 51932.4 & & 1901.979 & 4 & 52576.8 & \\
\hline 1925.184 & 10 & 51943.1 & $27452_{5 / 2}-79395^{\circ} / 2$ & 1901.715 & 7 & 52584.1 & \\
\hline 1924.451 & 30 & 51962.9 & $23651_{7 / 2}-75614_{5 / 2}^{\circ / 2}$ & 1900.811 & 5 & 52609.1 & \\
\hline 1923.365 & 300 & 51992.2 & $23647_{13 / 2}-75640^{\circ}{ }_{11 / 2}$ & 1900.561 & 1 & 52616.0 & \\
\hline 1923.154 & 2 & 51997.9 & & 1899.627 & 1 & 52641.9 & $24250_{3 / 2}-76892_{3 / 2}^{\circ}$ \\
\hline 1922.689 & 200 & 52010.5 & $12846_{9 / 2}-64857_{9 / 2}^{\circ}$ & 1899.491 & 5 & 52645.7 & \\
\hline 1922.459 & 3 & 52016.7 & $26446_{7 / 2}-78463_{7 / 2}^{\circ}$ & 1898.200 & 80 & 52681.5 & $14558_{9 / 2}-67240_{7 / 2}^{\circ}$ \\
\hline 1922.394 & 1 & 52018.5 & $12846_{9 / 2}-64865^{\circ}{ }_{11 / 2}$ & 1898.020 & 5 & 52686.5 & $21418_{5 / 2}-74105_{5 / 2}^{\circ}$ \\
\hline 1922.178 & 20 & 52024.3 & $22080_{7 / 2}-74105_{5 / 2}^{\circ}$ & & & & $34825_{7 / 2}-87511_{7 / 2}^{\circ}$ \\
\hline 1922.047 & 10 & 52027.9 & $16516_{7 / 2}-68544_{9 / 2}^{\circ}$ & 1897.082 & 1 & 52712.5 & $15525_{11 / 2}-68238^{\circ}{ }_{11 / 2}$ \\
\hline
\end{tabular}


TABLE X. Observed spectral lines of Pr III in the vacuum ultra violet region-Continued

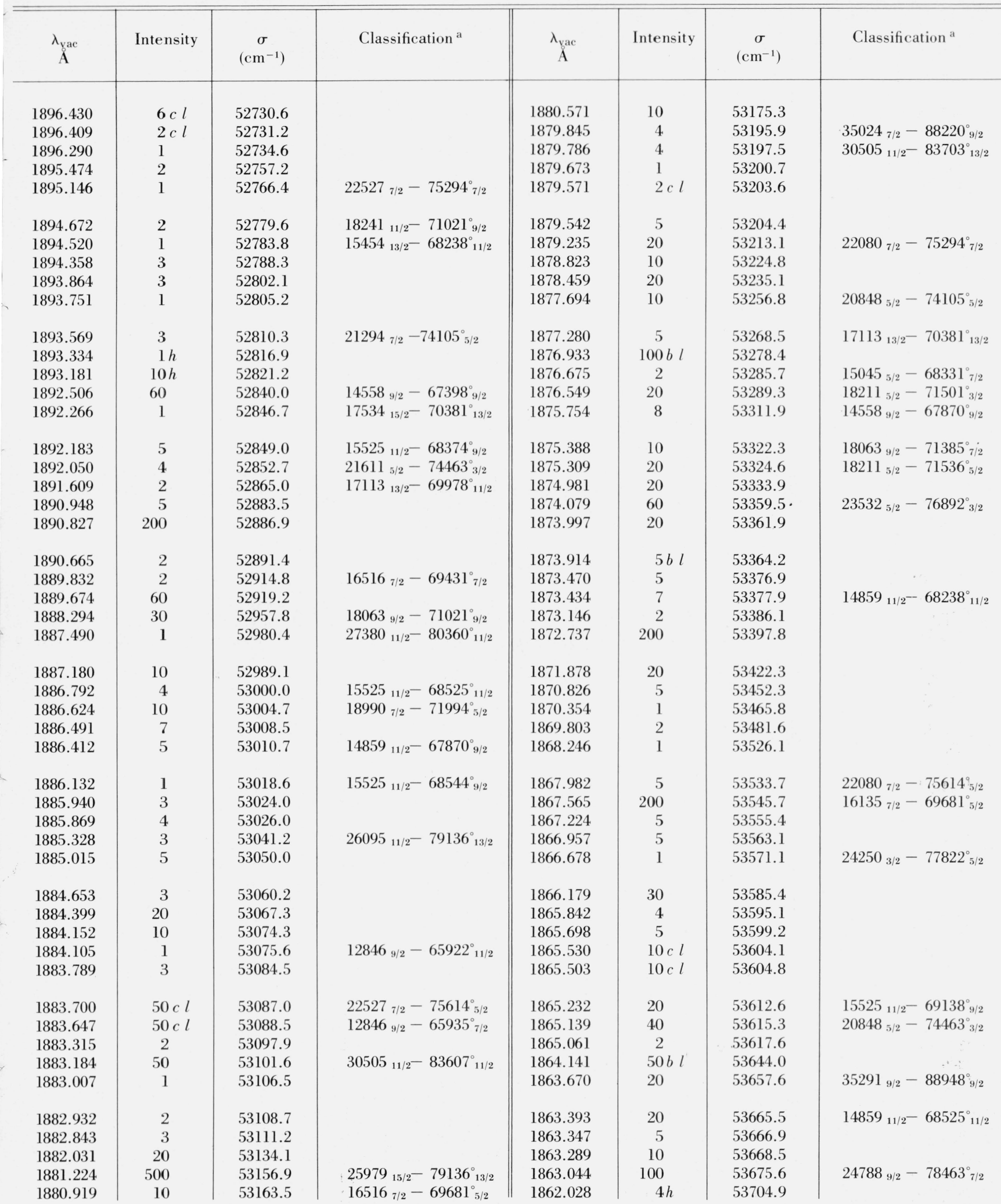

a For doubly-classified lines, the wavelength is entered only once. 
TABLE X. Observed spectral lines of Pr III in the vacuum ultra violet region-Continued

\begin{tabular}{|c|c|c|c|c|c|c|c|}
\hline$\lambda_{\mathrm{yac}}$ & Intensity & $\begin{array}{c}\sigma \\
\left(\mathrm{cm}^{-1}\right)\end{array}$ & Classification $^{\mathrm{a}}$ & $\lambda_{\mathrm{vac}}$ & Intensity & $\begin{array}{c}\sigma \\
\left(\mathrm{cm}^{-1}\right)\end{array}$ & Classification $^{a}$ \\
\hline 1861.467 & 60 & 53721.1 & $19308_{11 / 2}-73029_{9 / 2}^{\circ}$ & 1843.574 & 4 & 54242.5 & \\
\hline 1861.040 & 10 & 53733.4 & & 1843.356 & 10 & 54248.9 & $19360_{13 / 2}-73609^{\circ}{ }_{11 / 2}$ \\
\hline 1860.876 & 30 & 53738.1 & & 1842.950 & 10 & 54260.8 & $21148_{3 / 2}-75409^{\circ}{ }_{3 / 2}$ \\
\hline 1860.257 & 10 & 53756.0 & $15045_{5 / 2}-68801_{7 / 2}^{\circ}$ & 1842.789 & 200 & 54265.6 & $21294_{7 / 2}-75560_{5 / 2}^{\circ}$ \\
\hline 1860.167 & 100 & 53758.6 & $17627_{9 / 2}-71385^{\circ}$ & & & & $26095_{11 / 2}-80360_{11 / 2}^{\circ}$ \\
\hline & & & $21535_{9 / 2}-75294^{\circ}{ }^{\circ / 2}$ & 1842.365 & 60 & 54278.1 & $14859_{11 / 2}-69138_{9 / 2}^{\circ}$ \\
\hline 1859.679 & $40 h$ & 53772.7 & $14558_{9 / 2}-68331_{7 / 2}^{\circ}$ & 1842.235 & 5 & 54281.9 & \\
\hline 1859.328 & 5 & 53782.9 & $18211_{5 / 2}-71994_{5 / 2}^{\circ}$ & 1841.926 & 1 & 54291.0 & $35828_{9 / 2}-90119_{11 / 2}^{\circ}$ \\
\hline 1859.270 & 5 & 53784.6 & & 1841.729 & 2 & 54296.8 & \\
\hline 1858.198 & 10 & 53815.6 & $14558_{9 / 2}-68374_{9 / 2}^{\circ}$ & 1841.514 & 6 & 54303.1 & $20160_{3 / 2}-74463_{3 / 2}^{\circ}$ \\
\hline 1857.791 & $5 w$ & 53827.4 & & 1841.463 & 2 & 54304.6 & \\
\hline 1857.615 & 5 & 53832.5 & & 1841.311 & 2 & 54309.1 & \\
\hline 1857.212 & 10 & 53844.1 & & 1840.954 & $10 c l$ & 54319.7 & $21294_{7 / 2}-75614_{5 / 2}^{\circ}$ \\
\hline 1857.044 & $1 h$ & 53849.0 & & 1840.585 & 1 & 54330.6 & \\
\hline 1856.931 & 1 & 53852.3 & & 1840.136 & 3 & 54343.8 & \\
\hline 1856.144 & 10 & 53875.1 & $21418_{5 / 2}-75294_{7 / 2}^{\circ}$ & 1839.547 & 2 & 54361.2 & \\
\hline 1856.053 & 10 & 53877.8 & & 1838.456 & 200 & 54393.5 & $12846_{9 / 2}-67240_{7 / 2}^{\circ}$ \\
\hline 1855.878 & $10 c l$ & 53882.8 & $15525_{11 / 2}-69408_{11 / 2}^{\circ}$ & 1838.198 & 50 & 54401.1 & $21238_{13 / 2}-75640^{\circ}{ }_{11 / 2}$ \\
\hline 1855.601 & 2 & 53890.9 & & 1837.984 & 20 & 54407.4 & \\
\hline 1855.511 & $10 h$ & 53893.5 & & 1837.352 & 3 & 54426.2 & \\
\hline 1855.117 & 3 & 53905.0 & $30505_{11 / 2}-84410_{9 / 2}^{\circ}$ & 1837.311 & 1 & 54427.4 & \\
\hline 1855.004 & 30 & 53908.2 & $19700_{11 / 2}-73609^{\circ}{ }_{11 / 2}$ & 1837.189 & 2 & 54431.0 & \\
\hline 1854.181 & $5 c l$ & 53932.2 & & 1837.074 & 6 & 54434.4 & \\
\hline 1853.958 & $10 h$ & 53938.6 & & 1836.887 & 3 & 54439.9 & \\
\hline 1853.754 & 1 & 53944.6 & $20160_{3 / 2}-74105_{5 / 2}^{\circ}$ & 1836.705 & 3 & 54445.3 & $20848_{5 / 2}-75294_{7 / 2}^{\circ}$ \\
\hline 1853.326 & 4 & 53957.0 & $25409_{7 / 2}-79366_{5 / 2}^{\circ}$ & 1836.635 & 5 & 54447.4 & \\
\hline 1853.288 & 4 & 53958.2 & & 1836.471 & 7 & 54452.3 & $15525_{11 / 2}-69978_{11 / 2}^{\circ}$ \\
\hline 1853.078 & 4 & 53964.3 & & 1835.696 & 2 & 54475.2 & \\
\hline 1852.481 & 2 & 53981.7 & & 1835.657 & 1 & 54476.4 & \\
\hline 1852.409 & $2 h$ & 53983.8 & & 1835.219 & 1 & 54489.4 & \\
\hline 1851.891 & 1 & 53998.8 & $21294_{7 / 2}-75294^{\circ}{ }_{7 / 2}$ & 1834.398 & 8 & 54513.8 & \\
\hline 1850.099 & 8 & 54051.2 & $31254_{7 / 2}-85306_{5 / 2}^{\circ}$ & 1833.240 & 100 & 54548.2 & \\
\hline 1849.381 & 10 & 54072.1 & & 1833.120 & 100 & 54551.8 & \\
\hline 1849.277 & 2 & 54075.2 & & 1832.466 & 2 & 54571.3 & \\
\hline 1848.358 & 4 & 54.102 .1 & & 1832.331 & 15 & 54575.3 & $29835_{9 / 2}-84410_{9 / 2}^{\circ}$ \\
\hline 1848.161 & 2 & 54107.8 & & 1831.264 & 4 & 54607.1 & \\
\hline 1847.484 & 10 & 54127.7 & & 1831.212 & 8 & 54608.6 & \\
\hline 1847.308 & $10 b l$ & 54132.8 & & 1830.872 & 50 & 54618.8 & $23844_{9 / 2}-78463^{\circ}{ }_{7 / 2}$ \\
\hline 1847.196 & $20 c l$ & 54136.1 & & 1830.727 & 1 & 54623.1 & $17113_{13 / 2}-71736_{11 / 2}^{\circ}$ \\
\hline 1847.167 & 2 & 54137.0 & & 1830.593 & $100 h$ & 54627.1 & \\
\hline 1847.014 & 10 & 54141.4 & & 1830.311 & 20 & 54635.5 & $15045_{7 / 2}-69681_{5 / 2}^{\circ}$ \\
\hline 1846.935 & 20 & 54143.8 & & 1829.742 & $10 h$ & 54652.5 & \\
\hline 1846.836 & 40 & 54146.6 & & 1829.313 & $100 h$ & 54665.3 & \\
\hline 1846.378 & 20 & 54160.1 & & 1828.849 & $5 b l$ & 54679.2 & \\
\hline 1846.187 & 6 & 54165.7 & & 1828.589 & 1 & 54687.0 & \\
\hline 1845.896 & 1 & 54174.2 & & 1828.196 & 2 & 54698.7 & $78694^{\circ} 11 / 2-133393_{13 / 2}$ \\
\hline 1844.951 & 2 & 54202.0 & & 1828.045 & 2 & 54703.2 & \\
\hline 1844.862 & 3 & 54204.6 & & 1827.758 & 4 & 54711.8 & \\
\hline 1844.590 & 1 & 54212.6 & & 1826.966 & 10 & 54735.6 & \\
\hline 1843.910 & 20 & 54232.6 & $19872_{7 / 2}-74105_{5 / 2}^{\circ}$ & 1825.989 & 2 & 54764.8 & \\
\hline
\end{tabular}


TABLE X. Observed spectral lines of Pr III in the vacuum ultra violet region-Continued

\begin{tabular}{|c|c|c|c|c|c|c|c|}
\hline$\lambda_{\mathrm{vac}}$ & Intensity & $\begin{array}{c}\sigma \\
\left(\mathrm{cm}^{-1}\right)\end{array}$ & Classification $^{\text {a }}$ & $\lambda_{\mathrm{vac}}$ & Intensity & $\begin{array}{c}\sigma \\
\left(\mathrm{cm}^{-1}\right)\end{array}$ & Classification $^{\text {a }}$ \\
\hline $\begin{array}{l}1771.958 \\
1771.680 \\
1771.545 \\
1771.483 \\
1771.328\end{array}$ & $\begin{array}{r}4 \\
1 \\
15 \\
10 \\
4\end{array}$ & $\begin{array}{l}56434.7 \\
56443.6 \\
56447.9 \\
56449.9 \\
56454.8\end{array}$ & & $\begin{array}{l}1740.056 \\
1739.840 \\
1738.971 \\
1737.972 \\
1736.996\end{array}$ & $\begin{array}{c}1 \\
200 \\
30 \\
5 h \\
10\end{array}$ & $\begin{array}{l}57469.4 \\
57476.6 \\
57505.3 \\
57538.3 \\
57570.6\end{array}$ & \\
\hline $\begin{array}{l}1769.398 \\
1769.064 \\
1768.618 \\
1768.479 \\
1768.114\end{array}$ & $\begin{array}{r}100 \\
20 \\
7 \\
10 \\
5\end{array}$ & $\begin{array}{l}56516.4 \\
56527.1 \\
56541.3 \\
56545.8 \\
56557.4\end{array}$ & $\begin{array}{l}23844_{9 / 2}-80360^{\circ}{ }_{11 / 2} \\
21294_{7 / 2}-77822^{\circ}{ }_{5 / 2}\end{array}$ & $\begin{array}{l}1736.747 \\
1736.646 \\
1735.801 \\
1735.757 \\
1734.029\end{array}$ & $\begin{array}{r}5 \\
200 \\
4 \\
1 \\
2\end{array}$ & $\begin{array}{l}57578.9 \\
57582.2 \\
57610.3 \\
57611.8 \\
57669.2\end{array}$ & $13352_{11 / 2}-71021_{9 / 2}^{\circ}$ \\
\hline $\begin{array}{l}1766.432 \\
1765.543 \\
1765.299 \\
1765.087 \\
1764.859\end{array}$ & $\begin{array}{c}3 \\
2 \\
1 \\
4 \\
10 h\end{array}$ & $\begin{array}{l}56611.3 \\
56639.8 \\
56647.6 \\
56654.4 \\
56661.7\end{array}$ & $\begin{array}{l}22277_{3 / 2}-78889^{\circ}{ }_{3 / 2} \\
22747_{9 / 2}-79395^{\circ}{ }_{7 / 2} \\
36642_{13 / 2}-93296^{\circ}{ }_{11 / 2}\end{array}$ & $\begin{array}{l}1732.382 \\
1731.526 \\
1731.442 \\
1729.702 \\
1728.302\end{array}$ & $\begin{array}{r}20 \\
2 \\
2 \\
3 \\
1\end{array}$ & $\begin{array}{l}57724.0 \\
57752.5 \\
57755.3 \\
57813.4 \\
57860.3\end{array}$ & $\begin{array}{l}25979_{15 / 2}-83703_{13 / 2}^{\circ} \\
23651_{7 / 2}-81404^{\circ}{ }_{5 / 2}^{\circ} \\
21611_{5 / 2}-79366_{5 / 2}^{\circ} \\
23175_{13 / 2}-80988^{\circ}{ }_{13 / 2} \\
21535_{9 / 2}-79395^{\circ}{ }_{7 / 2}\end{array}$ \\
\hline $\begin{array}{l}1763.122 \\
1763.005 \\
1762.665 \\
1761.668 \\
1761.052\end{array}$ & $\begin{array}{r}20 \\
1 \\
7 \\
20 \\
2\end{array}$ & $\begin{array}{l}56717.6 \\
56721.3 \\
56732.3 \\
56764.4 \\
56784.2\end{array}$ & $14859_{11 / 2}-71592_{9 / 2}^{\circ}$ & $\begin{array}{l}1727.281 \\
1727.194 \\
1725.553 \\
1724.116 \\
1723.641\end{array}$ & $\begin{array}{l}1 \\
1 \\
3 b l \\
1 \\
10\end{array}$ & $\begin{array}{l}57894.4 \\
57897.4 \\
57952.4 \\
58000.7 \\
58016.7\end{array}$ & $21238_{13 / 2}-79136_{13 / 2}$ \\
\hline $\begin{array}{l}1760.859 \\
1760.518 \\
1759.916 \\
1759.318 \\
1759.278\end{array}$ & $\begin{array}{l}10 \\
10 h \\
1 \\
30 \\
10 c l\end{array}$ & $\begin{array}{l}56790.5 \\
56801.5 \\
56820.9 \\
56840.2 \\
56841.5\end{array}$ & & $\begin{array}{l}1722.693 \\
1722.011 \\
1721.800 \\
1721.473 \\
1721.102\end{array}$ & $\begin{array}{c}2 \\
15 \\
1 \\
1 \\
5 h\end{array}$ & $\begin{array}{l}58048.6 \\
58071.6 \\
58078.8 \\
58089.8 \\
58102.3\end{array}$ & $21294_{7 / 2}-79366_{5 / 2}^{\circ}$ \\
\hline $\begin{array}{l}1758.351 \\
1758.277 \\
1758.196 \\
1755.522 \\
1755.445\end{array}$ & $\begin{array}{r}5 \\
1 \\
7 \\
20 \\
4\end{array}$ & $\begin{array}{l}56871.5 \\
56873.9 \\
56876.5 \\
56963.1 \\
56965.6\end{array}$ & $\begin{array}{l}14859_{11 / 2}-71736^{\circ}{ }_{11 / 2} \\
31254_{7 / 2}-88220_{9 / 2}^{\circ}\end{array}$ & $\begin{array}{l}1720.034 \\
1719.940 \\
1717.770 \\
1717.152 \\
1715.471\end{array}$ & $\begin{array}{r}2 \\
4 \\
200 \\
1 \\
5\end{array}$ & $\begin{array}{l}58138.4 \\
58141.6 \\
58215.0 \\
58236.0 \\
58293.0\end{array}$ & $30733_{11 / 2}-88948_{9 / 2}^{\circ}$ \\
\hline $\begin{array}{l}1754.934 \\
1754.583 \\
1753.297 \\
1750.486 \\
1750.462\end{array}$ & $\begin{array}{l}10 h \\
200 \\
10 \\
5 c l \\
5 c l\end{array}$ & $\begin{array}{l}56982.2 \\
56993.6 \\
57035.4 \\
57127.0 \\
57127.8\end{array}$ & $71978_{7 / 2}^{\circ}-129106_{9 / 2}$ & $\begin{array}{l}1713.147 \\
1712.848 \\
1712.381 \\
1712.058 \\
1711.408\end{array}$ & $\begin{array}{c}4 \\
60 h \\
1 \\
1 \\
2 h\end{array}$ & $\begin{array}{l}58372.1 \\
58382.3 \\
58398.2 \\
58409.2 \\
58431.4\end{array}$ & $38448_{9 / 2}-96830_{7 / 2}^{\circ}$ \\
\hline $\begin{array}{l}1749.160 \\
1748.330 \\
1747.949 \\
1746.225 \\
1745.879\end{array}$ & $\begin{array}{r}2 \\
5 \\
100 \\
1 \\
3\end{array}$ & $\begin{array}{l}57170.3 \\
57197.4 \\
57209.9 \\
57266.4 \\
57277.7\end{array}$ & $35384_{5 / 2}-92554_{5 / 2}^{\circ}$ & $\begin{array}{l}1710.139 \\
1709.377 \\
1707.514 \\
1706.743 \\
1705.705\end{array}$ & $\begin{array}{l}2 \\
5 h \\
1 \\
10 \\
50 h\end{array}$ & $\begin{array}{l}58474.8 \\
58500.8 \\
58564.7 \\
58591.1 \\
58626.8\end{array}$ & $\begin{array}{l}24461_{5 / 2}-83025_{3 / 2}^{\circ} \\
19872_{7 / 2}-78463^{\circ} \\
28885_{9 / 2}^{\circ}-87511_{7 / 2}^{\circ}\end{array}$ \\
\hline $\begin{array}{l}1745.474 \\
1745.329 \\
1744.571 \\
1743.957 \\
1743.758\end{array}$ & $\begin{array}{c}10 h \\
2 \\
4 \\
3 \\
1\end{array}$ & $\begin{array}{l}57291.0 \\
57295.8 \\
57320.7 \\
57340.9 \\
57347.4\end{array}$ & $23647_{13 / 2}-80988^{\circ}{ }_{13 / 2}$ & $\begin{array}{l}1702.266 \\
1700.952 \\
1700.128 \\
1699.416 \\
1698.689\end{array}$ & $\begin{array}{r}1 \\
20 \\
1 \\
3 \\
10\end{array}$ & $\begin{array}{l}58745.2 \\
58790.6 \\
58819.1 \\
58843.7 \\
58868.9\end{array}$ & $\begin{array}{l}21418_{5 / 2}-80164_{3 / 2}^{\circ} \\
28720_{9 / 2}-87511_{7 / 2}^{\circ} \\
24788_{9 / 2}^{\circ}-83607_{11 / 2}^{\circ}\end{array}$ \\
\hline $\begin{array}{l}1743.377 \\
1742.574 \\
1742.073 \\
1741.563 \\
1740.471\end{array}$ & $\begin{array}{r}400 \\
2 \\
10 \\
1 \\
1\end{array}$ & $\begin{array}{l}57359.9 \\
57386.4 \\
57402.9 \\
57419.7 \\
57455.7\end{array}$ & $\begin{array}{l}32760_{13 / 2}-90119^{\circ}{ }_{11 / 2} \\
18211_{5 / 2}-75614^{\circ}{ }_{5 / 2}^{\circ} \\
14558_{9 / 2}-71978^{\circ}{ }_{7 / 2} \\
21238_{13 / 2}-78694_{11 / 2}^{\circ}\end{array}$ & $\begin{array}{l}1697.558 \\
1696.079 \\
1694.896 \\
1694.547 \\
1692.766\end{array}$ & $\begin{array}{r}3 \\
15 \\
1 \\
100 \\
30\end{array}$ & $\begin{array}{l}58908.1 \\
58959.5 \\
59000.7 \\
59012.8 \\
59074.9\end{array}$ & $\begin{array}{l}25409_{7 / 2}-84410^{\circ}{ }_{9 / 2} \\
25979_{15 / 2}-84992^{\circ}{ }_{15 / 2}\end{array}$ \\
\hline
\end{tabular}

${ }^{\text {a }}$ For doubly-classified lines, the wavelength is entered only once. 
TABLE X. Observed spectral lines of Pr III in the vacuum ultra violet region-Continued

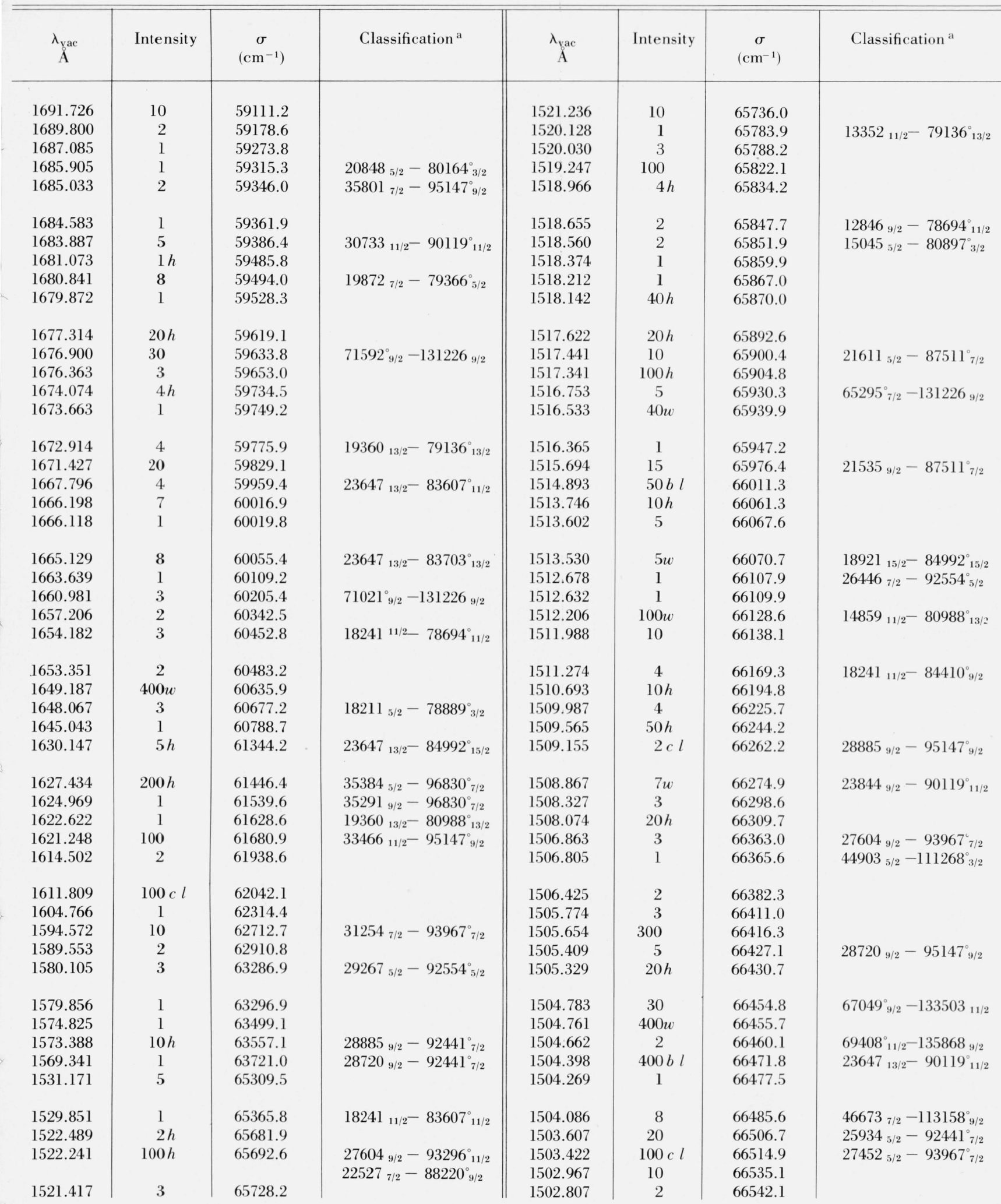


TABLE X. Observed spectral lines of $\operatorname{Pr}$ III in the vacuum ultra violet region-Continued

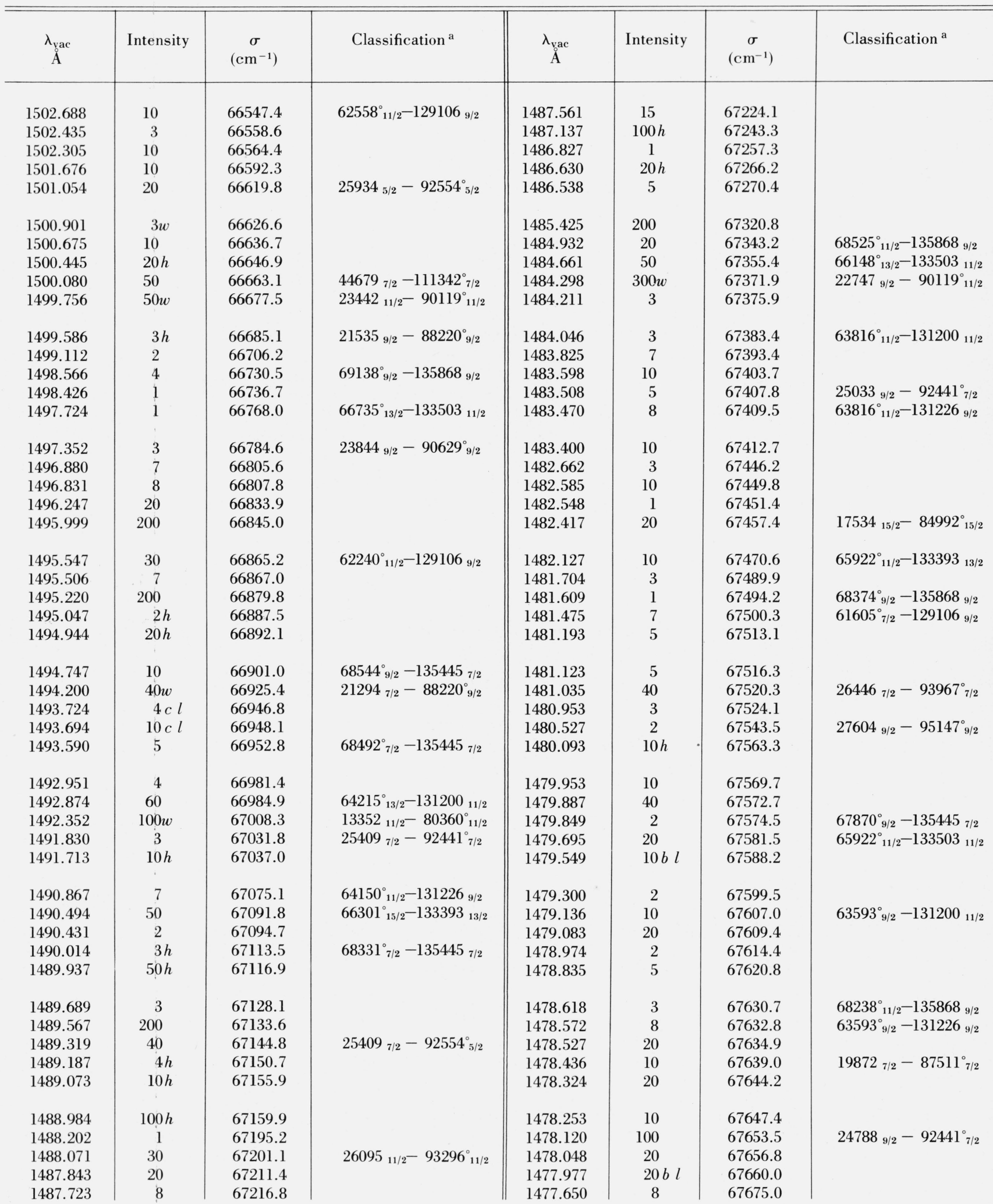

${ }^{a}$ For doubly-classified lines, the wavelength is entered only once. 
TABLE X. Observed spectral lines of Pr III in the vacuum ultra violet region-Continued

\begin{tabular}{|c|c|c|c|c|c|c|c|}
\hline$\lambda_{\mathrm{yac}}$ & Intensity & $\begin{array}{c}\sigma \\
\left(\mathrm{cm}^{-1}\right)\end{array}$ & Classification $^{a}$ & $\lambda_{\text {vac }}$ & Intensity & $\begin{array}{c}\sigma \\
\left(\mathrm{cm}^{-1}\right)\end{array}$ & Classification $^{a}$ \\
\hline 1477.559 & 6 & 67679.2 & & 1466.320 & 1 & 68197.9 & \\
\hline 1477.506 & 3 & 67681.6 & & 1466.011 & 1 & 68212.3 & \\
\hline 1477.109 & 15 & 67699.8 & & 1465.984 & 1 & 68213.6 & \\
\hline 1477.046 & 7 & 67702.7 & & 1465.899 & 2 & 68217.5 & \\
\hline 1476.843 & 30 & 67712.0 & $45844_{3 / 2}-113556_{5 / 2}^{\circ}$ & 1465.216 & 2 & 68249.3 & $15454_{13 / 2}-83703^{\circ}{ }_{13 / 2}$ \\
\hline 1476.566 & 2 & 67724.7 & & 1465.124 & 200 & 68253.6 & \\
\hline 1476.516 & 10 & 67727.0 & & 1465.021 & 200 & 68258.4 & \\
\hline 1476.274 & 200 & 67738.1 & & 1464.853 & 3 & 68266.2 & \\
\hline 1475.801 & 4 & 67759.8 & & 1464.742 & $5 b l$ & 68271.4 & \\
\hline 1475.700 & 10 & 67764.4 & & 1464.502 & $60 w$ & 68282.6 & \\
\hline 1475.562 & 10 & 67770.8 & & 1464.400 & 1 & 68287.3 & \\
\hline 1475.508 & $20 h$ & 67773.3 & & 1464.013 & 40 & 68305.4 & \\
\hline 1475.411 & 200 & 67777.7 & & 1463.825 & 100 & 68314.2 & \\
\hline 1474.094 & 50 & 67838.3 & & 1463.756 & 10 & 68317.4 & \\
\hline 1474.013 & 100 & 67842.0 & & 1463.554 & 400 & 68326.8 & \\
\hline 1473.818 & $200 w$ & 67851.0 & & 1463.332 & 200 & 68337.2 & \\
\hline 1473.720 & $4 h$ & 67855.5 & & 1463.233 & 400 & 68341.8 & \\
\hline 1473.364 & 2 & 67871.9 & & 1462.700 & 30 & 68366.7 & \\
\hline 1473.155 & 2 & 67881.5 & $22747_{9 / 2}-90629_{9 / 2}^{\circ}$ & 1462.585 & 20 & 68372.1 & \\
\hline 1472.995 & 1 & 67888.9 & & 1462.155 & 50 & 68392.2 & \\
\hline 1472.456 & 1 & 67913.7 & & 1462.019 & 1 & 68398.6 & \\
\hline 1472.332 & 20 & 67919.5 & & 1461.616 & $100 h$ & 68417.4 & \\
\hline 1472.142 & 1 & 67928.2 & & 1461.504 & 1 & 68422.7 & \\
\hline 1472.102 & 2 & 67930.1 & & 1461.405 & 4 & 68427.3 & \\
\hline 1471.895 & 3 & 67939.6 & & 1461.218 & 2 & 68436.0 & \\
\hline 1471.767 & 30 & 67945.5 & $28885_{9 / 2}-96830_{7 / 2}^{\circ}$ & 1460.632 & 2 & 68463.5 & \\
\hline 1471.518 & 3 & 67957.0 & & 1460.440 & 2 & 68472.5 & \\
\hline 1471.255 & 5 & 67969.2 & & 1460.223 & 1 & 68482.7 & \\
\hline 1470.908 & 3 & 67985.2 & & 1460.050 & 40 & 68490.8 & \\
\hline 1470.805 & 80 & 67990.0 & & 1459.674 & 40 & 68508.4 & $24788_{9 / 2}-93296_{11 / 2}^{\circ}$ \\
\hline 1470.324 & 10 & 68012.2 & & 1459.405 & 3 & 68521.1 & \\
\hline 1470.261 & $20 \mathrm{bl}$ & 68015.1 & & 1459.339 & 100 & 68524.2 & \\
\hline 1470.045 & $3 w$ & 68025.1 & & 1459.257 & $2 h$ & 68528.0 & $64865^{\circ}{ }_{11 / 2}-133393_{13 / 2}$ \\
\hline 1469.887 & 2 & 68032.4 & $25934_{5 / 2}-93967^{\circ}{ }_{7 / 2}$ & 1459.033 & 1 & 68538.5 & \\
\hline 1469.649 & 2 & 68043.4 & & 1458.771 & 8 & 68550.8 & \\
\hline 1469.511 & 7 & 68049.8 & $67395_{5 / 2}^{\circ}-135445_{7 / 2}$ & 1458.701 & 2 & 68554.1 & \\
\hline 1469.369 & 3 & 68056.4 & & 1458.614 & $30 h$ & 68558.2 & \\
\hline 1468.902 & 60 & 68078.1 & & 1458.202 & 10 & 68577.6 & \\
\hline 1468.779 & 10 & 68083.8 & $24470_{7 / 2}-92554_{5 / 2}^{\circ}$ & 1458.130 & 100 & 68581.0 & \\
\hline 1468.573 & $5 w$ & 68093.3 & $24461_{5 / 2}-92554_{5 / 2}^{\circ}$ & 1457.894 & 2 & 68592.1 & $66852^{\circ}{ }_{7 / 2}-135445_{7 / 2}$ \\
\hline 1468.399 & 200 & 68101.4 & $22527_{7 / 2}-90629_{9 / 2}^{\circ}$ & 1457.784 & 10 & 68597.3 & $23844_{9 / 2}-92441_{7 / 2}^{\circ}$ \\
\hline 1468.227 & 20 & 68109.3 & $28720_{9 / 2}-96830^{\circ}{ }_{7 / 2}$ & 1457.512 & 30 & 68610.1 & \\
\hline 1467.698 & $100 h$ & 68133.9 & & 1457.433 & $4 h$ & 68613.8 & \\
\hline 1467.646 & 3 & 68136.3 & & 1457.357 & $3 h$ & 68617.4 & \\
\hline 1467.595 & 10 & 68138.7 & & 1457.257 & 5 & 68622.1 & \\
\hline 1467.409 & 4 & 68147.3 & & 1456.949 & 40 & 68636.6 & \\
\hline 1467.247 & 3 & 68154.8 & & 1456.787 & 1 & 68644.2 & \\
\hline 1467.153 & 7 & 68159.2 & & 1456.738 & 1 & 68646.5 & $64857_{9 / 2}^{\circ}-133503_{11 / 2}$ \\
\hline 1467.081 & $10 h$ & 68162.6 & & 1456.574 & 2 & 68654.2 & \\
\hline 1466.971 & 2 & 68167.7 & & 1455.583 & 30 & 68701.0 & $26446_{7 / 2}-95147_{9 / 2}^{\circ}$ \\
\hline
\end{tabular}


TABLE X. Observed spectral lines of Pr III in the vacuum ultra violet region-Continued

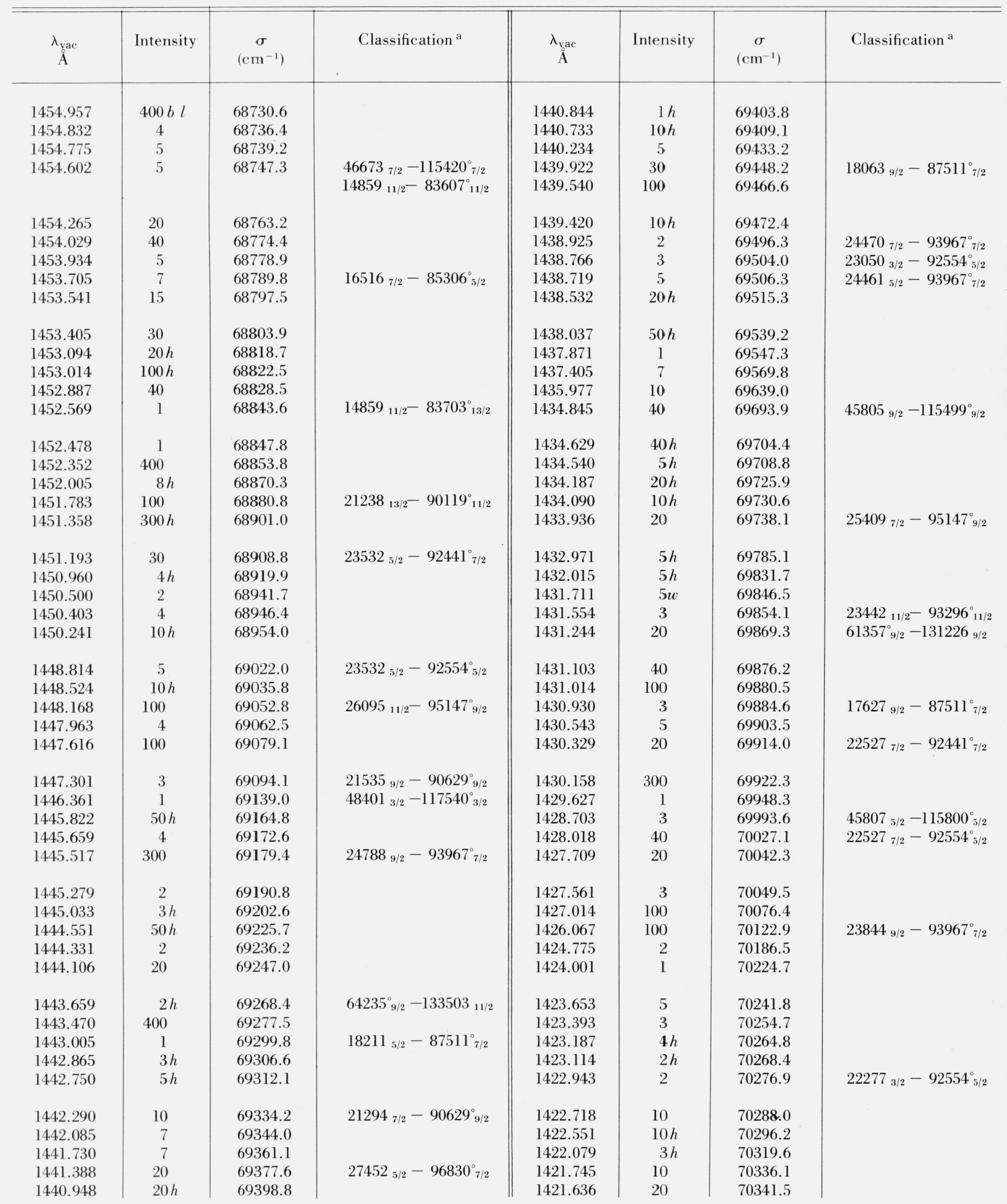


TABLE X. Observed spectral lines of $\operatorname{Pr}$ III in the vacuum ultra violet region - Continued

\begin{tabular}{|c|c|c|c|c|c|c|c|}
\hline$\underset{\substack{\text { yac } \\
\AA}}{\lambda^{\prime}}$ & Intensity & $\begin{array}{c}\sigma \\
\left(\mathrm{cm}^{-1}\right)\end{array}$ & Classification $^{\text {a }}$ & $\lambda_{\text {yac }}$ & Intensity & $\begin{array}{c}\sigma \\
\left(\mathrm{cm}^{-1}\right)\end{array}$ & Classification $^{\text {a }}$ \\
\hline 1421.479 & 1 & 70349.3 & & 1406.681 & 15 & 71089.3 & \\
\hline 1421.262 & 100 & 70360.0 & $24788_{9 / 2}-95147_{9 / 2}^{\circ}$ & 1406.071 & 15 & 71120.2 & $44679_{7 / 2}-115800_{5 / 2}^{\circ}$ \\
\hline 1420.795 & 15 & 70383.1 & $26446_{7 / 2}-96830^{\circ}{ }_{7 / 2}$ & 1405.544 & 50 & 71146.8 & $21294_{7 / 2}-92441_{7 / 2}^{\circ}$ \\
\hline 1420.334 & 5 & 70406.0 & & 1405.434 & 2 & 71152.4 & $62240^{\circ}{ }_{11 / 2}-133393_{13 / 2}$ \\
\hline 1420.071 & $50 h$ & 70419.0 & $19700_{11 / 2}-90119^{\circ}{ }_{11 / 2}$ & 1405.100 & 1 & 71169.3 & \\
\hline 1420.021 & $10 c l$ & 70421.5 & & 1404.974 & 30 & 71175.7 & \\
\hline 1418.966 & 7 & 70473.8 & $22080_{7 / 2}-92554_{5 / 2}^{\circ}$ & 1404.747 & 300 & 71187.2 & \\
\hline 1418.477 & 2 & 70498.1 & & 1404.102 & 20 & 71219.9 & $22747_{9 / 2}-93967_{7 / 2}^{\circ}$ \\
\hline 1417.458 & 1 & 70548.8 & $22747_{9 / 2}-93296_{11 / 2}^{\circ}$ & 1403.981 & 300 & 71226.0 & \\
\hline 1417.081 & 20 & 70567.6 & & 1403.868 & 4 & 71231.8 & \\
\hline 1416.779 & 20 & 70582.6 & & 1403.598 & 60 & 71245.5 & \\
\hline 1416.165 & 5 & 70613.2 & & 1403.310 & 100 & 71260.1 & $21294_{7 / 2}-92554_{5 / 2}^{\circ}$ \\
\hline 1415.874 & 1 & 70627.8 & $64817_{5 / 2}^{\circ}-135445_{7 / 2}$ & 1403.171 & 100 & 71267.2 & \\
\hline 1415.756 & 300 & 70633.6 & & 1402.907 & 40 & 71280.6 & \\
\hline 1414.393 & 3 & 70701.7 & & 1402.743 & 20 & 71288.9 & $40205_{3 / 2}-111494_{5 / 2}^{\circ}$ \\
\hline 1414.230 & 2 & 70709.8 & & 1402.599 & 3 & 71296.2 & \\
\hline 1414.137 & 50 & 70714.5 & $62678_{13 / 2}^{\circ}-133393_{13 / 2}$ & 1402.458 & 8 & 71303.4 & $23844_{9 / 2}-95147_{9 / 2}^{\circ}$ \\
\hline 1413.766 & 3 & 70733.1 & & 1402.122 & 8 & 71320.5 & $19308_{11 / 2}-90629_{9 / 2}^{\circ / 2}$ \\
\hline 1413.674 & 10 & 70737.7 & & 1402.047 & $100 \mathrm{cl}$ & 71324.3 & \\
\hline 1413.359 & 5 & 70753.4 & & 1402.030 & $30 \mathrm{cl}$ & 71325.2 & \\
\hline 1413.235 & $3 h$ & 70759.6 & $19360_{13 / 2}-90119_{11 / 2}^{\circ}$ & 1401.774 & 3 & 71338.2 & \\
\hline 1412.825 & 400 & 70780.2 & & 1401.405 & 4 & 71357.0 & \\
\hline 1412.655 & $5 h$ & 70788.7 & & 1401.176 & 100 & 71368.6 & \\
\hline 1412.492 & 3 & 70796.9 & & 1400.611 & $20 h$ & 71397.4 & \\
\hline 1412.297 & 20 & 70806.6 & $60419^{\circ}{ }_{11 / 2}-131226_{9 / 2}$ & 1400.434 & 7 & 71406.4 & $21148_{3 / 2}-92554_{5 / 2}^{\circ}$ \\
\hline 1412.087 & 10 & 70817.2 & & 1400.359 & $7 h$ & 71410.3 & \\
\hline 1411.924 & 20 & 70825.3 & $62678^{\circ}{ }_{13 / 2}-133503_{11 / 2}$ & 1400.160 & 3 & 71420.4 & $25409_{7 / 2}-96830_{7 / 2}^{\circ}$ \\
\hline 1411.819 & 20 & 70830.6 & $21611_{5 / 2}-92441_{7 / 2}^{\circ}$ & 1399.141 & 5 & 71472.4 & $39870_{9 / 2}-111342_{7 / 2}^{\circ}$ \\
\hline 1411.732 & $100 h$ & 70835.0 & & 1398.824 & 40 & 71488.6 & \\
\hline 1411.399 & $10 \mathrm{cl}$ & 70851.7 & & 1398.695 & 5 & 71495.2 & \\
\hline 1411.372 & $3 \mathrm{cl}$ & 70853.0 & & 1398.619 & 40 & 71499.1 & \\
\hline 1411.184 & 2 & 70862.5 & & 1397.919 & 2 & 71534.9 & \\
\hline 1410.745 & 10 & 70884.5 & $50647_{11 / 2}-121532^{\circ}{ }_{11 / 2}$ & 1397.770 & 4 & 71542.5 & \\
\hline 1410.651 & 100 & 70889.3 & $64979^{\circ}{ }_{7 / 2}-135868_{9 / 2}$ & 1397.421 & $100 h$ & 71560.4 & \\
\hline 1410.528 & $10 \mathrm{bl}$ & 70895.4 & $25934_{5 / 2}-96830^{\circ}{ }_{7 / 2}$ & 1397.344 & 20 & 71564.3 & \\
\hline 1410.304 & 60 & 70906.7 & $21535_{9 / 2}-92441_{7 / 2}^{\circ}$ & 1397.227 & 5 & 71570.3 & \\
\hline 1409.801 & $100 h$ & 70932.0 & $58174_{9 / 2}^{\circ}-129106_{9 / 2}$ & 1396.842 & 7 & 71590.0 & \\
\hline 1409.708 & 5 & 70936.7 & & 1396.444 & 50 & 71610.5 & \\
\hline 1409.535 & 3 & 70945.4 & $62558^{\circ}{ }_{11 / 2}-133503_{11 / 2}$ & 1396.219 & 20 & 71622.0 & \\
\hline 1409.479 & 20 & 70948.2 & $58158_{7 / 2}^{\circ}-129106_{9 / 2}$ & 1395.722 & 2 & 71647.5 & \\
\hline 1408.544 & 3 & 70995.3 & $16516_{7 / 2}-87511_{7 / 2}^{\circ}$ & 1395.658 & 5 & 71650.8 & \\
\hline 1408.221 & 10 & 71011.6 & $64857_{9 / 2}^{\circ}-135868_{9 / 2}$ & 1395.383 & 8 & 71664.9 & \\
\hline 1407.904 & 2 & 71027.6 & & 1395.316 & 3 & 71668.4 & \\
\hline 1407.773 & 20 & 71034.2 & $60166_{9 / 2}^{\circ}-131200_{11 / 2}$ & 1395.196 & $4 h$ & 71674.5 & \\
\hline 1407.574 & 3 & 71044.2 & $64401_{5 / 2}^{\circ}-135445_{7 / 2}$ & 1394.784 & 10 & 71695.7 & $45844_{3 / 2}-117540_{3 / 2}^{\circ}$ \\
\hline 1407.485 & $30 h$ & 71048.7 & & 1394.718 & $20 h$ & 71699.1 & \\
\hline 1407.352 & 6 & 71055.4 & & 1394.585 & 60 & 71705.9 & $20848_{5 / 2}-92554_{5 / 2}^{\circ}$ \\
\hline 1407.283 & $10 c l$ & 71058.9 & $13352_{11 / 2}-84410_{9 / 2}^{\circ}$ & & & & $23442_{11 / 2}-95147_{9 / 2}^{\circ}$ \\
\hline 1407.260 & $10 \mathrm{cl}$ & 71060.1 & $60166_{9 / 2}^{\circ}-131226_{9 / 2}$ & 1394.540 & 2 & 71708.2 & \\
\hline 1407.212 & 5 & 71062.5 & $40205_{3 / 2}-111268_{3 / 2}^{\circ}$ & 1394.435 & 3 & 71713.6 & \\
\hline
\end{tabular}


TABLE X. Observed spectral lines of Pr III in the vacuum ultra violet region-Continued

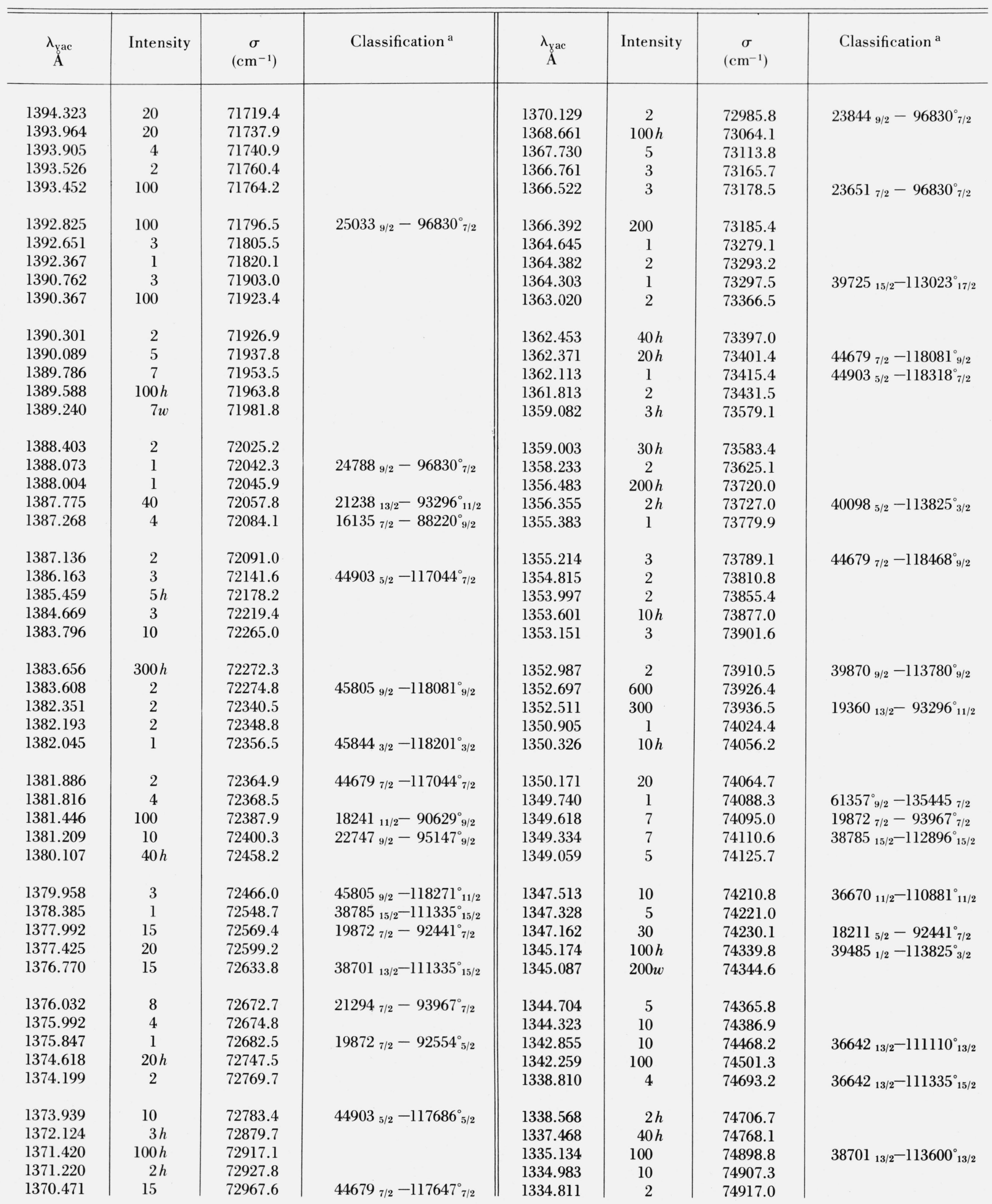


TABLE X. Observed spectral lines of $\mathrm{Pr}$ III in the vacuum ultra violet region-Continued

\begin{tabular}{|c|c|c|c|c|c|c|c|}
\hline$\lambda_{\text {vac }}$ & Intensity & $\begin{array}{c}\sigma \\
\left(\mathrm{cm}^{-1}\right)\end{array}$ & Classification $^{\text {a }}$ & $\lambda_{\mathrm{Vac}}$ & Intensity & $\begin{array}{c}\sigma \\
\left(\mathrm{cm}^{-1}\right)\end{array}$ & Classification $^{\text {a }}$ \\
\hline 1333.802 & $20 h$ & 74973.6 & & 1294.456 & 2 & 77252.5 & \\
\hline 1332.359 & 1 & 75054.8 & $18241_{11 / 2}-93296_{11 / 2}^{\circ}$ & 1294.103 & 3 & 77273.6 & $36640_{7 / 2}-113914_{5 / 2}^{\circ}$ \\
\hline 1331.490 & 1 & 75103.8 & $15525_{11 / 2}-90629_{9 / 2}^{\circ}$ & 1294.043 & 10 & 77277.2 & $13352_{11 / 2}-90629_{9 / 2}^{\circ}$ \\
\hline 1330.985 & 60 & 75132.3 & $38701_{13 / 2}-113833_{15 / 2}^{\circ}$ & 1293.079 & 5 & 77334.8 & $40205_{3 / 2}-117540_{3 / 2}^{\circ}$ \\
\hline 1329.459 & 1 & 75218.6 & & 1292.456 & $3 h$ & 77372.1 & \\
\hline 1328.452 & 30 & 75275.6 & $38549_{1 / 2}-113825_{3 / 2}^{\circ}$ & 1292.062 & 1 & 77395.7 & $15045_{5 / 2}-92441_{7 / 2}^{\circ}$ \\
\hline 1328.207 & 5 & 75289.5 & $45805_{9 / 2}-121095^{\circ}{ }_{11 / 2}$ & 1291.104 & 20 & 77453.1 & $38785_{15 / 2}-116238^{\circ}{ }_{15 / 2}$ \\
\hline 1325.155 & 4 & 75462.9 & $41026_{17 / 2}-116489^{\circ}{ }_{17 / 2}$ & & & & $39870_{9 / 2}-117323^{\circ}{ }_{11 / 2}$ \\
\hline 1324.595 & $50 h$ & 75494.8 & & 1289.817 & 1 & 77530.4 & \\
\hline 1322.376 & 1 & 75621.4 & & 1288.999 & 2 & 77579.6 & $37919_{7 / 2}-115499_{9 / 2}^{\circ}$ \\
\hline 1321.520 & 5 & 75670.4 & $39732_{11 / 2}-115403^{\circ}{ }_{11 / 2}$ & 1287.736 & $2 h$ & 77655.7 & \\
\hline 1319.844 & 1 & 75766.5 & $39732_{11 / 2}-115499_{9 / 2}^{\circ}$ & 1286.935 & 300 & 77704.0 & $38785_{15 / 2}-116489^{\circ}{ }_{17 / 2}$ \\
\hline 1319.796 & 1 & 75769.3 & $14859_{11 / 2}-90629_{9 / 2}^{\circ}$ & 1286.530 & $40 h$ & 77728.5 & \\
\hline 1316.719 & 3 & 75946.4 & $39725_{15 / 2}-115672^{\circ}{ }_{15 / 2}$ & 1286.233 & 1 & 77746.4 & \\
\hline 1316.264 & 1 & 75972.6 & $36670_{11 / 2}-112643^{\circ}{ }_{11 / 2}$ & 1284.023 & 10 & 77880.2 & $37919_{7 / 2}-115800_{5 / 2}^{\circ}$ \\
\hline 1315.596 & 1 & 76011.2 & $38785_{15 / 2}-114797^{\circ}{ }_{13 / 2}$ & 1278.394 & $3 h$ & 78223.1 & \\
\hline 1314.573 & 2 & 76070.3 & $14558_{9 / 2}-90629_{9 / 2}^{\circ}$ & 1277.726 & 2 & 78264.0 & \\
\hline 1314.136 & 20 & 76095.6 & $38701_{13 / 2}-114797^{\circ}{ }_{13 / 2}$ & 1277.553 & $50 h$ & 78274.6 & \\
\hline 1313.582 & 10 & 76127.7 & $36642_{13 / 2}-112769^{\circ}{ }_{13 / 2}$ & 1277.286 & 30 & 78291.0 & \\
\hline 1313.538 & 2 & 76130.3 & $35137_{3 / 2}-111268_{3 / 2}^{\circ}$ & 1276.937 & 1 & 78312.4 & \\
\hline 1313.376 & $5 h$ & 76139.6 & & 1276.817 & $2 h$ & 78319.8 & \\
\hline 1312.336 & 7 & 76199.0 & $39732_{11 / 2}-115933_{11 / 2}^{\circ}$ & 1276.612 & $2 h$ & 78332.3 & \\
\hline 1310.972 & $1 h$ & 76279.3 & $37011_{5 / 2}-113291^{\circ}{ }_{7 / 2}$ & 1276.327 & 1 & 78349.8 & $38694_{5 / 2}-117044_{7 / 2}^{\circ}$ \\
\hline 1310.898 & $2 h$ & 76283.6 & & 1275.701 & 1 & 78388.3 & \\
\hline 1310.307 & 2 & 76318.0 & $35024_{7 / 2}-111342_{7 / 2}^{\circ}$ & 1274.924 & 20 & 78436.0 & \\
\hline 1310.001 & 1 & 76335.8 & & 1273.361 & 5 & 78532.3 & $35024_{7 / 2}-113556_{5 / 2}^{\circ}$ \\
\hline 1309.831 & $2 h$ & 76345.7 & & 1272.901 & 20 & 78560.7 & $25244_{15 / 2}^{\circ}-103805_{13 / 2}$ \\
\hline 1308.577 & 2 & 76418.9 & $16135_{7 / 2}-92554_{5 / 2}^{\circ}$ & 1272.820 & 1 & 78565.7 & $39120_{3 / 2}-117686_{5 / 2}^{\circ}$ \\
\hline 1308.234 & 2 & 76438.9 & $39870_{9 / 2}-116309^{\circ}{ }_{11 / 2}$ & 1272.690 & 3 & 78573.7 & $23091^{\circ}{ }_{3 / 2}^{\circ}-101665_{5 / 2}$ \\
\hline 1307.215 & $20 h$ & 76498.5 & & 1271.934 & $10 h$ & 78620.4 & \\
\hline 1306.420 & 1 & 76545.1 & $37011_{5 / 2}-113556_{5 / 2}^{\circ}$ & 1271.829 & 1 & 78626.9 & \\
\hline 1305.892 & 1 & 76576.0 & $39732_{11 / 2}-116309^{\circ}{ }_{11 / 2}$ & 1269.499 & 1 & 78771.2 & $34520_{5 / 2}-113291^{\circ}{ }_{7 / 2}$ \\
\hline 1305.771 & 1 & 76583.1 & $39870_{9 / 2}-116453_{9 / 2}^{\circ}$ & 1269.345 & 1 & 78780.8 & $36640_{7 / 2}-115420_{7 / 2}^{\circ}$ \\
\hline 1305.623 & 1 & 76591.8 & & 1269.232 & 2 & 78787.8 & $37011_{5 / 2}-115800_{5 / 2}^{\circ}$ \\
\hline 1303.501 & 2 & 76716.5 & $37197_{3 / 2}-113914_{5 / 2}^{\circ}$ & 1268.819 & 2 & 78813.4 & \\
\hline 1302.961 & 3 & 76748.3 & $34520_{5 / 2}-111268_{3 / 2}^{\circ}$ & 1268.084 & 1 & 78859.1 & $36640_{7 / 2}-115499_{9 / 2}^{\circ}$ \\
\hline 1302.884 & $3 h$ & 76752.8 & & 1267.783 & 40 & 78877.8 & $39732_{11 / 2}-118610_{13 / 2}^{\circ}$ \\
\hline 1302.696 & 10 & 76763.9 & $39725_{15 / 2}-116489^{\circ}{ }_{17 / 2}$ & 1267.235 & $2 h$ & 78912.0 & \\
\hline 1300.617 & 50 & 76886.6 & $38785_{15 / 2}-115672^{\circ}{ }_{15 / 2}$ & 1266.730 & $2 h$ & 78943.4 & \\
\hline 1300.285 & 3 & 76906.2 & $18241_{11 / 2}-95147_{9 / 2}^{\circ}$ & 1265.676 & 20 & 79009.2 & $39870_{9 / 2}-118879^{\circ}{ }_{11 / 2}$ \\
\hline 1299.811 & $30 h$ & 76934.3 & & 1265.347 & 5 & 79029.7 & $36640_{7 / 2}-115670_{7 / 2}^{\circ}$ \\
\hline 1299.407 & 10 & 76958.2 & $36642_{13 / 2}-113600^{\circ}{ }_{13 / 2}$ & & & & $36642_{13 / 2}-115672^{\circ}{ }_{15 / 2}$ \\
\hline 1299.193 & 2 & 76970.9 & $38701_{13 / 2}-115672_{15 / 2}^{\circ}$ & 1264.221 & 10 & 79100.1 & \\
\hline 1298.693 & 40 & 77000.5 & & 1263.489 & 20 & 79145.9 & $39732_{11 / 2}-118879^{\circ}{ }_{11 / 2}$ \\
\hline 1298.630 & 100 & 77004.2 & & 1263.274 & 20 & 79159.4 & $36640_{7 / 2}-115800_{5 / 2}^{\circ}$ \\
\hline 1298.410 & 2 & 77017.3 & & 1263.160 & 1 & 79166.5 & \\
\hline 1298.139 & $10 h$ & 77033.4 & & 1261.871 & 20 & 79247.4 & $39024_{9 / 2}-118271_{11 / 2}^{\circ}$ \\
\hline 1297.828 & 3 & 77051.8 & $384488_{9 / 2}-115499_{9 / 2}^{\circ}$ & 1260.991 & 20 & 79302.7 & \\
\hline 1295.473 & 30 & 77191.9 & $36642_{13 / 2}-113833_{15 / 2}^{\circ}$ & 1259.747 & 4 & 79381.0 & $36640_{7 / 2}-116021^{\circ}{ }_{7 / 2}$ \\
\hline 1294.860 & 2 & 77228.4 & & 1258.859 & $4 h$ & 79437.0 & \\
\hline
\end{tabular}


TABLE X. Observed spectral lines of Pr III in the vacuum ultra violet region-Continued

\begin{tabular}{|c|c|c|c|c|c|c|c|}
\hline$\underset{\AA}{\lambda_{\mathrm{vac}}}$ & Intensity & $\begin{array}{c}\sigma \\
\left(\mathrm{cm}^{-1}\right)\end{array}$ & Classification $^{\text {a }}$ & $\underset{\AA}{\lambda_{\mathrm{yac}}}$ & Intensity & $\begin{array}{c}\sigma \\
\left(\mathrm{cm}^{-1}\right)\end{array}$ & Classification $^{\text {a }}$ \\
\hline 1258.754 & 1 & 79443.6 & & 1217.644 & 40 & 82125.8 & \\
\hline 1258.700 & 2 & 79447.0 & $24357^{\circ}{ }_{11 / 2}-103805_{13 / 2}$ & 1217.473 & 3 & 82137.3 & $30505_{11 / 2}-112643_{11 / 2}^{\circ}$ \\
\hline 1257.936 & 1 & 79495.3 & $35828_{9 / 2}-115324_{9 / 2}^{\circ}$ & 1217.169 & 4 & 82157.9 & $29835_{9 / 2}-111993_{9 / 2}^{\circ}$ \\
\hline 1257.835 & $10 h$ & 79501.7 & & 1217.063 & 1 & 82165.0 & \\
\hline 1256.362 & 20 & 79594.9 & $12846_{9 / 2}-92441_{7 / 2}^{\circ}$ & 1215.996 & 2 & 82237.1 & $36642_{13 / 2}-118879^{\circ}{ }_{11 / 2}$ \\
\hline 1255.468 & 1 & 79651.6 & $38549_{1 / 2}-118201_{3 / 2}^{\circ}$ & 1214.562 & 1 & 82334.2 & \\
\hline 1255.162 & 3 & 79671.0 & $35828_{9 / 2}-115499_{9 / 2}^{\circ}$ & 1212.271 & 1 & 82489.8 & $35828_{9 / 2}-118318_{7 / 2}^{\circ}$ \\
\hline 1254.915 & 5 & 79686.7 & & 1212.053 & 2 & 82504.6 & \\
\hline 1252.937 & 7 & 79812.5 & $36640_{7 / 2}-116453_{9 / 2}^{\circ}$ & 1211.998 & 1 & 82508.4 & $39024_{9 / 2}-121532^{\circ}{ }_{11 / 2}$ \\
\hline & & & $48401_{3 / 2}-128214_{3 / 2}^{\circ}$ & 1211.894 & 60 & 82515.5 & \\
\hline 1250.337 & 20 & 79978.4 & & 1211.111 & 3 & 82568.8 & \\
\hline 1250.190 & 10 & 79987.8 & & 1210.532 & 3 & 82608.3 & \\
\hline 1249.025 & 3 & 80062.4 & $23245_{5 / 2}^{\circ}-103308_{7 / 2}$ & 1210.158 & 4 & 82633.8 & \\
\hline 1246.860 & $5 h$ & 80201.5 & & 1210.078 & 20 & 82639.3 & \\
\hline 1245.521 & 5 & 80287.7 & $14859_{11 / 2}-95147_{9 / 2}^{\circ}$ & 1209.191 & 2 & 82699.9 & \\
\hline 1244.669 & 2 & 80342.6 & $37197_{3 / 2}-117540_{3 / 2}^{\circ}$ & 1208.938 & $2 h$ & 82717.2 & \\
\hline 1242.667 & 1 & 80472.1 & & 1208.755 & 2 & 82729.8 & $27604_{9 / 2}-110333_{7 / 2}^{\circ}$ \\
\hline 1241.027 & $5 h$ & 80578.4 & & & & & $38701_{13 / 2}-121431_{13 / 2}^{\circ}$ \\
\hline 1239.467 & 7 & 80679.8 & $24886_{7 / 2}^{\circ}-105566_{9 / 2}$ & 1208.272 & 2 & 82762.8 & $45805_{9 / 2}-128568_{9 / 2}^{\circ}$ \\
\hline 1238.007 & 4 & 80775.0 & $35024_{7 / 2}-115800_{5 / 2}^{\circ}$ & 1208.013 & $40 b l$ & 82780.6 & \\
\hline 1237.976 & 2 & 80777.0 & & 1205.675 & $2 h$ & 82941.1 & \\
\hline 1236.596 & 1 & 80867.2 & & 1205.511 & $20 h$ & 82952.4 & \\
\hline 1235.607 & $20 h$ & 80931.9 & & 1204.999 & $20 \mathrm{bl}$ & 82987.6 & \\
\hline 1235.369 & 1 & 80947.5 & & 1204.511 & $4 h$ & 83021.2 & \\
\hline 1234.649 & 1 & 80994.7 & $36652_{5 / 2}-117647^{\circ}{ }_{7 / 2}$ & 1204.078 & 50 & 83051.1 & $35828_{9 / 2}-118879^{\circ}{ }_{11 / 2}$ \\
\hline 1234.534 & 3 & 81002.2 & & 1204.000 & 4 & 83056.5 & $35024_{7 / 2}-118081_{9 / 2}^{\circ}$ \\
\hline 1234.351 & 1 & 81014.2 & & 1203.946 & $2 h$ & 83060.2 & \\
\hline 1234.150 & 3 & 81027.4 & & 1203.448 & 2 & 83094.6 & $30505_{11 / 2}-113600^{\circ}{ }_{13 / 2}$ \\
\hline 1233.869 & 3 & 81045.9 & $29835_{9 / 2}-110881_{11 / 2}^{\circ}$ & 1203.266 & 1 & 83107.1 & \\
\hline & & & $36640_{7 / 2}-117686_{5 / 2}^{\circ}$ & 1203.106 & $10 h$ & 83118.2 & \\
\hline 1233.573 & 1 & 81065.3 & $29267_{5 / 2}-110333_{7 / 2}^{\circ}$ & 1203.054 & $2 h$ & 83121.8 & \\
\hline 1233.242 & 1 & 81087.1 & $29835_{9 / 2}-110922_{9 / 2}^{\circ}$ & 1202.997 & 1 & 83125.7 & \\
\hline 1231.958 & 1 & 81171.6 & & 1202.889 & 1 & 83133.2 & \\
\hline 1229.989 & $3 h$ & 81301.5 & & 1202.515 & 2 & 83159.0 & \\
\hline 1229.728 & 20 & 81318.8 & & 1202.463 & $5 b l$ & 83162.6 & \\
\hline 1228.610 & $10 \mathrm{cl}$ & 81392.8 & $39725_{15 / 2}-121119^{\circ}{ }_{15 / 2}$ & 1202.389 & 4 & 83167.8 & $25391^{\circ}{ }_{13 / 2}-108559_{11 / 2}$ \\
\hline 1228.067 & 2 & 81428.8 & $35024_{7 / 2}-116453_{9 / 2}^{\circ}$ & 1201.999 & 1 & 83194.8 & $27138_{7 / 2}-110333_{7 / 2}^{\circ}$ \\
\hline 1224.015 & 5 & 81698.3 & $39732_{11 / 2}-121431^{\circ}{ }_{13 / 2}$ & 1200.879 & 1 & 83272.3 & $28720_{9 / 2}-111993_{9 / 2}^{\circ}$ \\
\hline 1223.251 & 1 & 81749.4 & & 1200.565 & 3 & 83294.1 & $35024_{7 / 2}-118318^{\circ}$ \\
\hline 1223.055 & 1 & 81762.5 & & 1200.254 & 5 & 83315.7 & \\
\hline 1222.497 & 10 & 81799.8 & $39732_{11 / 2}-121532^{\circ}{ }_{11 / 2}$ & 1200.203 & $5 b l$ & 83319.2 & \\
\hline 1222.214 & 2 & 81818.7 & $35828_{9 / 2}-117647_{7 / 2}^{\circ}$ & 1200.140 & 8 & 83323.6 & $29835_{9 / 2}-113158_{9 / 2}^{\circ}$ \\
\hline 1222.173 & 1 & 81821.5 & & 1200.067 & $5 h$ & 83328.7 & \\
\hline 1220.398 & 1 & 81940.5 & $36670_{11 / 2}-118610^{\circ}{ }_{13 / 2}$ & 1198.482 & $2 h$ & 83438.9 & \\
\hline 1220.279 & 4 & 81948.5 & & 1198.399 & 40 & 83444.7 & $35024_{7 / 2}-118468_{9 / 2}^{\circ}$ \\
\hline 1219.975 & 2 & 81968.9 & $36642_{13 / 2}-118610^{\circ}{ }_{13 / 2}$ & 1197.869 & 3 & 83481.6 & \\
\hline 1219.500 & 1 & 82000.8 & $29267_{5 / 2}-111268_{3 / 2}^{\circ}$ & 1197.651 & 2 & 83496.8 & \\
\hline 1219.208 & 20 & 82020.5 & $35024_{7 / 2}-117044^{\circ}{ }_{7 / 2}$ & 1197.589 & 50 & 83501.1 & $27380_{11 / 2}-110881_{11 / 2}^{\circ}$ \\
\hline 1218.533 & 2 & 82065.9 & & 1197.505 & 30 & 83507.0 & $29263_{13 / 2}-112769^{\circ}{ }_{13 / 2}$ \\
\hline 1218.403 & 4 & 82074.6 & $29267_{5 / 2}-111342^{\circ}{ }_{7 / 2}$ & 1196.999 & 1 & 83542.3 & $27380_{11 / 2}-110922_{9 / 2}^{\circ}$ \\
\hline
\end{tabular}


TABLE X. Observed spectral lines of Pr III in the vacuum ultra violet region - Continued

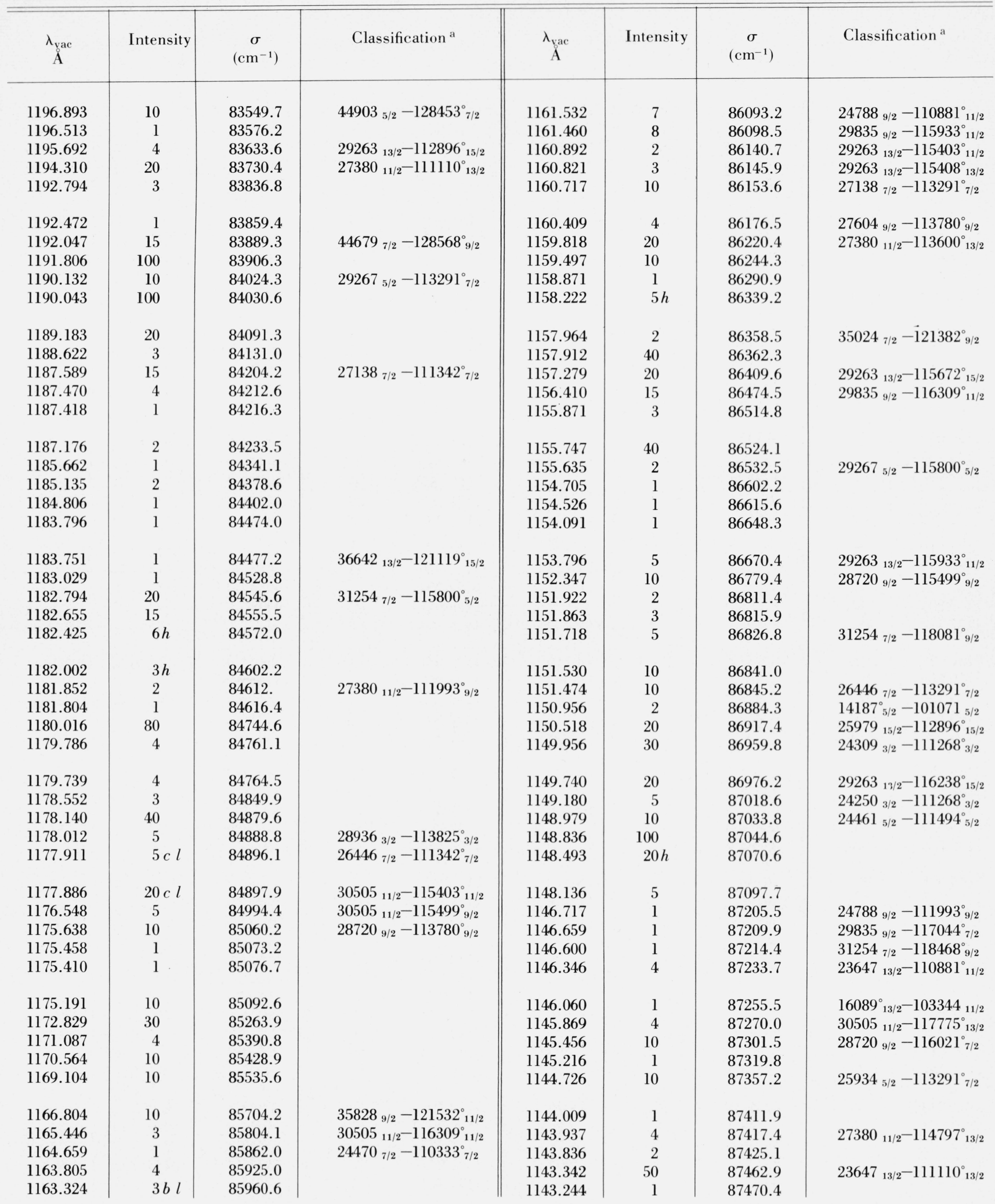


TABLE X. Observed spectral lines of Pr III in the vacuum ultra violet region-Continued

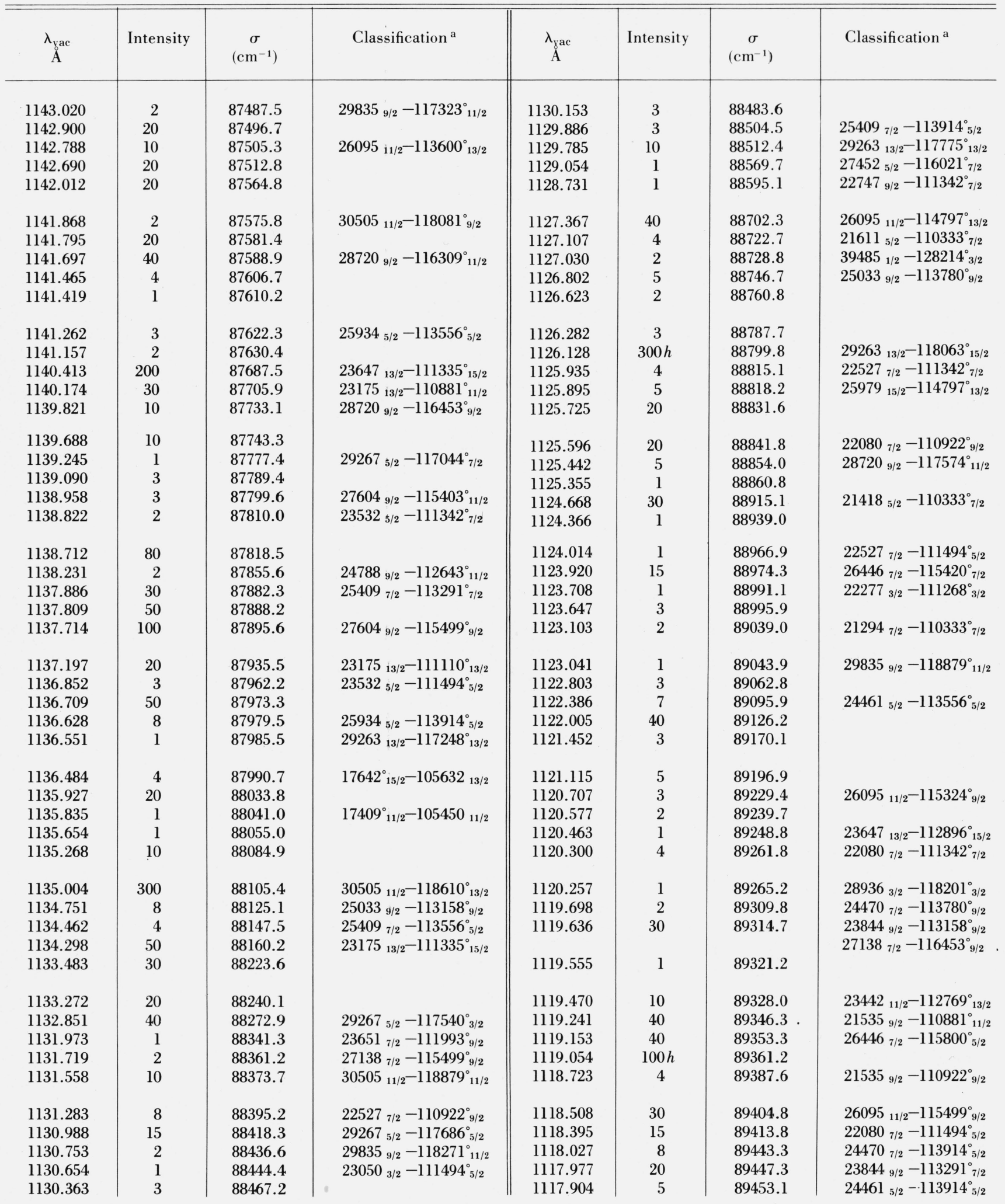


TABLE X. Observed spectral lines of Pr III in the vacuum ultra violet region-Continued

\begin{tabular}{|c|c|c|c|c|c|c|c|}
\hline$\lambda_{\text {yac }}$ & Intensity & $\begin{array}{c}\sigma \\
\left(\mathrm{cm}^{-1}\right)\end{array}$ & Classification $^{\text {a }}$ & $\lambda_{\mathrm{vac}}$ & Intensity & $\begin{array}{c}\sigma \\
\left(\mathrm{cm}^{-1}\right)\end{array}$ & Classification $^{a}$ \\
\hline 1117.803 & 10 & 89461.2 & & 1107.998 & 40 & 90252.9 & \\
\hline 1117.500 & 6 & 89485.5 & $\begin{array}{l}20848_{5 / 2}-110333_{7 / 2}^{\circ} \\
25934_{5 / 2}-115420^{\circ}{ }_{7 / 2}\end{array}$ & 1107.911 & 80 & 90260.0 & $\begin{array}{l}25979_{15 / 2}-116238^{\circ}{ }_{15 / 2} \\
25409_{7 / 2}-115670^{\circ}{ }_{7 / 2}\end{array}$ \\
\hline 1117.230 & 3 & 89507.1 & $23651_{7 / 2}-113158_{9 / 2}^{\circ}$ & 1107.881 & $20 c l$ & 90262.4 & $23651_{7 / 2}-113914_{5 / 2}^{\circ}$ \\
\hline 1116.681 & 30 & 89551.1 & $28720_{9 / 2}-118271_{11 / 2}^{\circ}$ & 1107.536 & 100 & 90290.5 & $25033_{9 / 2}-115324_{9 / 2}^{\circ}$ \\
\hline 1116.516 & 3 & 89564.3 & & 1107.096 & 20 & 90326.4 & \\
\hline 1116.382 & 30 & 89575.1 & $\begin{array}{l}24250_{3 / 2}-113825^{\circ} \\
26446_{7 / 2}-116021^{\circ}\end{array}$ & $\begin{array}{l}1106.948 \\
1106.755\end{array}$ & $\begin{array}{l}2 \\
3\end{array}$ & $\begin{array}{l}90338.5 \\
90354.2\end{array}$ & $23442_{11 / 2}-113780_{9 / 2}^{\circ}$ \\
\hline 1116.264 & 3 & 89584.5 & & 1106.567 & 80 & 90369.6 & $25033_{9 / 2}-115403_{11 / 2}^{\circ}$ \\
\hline 1116.139 & 50 & 89594.6 & $23175_{13 / 2}-112769^{\circ}{ }_{13 / 2}$ & 1106.423 & 20 & 90381.4 & $23532_{5 / 2}-113914_{5 / 2}^{\circ}$ \\
\hline 1115.725 & 15 & 89627.8 & $21294_{7 / 2}-110922_{9 / 2}^{\circ}$ & 1106.341 & $10 c l$ & 90388.0 & \\
\hline 1115.571 & 30 & 89640.2 & $23651_{7 / 2}-113291^{\circ}{ }_{7 / 2}$ & 1106.311 & 30 & 90390.5 & $25409_{7 / 2}-115800_{5 / 2}^{\circ}$ \\
\hline 1115.429 & 10 & 89651.6 & & 1106.252 & 3 & 90395.3 & $27380_{11 / 2}-117775^{\circ}{ }_{13 / 2}$ \\
\hline 1115.353 & 1 & 89657.7 & $21611_{5 / 2}-111268_{3 / 2}^{\circ}$ & 1106.060 & 4 & 90411.0 & $22747_{9 / 2}-113158_{9 / 2}^{\circ}$ \\
\hline 1114.912 & 60 & 89693.2 & $25979_{15 / 2}-115672^{\circ}{ }_{15 / 2}$ & 1105.962 & 200 & 90419.0 & \\
\hline 1114.581 & 30 & 89719.8 & & 1105.754 & 6 & 90436.0 & \\
\hline 1114.436 & 1 & 89731.5 & $21611_{5 / 2}-111342^{\circ}{ }_{7 / 2}$ & 1105.492 & 2 & 90457.5 & $21535_{9 / 2}-111993_{9 / 2}^{\circ}$ \\
\hline 1114.228 & 20 & 89748.2 & $28720_{9 / 2}-118468_{9 / 2}^{\circ}$ & 1105.386 & 80 & 90466.1 & $25033_{9 / 2}-115499_{9 / 2}^{\circ}$ \\
\hline 1113.753 & 10 & 89786.5 & $23844_{9 / 2}-113630_{7 / 2}^{\circ}$ & 1105.214 & 20 & 90480.2 & \\
\hline 1113.489 & 10 & 89807.8 & $21535_{9 / 2}-111342_{7 / 2}^{\circ}$ & 1104.843 & 2000 & 90510.6 & $25979_{15 / 2}-116489^{\circ}{ }_{17 / 2}$ \\
\hline 1112.965 & 10 & 89850.1 & $21418_{5 / 2}-111268^{\circ}{ }_{3 / 2}$ & 1104.721 & 10 & 90520.6 & \\
\hline 1112.582 & 10 & 89881.0 & & 1104.525 & 40 & 90536.7 & $24788_{9 / 2}-115324_{9 / 2}^{\circ}$ \\
\hline 1112.549 & 5 & 89883.7 & $21611_{5 / 2}-111494_{5 / 2}^{\circ}$ & 1104.389 & 4 & 90547.8 & $27138_{7 / 2}-117686_{5 / 2}^{\circ}$ \\
\hline 1112.400 & 1 & 89895.7 & $22747_{9 / 2}-112643_{11 / 2}^{\circ}$ & 1104.173 & 2 & 90565.5 & $20315_{9 / 2}-110881_{11 / 2}^{\circ}$ \\
\hline 1112.268 & 30 & 89906.4 & $27138_{7 / 2}-117044_{7 / 2}^{\circ}$ & 1103.780 & 20 & 90597.8 & $26446_{7 / 2}-117044^{\circ}{ }_{7 / 2}$ \\
\hline 1112.162 & 10 & 89915.0 & $25409_{7 / 2}-115324_{9 / 2}^{\circ}$ & 1103.660 & 40 & 90607.6 & \\
\hline 1112.050 & 5 & 89924.0 & $21418_{5 / 2}-111342^{\circ}{ }_{7 / 2}$ & 1103.605 & 10 & 90612.1 & $25409_{7 / 2}-116021^{\circ}{ }_{7 / 2}$ \\
\hline 1111.902 & 10 & 89936.0 & $23844_{9 / 2}-113780_{9 / 2}^{\circ}$ & 1103.553 & $20 h$ & 90616.4 & \\
\hline 1111.768 & 40 & 89946.8 & & 1103.354 & 5 & 90632.7 & $24788_{9 / 2}-115420_{7 / 2}^{\circ}$ \\
\hline 1111.694 & 100 & 89952.8 & $23647_{13 / 2}-113600^{\circ}{ }_{13 / 2}$ & 1103.185 & 8 & 90646.6 & $20848_{5 / 2}-111494_{5 / 2}^{\circ}$ \\
\hline 1111.539 & 20 & 89965.4 & & 1103.150 & 15 & 90649.5 & $37919_{7 / 2}-128568_{9 / 2}^{\circ}$ \\
\hline 1111.475 & 10 & 89970.5 & $27604_{9 / 2}-117574_{11 / 2}^{\circ}$ & 1103.035 & 400 & 90659.0 & $23175_{13 / 2}-113833_{15 / 2}^{\circ}$ \\
\hline 1111.373 & 3 & 89978.8 & $23651_{7 / 2}-113630_{7 / 2}^{\circ}$ & 1102.938 & 1 & 90666.9 & $27604_{9 / 2}-118271_{11 / 2}^{\circ}$ \\
\hline 1111.174 & 50 & 89994.9 & $28885_{9 / 2}-118879^{\circ}{ }_{11 / 2}$ & 1102.556 & 20 & 90698.3 & $21294_{7 / 2}-111993_{9 / 2}^{\circ}$ \\
\hline 1111.117 & 1 & 89999.5 & & 1102.392 & 200 & 90711.8 & $24788_{9 / 2}-115499_{9 / 2}^{\circ}$ \\
\hline 1111.035 & 1 & 90006.2 & $26446_{7 / 2}-116453_{9 / 2}^{\circ}$ & 1101.939 & 20 & 90749.1 & $27452_{5 / 2}-118201_{3 / 2}^{\circ}$ \\
\hline 1110.898 & 1 & 90017.3 & $20315_{9 / 2}-110333_{7 / 2}^{\circ}$ & 1101.757 & 100 & 90764.1 & $22527_{7 / 2}-113291^{\circ}{ }_{7 / 2}$ \\
\hline 1110.656 & 1 & 90036.9 & & 1101.660 & 1 & 90772.1 & \\
\hline 1110.520 & 200 & 90047.9 & $21294_{7 / 2}-111342^{\circ}{ }_{7 / 2}$ & 1101.542 & 1 & 90781.8 & \\
\hline 1110.172 & 30 & 90076.1 & $21418_{5 / 2}-111494_{5 / 2}^{\circ}$ & 1100.673 & 40 & 90853.5 & $24470_{7 / 2}-115324_{9 / 2}^{\circ}$ \\
\hline 1110.082 & 1 & 90083.4 & & 1100.546 & 1 & 90864.0 & $23050_{3 / 2}-113914_{5 / 2}^{\circ}$ \\
\hline 1109.801 & 5 & 90106.2 & & & & & $27604_{9 / 2}-118468_{9 / 2}^{\circ}$ \\
\hline 1109.523 & 15 & 90128.8 & $23651_{7 / 2}-113780_{9 / 2}^{\circ}$ & 1100.515 & 2 & 90866.6 & $27452_{5 / 2}-118318_{7 / 2}^{\circ}$ \\
\hline 1109.156 & 200 & 90158.6 & $28720_{9 / 2}-118879^{\circ}{ }_{11 / 2}$ & 1100.389 & 4 & 90877.0 & $30505_{11 / 2}-121382_{9 / 2}^{\circ}$ \\
\hline 1109.011 & 20 & 90170.4 & & 1099.894 & 4 & 90917.8 & \\
\hline 1108.879 & 10 & 90181.2 & & 1099.803 & 200 & 90925.4 & $30505_{11 / 2}-121431^{\circ}{ }_{13 / 2}$ \\
\hline 1108.817 & 500 & 90186.2 & $23647_{13 / 2}-113833^{\circ}{ }_{15 / 2}$ & 1099.596 & 4 & 90942.5 & $27138_{7 / 2}-118081_{9 / 2}^{\circ}$ \\
\hline 1108.709 & 20 & 90195.0 & $27452_{5 / 2}-117647^{\circ}{ }_{7 / 2}$ & 1099.505 & 20 & 90950.0 & $24470_{7 / 2}-115420_{7 / 2}^{\circ}$ \\
\hline 1108.648 & 3 & 90200.0 & $21294_{7 / 2}-111494_{5 / 2}^{\circ}$ & 1099.389 & 7 & 90959.6 & $24461_{5 / 2}-115420_{7 / 2}^{\circ}$ \\
\hline 1108.115 & 6 & 90243.3 & & 1099.045 & 40 & 90988.1 & $25033_{9 / 2}-116021^{\circ}{ }_{7 / 2}$ \\
\hline
\end{tabular}


TABLE X. Observed spectral lines of Pr III in the vacuum ultra violet region-Continued

\begin{tabular}{|c|c|c|c|c|c|c|c|}
\hline$\lambda_{\mathrm{vac}}$ & Intensity & $\begin{array}{c}\sigma \\
\left(\mathrm{cm}^{-1}\right)\end{array}$ & Classification $^{\text {a }}$ & $\lambda_{\mathrm{vac}}$ & Intensity & $\begin{array}{c}\sigma \\
\left(\mathrm{cm}^{-1}\right)\end{array}$ & Classification $^{a}$ \\
\hline $\begin{array}{l}1098.981 \\
1098.735 \\
1098.573 \\
1098.506\end{array}$ & $\begin{array}{r}3 \\
1 \\
40 \\
4\end{array}$ & $\begin{array}{l}90993.4 \\
91013.8 \\
91027.2 \\
91032.7\end{array}$ & $\begin{array}{l}21755_{11 / 2}-112769^{\circ}{ }_{13 / 2} \\
20315_{9 / 2}-111342^{\circ}{ }_{7 / 2} \\
30505_{11 / 2}-121532^{\circ}{ }_{11 / 2} \\
22747_{9 / 2}-113780^{\circ}{ }_{9 / 2}\end{array}$ & $\begin{array}{l}1091.293 \\
1091.097 \\
1091.047 \\
1090.876\end{array}$ & $\begin{array}{l}2 \\
1 \\
2 \\
2\end{array}$ & $\begin{array}{l}91634.4 \\
91650.9 \\
91655.1 \\
91669.4\end{array}$ & $\begin{array}{l}25409_{7 / 2}-117044_{7 / 2}^{\circ} \\
26446_{7 / 2}-118081_{9 / 2}^{\circ} \\
23844_{9 / 2}-115499_{9 / 2}^{\circ}\end{array}$ \\
\hline $\begin{array}{l}1098.296 \\
1098.243 \\
1098.164 \\
1097.967 \\
1097.595\end{array}$ & $\begin{array}{r}40 \\
20 \\
2 \\
1 \\
100\end{array}$ & $\begin{array}{l}91050.1 \\
91054.5 \\
91061.1 \\
91077.4 \\
91108.3\end{array}$ & $\begin{array}{l}22080_{7 / 2}-113158_{9 / 2}^{\circ} \\
20160_{3 / 2}-111268_{3 / 2}^{\circ}\end{array}$ & $\begin{array}{l}1090.839 \\
1090.739 \\
1090.626 \\
1090.536 \\
1090.366\end{array}$ & $\begin{array}{r}2 \\
5 \\
50 \\
200 \\
10\end{array}$ & $\begin{array}{l}91672.6 \\
91681.0 \\
91690.5 \\
91698.0 \\
91712.3\end{array}$ & $\begin{array}{l}23651_{7 / 2}-115324_{9 / 2}^{\circ} \\
21611_{5 / 2}-113291^{\circ}{ }_{7 / 2} \\
29835_{9 / 2}-121532^{\circ}{ }_{11 / 2} \\
25934_{5 / 2}-117647^{\circ}{ }_{7 / 2}\end{array}$ \\
\hline $\begin{array}{l}1097.148 \\
1096.955 \\
1096.731 \\
1096.367\end{array}$ & $\begin{array}{r}50 \\
1 \\
20 \\
10 h\end{array}$ & $\begin{array}{l}91145.4 \\
91161.4 \\
91180.1 \\
91210.3\end{array}$ & $\begin{array}{l}24788_{9 / 2}-115933_{11 / 2}^{\circ} \\
19700_{11 / 2}-110881_{11 / 2}^{\circ} \\
27138_{7 / 2}-118318_{7 / 2}^{\circ} \\
22080_{7 / 2}-113291_{7 / 2}^{\circ}\end{array}$ & $\begin{array}{l}1090.006 \\
1089.921 \\
1089.844\end{array}$ & $\begin{array}{r}15 \\
1 \\
4\end{array}$ & $\begin{array}{l}91742.6 \\
91749.8 \\
91756.2\end{array}$ & $\begin{array}{l}36640_{7 / 2}-128352^{\circ}{ }_{9 / 2} \\
19360_{13 / 2}-111110^{\circ}{ }_{13 / 2} \\
21535_{9 / 2}-113291^{\circ}{ }_{7 / 2} \\
23647_{13 / 2}-115403^{\circ}{ }_{11 / 2}\end{array}$ \\
\hline $\begin{array}{l}1096.121 \\
1096.080 \\
1095.856 \\
1095.766 \\
1095.587\end{array}$ & $\begin{array}{l}100 \\
50 b l \\
30 \\
100 \\
60\end{array}$ & $\begin{array}{l}91230.8 \\
91234.2 \\
91252.9 \\
91260.4 \\
91275.3\end{array}$ & $\begin{array}{l}27380_{11 / 2}-118610^{\circ}{ }_{13 / 2} \\
24788_{9 / 2}-116021^{\circ}{ }_{7 / 2} \\
22527_{7 / 2}-113780^{\circ} \\
29835_{9 / 2}-121095^{\circ}{ }_{11 / 2}^{\circ} \\
25033_{9 / 2}-116309^{\circ}{ }_{11 / 2}^{\circ}\end{array}$ & $\begin{array}{l}1089.571 \\
1089.464 \\
1089.312 \\
1089.167\end{array}$ & $\begin{array}{r}20 \\
15 \\
8 \\
1\end{array}$ & $\begin{array}{l}91779.2 \\
91788.2 \\
91801.1 \\
91813.3\end{array}$ & $\begin{array}{l}19308_{11 / 2}-111110^{\circ}{ }_{13 / 2} \\
36652_{5 / 2}-128453^{\circ}{ }^{\circ} \\
36640_{7 / 2}-128453^{\circ}{ }_{7 / 2}\end{array}$ \\
\hline $\begin{array}{l}1095.513 \\
1095.403 \\
1094.928 \\
1094.878\end{array}$ & $\begin{array}{l}30 \\
15 \\
80 \\
30\end{array}$ & $\begin{array}{l}91281.4 \\
91290.6 \\
91330.2 \\
91334.4\end{array}$ & $\begin{array}{l}27604_{9 / 2}-118879^{\circ}{ }_{11 / 2} \\
27138_{7 / 2}-118468_{9 / 2}^{\circ} \\
20160_{3 / 2}-111494_{5 / 2}^{\circ}\end{array}$ & $\begin{array}{l}1088.933 \\
1088.879 \\
1088.659 \\
1088.572 \\
1088.353\end{array}$ & $\begin{array}{r}30 \\
3 \\
500 \\
20 \\
10\end{array}$ & $\begin{array}{l}91833.0 \\
91837.6 \\
91856.1 \\
91863.5 \\
91881.9\end{array}$ & $\begin{array}{l}22080_{7 / 2}-113914_{5 / 2}^{\circ} \\
29263_{13 / 2}-121119^{\circ}{ }_{15 / 2} \\
21294_{7 / 2}-113158_{9 / 2}^{\circ} \\
23442_{11 / 2}-115324_{9 / 2}^{\circ}\end{array}$ \\
\hline $\begin{array}{l}1094.832 \\
1094.767 \\
1094.637 \\
1094.486 \\
1094.255\end{array}$ & $\begin{array}{r}1 \\
15 \\
1 \\
30 \\
80\end{array}$ & $\begin{array}{l}91338.2 \\
91343.6 \\
91354.5 \\
91367.1 \\
91386.4\end{array}$ & $\begin{array}{l}24461_{5 / 2}-115800^{\circ}{ }_{5 / 2} \\
18990_{7 / 2}-110333^{\circ}{ }_{7 / 2} \\
23442_{11 / 2}-114797^{\circ}{ }_{13 / 2} \\
22527_{7 / 2}-113914^{\circ}{ }_{5 / 2}\end{array}$ & $\begin{array}{l}1088.284 \\
1088.125 \\
1087.804 \\
1087.601 \\
1087.563\end{array}$ & $\begin{array}{r}10 \\
70 \\
100 \\
4 \\
1\end{array}$ & $\begin{array}{l}91887.8 \\
91901.2 \\
91928.3 \\
91945.5 \\
91948.7\end{array}$ & $\begin{array}{l}23532_{5 / 2}-115420^{\circ}{ }_{7 / 2} \\
36640_{7 / 2}-128568_{9 / 2}^{\circ} \\
21611_{5 / 2}^{\circ}-113556_{5 / 2}^{\circ}\end{array}$ \\
\hline $\begin{array}{l}1094.058 \\
1093.870 \\
1093.601 \\
1093.521 \\
1093.253\end{array}$ & $\begin{array}{r}3 \\
10 \\
1 \\
80 \\
80\end{array}$ & $\begin{array}{l}91402.8 \\
91418.5 \\
91441.0 \\
91447.7 \\
91470.1\end{array}$ & $\begin{array}{l}21755_{11 / 2}-113158_{9 / 2}^{\circ} \\
37011_{5 / 2}-128453^{\circ}{ }_{7 / 2} \\
19872_{7 / 2}-111342^{\circ}{ }_{7 / 2}\end{array}$ & $\begin{array}{l}1087.465 \\
1087.418 \\
1087.362 \\
1087.252 \\
1087.164\end{array}$ & $\begin{array}{l}2 \\
2 \\
1 \\
4 \\
4\end{array}$ & $\begin{array}{l}91957.0 \\
91961.0 \\
91965.7 \\
91974.0 \\
91982.4\end{array}$ & $\begin{array}{l}23442_{11 / 2}-115403^{\circ}{ }_{11 / 2} \\
23442_{11 / 2}-115408^{\circ}{ }_{13 / 2} \\
19360_{13 / 2}-111335^{\circ}{ }_{15 / 2} \\
24470_{7 / 2}-116453_{9 / 2}^{\circ}\end{array}$ \\
\hline $\begin{array}{l}1093.185 \\
1092.910 \\
1092.529 \\
1092.481\end{array}$ & $\begin{array}{r}60 \\
20 \\
2\end{array}$ & $\begin{array}{l}91475.8 \\
91498.8 \\
91530.8 \\
91534.8\end{array}$ & $\begin{array}{l}22080_{7 / 2}-113556^{\circ}{ }_{5 / 2} \\
27380_{11 / 2}-118879^{\circ}{ }_{11 / 2} \\
21238_{13 / 2}-112769^{\circ}{ }_{13 / 2} \\
36683_{1 / 2}-128214^{\circ}{ }_{3 / 2}\end{array}$ & $\begin{array}{l}1087.063 \\
1086.993 \\
1086.700 \\
1086.598 \\
1086.538\end{array}$ & $\begin{array}{r}1 \\
5 \\
40 \\
10 \\
1\end{array}$ & $\begin{array}{l}91991.0 \\
91996.9 \\
92021.7 \\
92030.4 \\
92035.4\end{array}$ & $\begin{array}{l}21294_{7 / 2}-113291^{\circ}{ }_{7 / 2} \\
26446_{7 / 2}-118468_{9 / 2}^{\circ}\end{array}$ \\
\hline 1092.301 & $\begin{array}{l}20 c l \\
20 c l\end{array}$ & $\begin{array}{l}91549.9 \\
91572.4\end{array}$ & $\begin{array}{c}22277_{3 / 2}-113825^{\circ}{ }_{3 / 2} \\
29835_{9 / 2}-121382_{9 / 2}^{\circ} \\
22080_{7 / 2}-113630^{\circ} \\
24250_{3 / 2}^{\circ}-115800^{\circ}{ }_{5 / 2}^{\circ} \\
19308_{11 / 2}-110881_{11 / 2}^{\circ}\end{array}$ & $\begin{array}{l}1086.388 \\
1086.321 \\
1086.280 \\
1085.915 \\
1085.828\end{array}$ & $\begin{array}{r}2 \\
3 \\
2 \\
40 \\
20\end{array}$ & $\begin{array}{l}92048.1 \\
92053.8 \\
92057.3 \\
92088.2 \\
92095.6\end{array}$ & $\begin{array}{l}18241_{11 / 2}-110295^{\circ}{ }_{11 / 2} \\
23442_{11 / 2}-115499_{9 / 2}^{\circ} \\
23844_{9 / 2}-115933_{11 / 2}^{\circ} \\
21535_{9 / 2}-113630^{\circ}{ }_{7 / 2}\end{array}$ \\
\hline $\begin{array}{l}1091.983 \\
1091.676 \\
1091.555 \\
1091.477 \\
1091.430\end{array}$ & $\begin{array}{l}3 \\
1 \\
30 \\
70 \\
30 h\end{array}$ & $\begin{array}{l}91576.5 \\
91602.3 \\
91612.4 \\
91619.0 \\
91622.9\end{array}$ & $23844_{9 / 2}-115420^{\circ}{ }_{7 / 2}$ & $\begin{array}{l}1085.531 \\
1085.435 \\
1085.380 \\
1085.283 \\
1085.236\end{array}$ & $\begin{array}{r}20 \\
1 \\
1 \\
2 \\
10\end{array}$ & $\begin{array}{l}92120.8 \\
92129.0 \\
92133.6 \\
92141.9 \\
92145.8\end{array}$ & $\begin{array}{l}19872_{7 / 2}-111993_{9 / 2}^{\circ} \\
21535_{9 / 2}-113664_{11 / 2}^{\circ}\end{array}$ \\
\hline
\end{tabular}


TABLE X. Observed spectral lines of Pr III in the vacuum ultra violet region-Continued

\begin{tabular}{|c|c|c|c|c|c|c|c|}
\hline $\begin{array}{c}\lambda_{\text {yac }} \\
\AA\end{array}$ & Intensity & $\begin{array}{c}\sigma \\
\left(\mathrm{cm}^{-1}\right)\end{array}$ & Classification $^{\text {a }}$ & $\underset{\AA}{\lambda_{\text {vac }}}$ & Intensity & $\begin{array}{c}\sigma \\
\left(\mathrm{cm}^{-1}\right)\end{array}$ & Classification $^{\text {a }}$ \\
\hline 1085.112 & 8 & 92156.4 & & 1079.013 & 10 & 92677.3 & $21148_{3 / 2}-113825_{3 / 2}^{\circ}$ \\
\hline 1084.976 & 15 & 92167.9 & $29263_{13 / 2}-121431_{13 / 2}^{\circ}$ & 1078.672 & 1 & 92706.6 & $17627_{9 / 2}-110333_{7 / 2}^{\circ}$ \\
\hline 1084.873 & 10 & 92176.7 & $23844_{9 / 2}-116021^{\circ}{ }_{7 / 2}$ & 1078.516 & 2 & 92720.0 & \\
\hline & & & $26095_{11 / 2}-118271^{\circ}{ }_{11 / 2}$ & 1077.972 & 2 & 92766.8 & \\
\hline 1084.417 & 500 & 92215.4 & $41026_{17 / 2}-133242^{\circ}{ }_{19 / 2}$ & 1077.851 & 1 & 92777.2 & \\
\hline 1084.262 & $8 b l$ & 92228.6 & $23175_{13 / 2}-115403^{\circ}{ }_{11 / 2}$ & 1077.782 & 40 & 92783.1 & \\
\hline 1084.204 & 7 & 92233.6 & $23175_{13 / 2}-115408_{13 / 2}^{\circ}$ & 1077.742 & 4 & 92786.6 & $24788_{9 / 2}-117574_{11 / 2}^{\circ}$ \\
\hline 1084.157 & 20 & 92237.6 & $25409_{7 / 2}-117647_{7 / 2}^{\circ}$ & 1077.623 & 2 & 92796.8 & $22527_{7 / 2}-115324_{9 / 2}^{\circ}$ \\
\hline 1084.071 & 1 & 92244.9 & $21535_{9 / 2}-113780_{9 / 2}^{\circ}$ & 1077.571 & 30 & 92801.3 & $23651_{7 / 2}-116453_{9 / 2}^{\circ}$ \\
\hline 1083.936 & 20 & 92256.4 & $24470_{7 / 2}-116727_{5 / 2}^{\circ}$ & 1077.451 & 10 & 92811.6 & $28720_{9 / 2}-121532^{\circ}{ }_{11 / 2}$ \\
\hline & & & $24788_{9 / 2}-117044_{7 / 2}^{\circ}$ & 1077.382 & 20 & 92817.6 & $18063_{9 / 2}-110881_{11 / 2}^{\circ}$ \\
\hline 1083.876 & 40 & 92261.5 & $21294_{7 / 2}-113556_{5 / 2}^{\circ}$ & 1076.902 & 40 & 92856.0 & $18063_{9 / 2}-110922_{9 / 2}^{\circ}$ \\
\hline 1083.815 & 10 & 92266.7 & $23532_{5 / 2}-115800_{5 / 2}^{\circ}$ & & & & $24788_{9 / 2}-117647_{7 / 2}^{\circ}$ \\
\hline 1083.747 & 20 & 92272.4 & $25934_{5 / 2}-118201_{3 / 2}^{\circ}$ & $\begin{array}{l}1076.831 \\
1076.790\end{array}$ & $\begin{array}{r}3 \\
10\end{array}$ & $\begin{array}{l}92865.1 \\
92868.6\end{array}$ & $18241_{11 / 2}-111110_{13 / 2}^{\circ}$ \\
\hline 1083.697 & 2 & 92276.7 & $25409_{7 / 2}-117686_{5 / 2}^{\circ}$ & 1076.708 & 2 & 92875.7 & \\
\hline 1083.548 & 5 & 92289.4 & $18241_{11 / 2}-110530_{13 / 2}^{\circ}$ & 1076.325 & 30 & 92908.7 & $25409_{7 / 2}-118318_{7 / 2}^{\circ}$ \\
\hline & & & $25033_{9 / 2}-117323^{\circ}{ }_{11 / 2}$ & 1076.137 & 5 & 92925.0 & \\
\hline 1083.393 & 10 & 92302.6 & $21611_{5 / 2}-113914_{5 / 2}^{\circ}$ & 1075.961 & 100 & 92940.2 & \\
\hline 1083.348 & 20 & 92306.4 & & 1075.707 & 2 & 92962.1 & \\
\hline 1083.285 & 1 & 92311.8 & & 1075.586 & $10 c l$ & 92972.6 & $22527_{7 / 2}-115499^{\circ}{ }_{9 / 2}$ \\
\hline 1083.001 & 10 & 92336.0 & $21294_{7 / 2}-113630^{\circ}{ }_{7 / 2}$ & 1075.565 & $50 \mathrm{cl}$ & 92974.4 & \\
\hline 1082.881 & 40 & 92346.2 & $41026_{17 / 2}-133373^{\circ}{ }_{17 / 2}$ & 1075.532 & $10 c l$ & 92977.2 & $20848_{5 / 2}-113825_{3 / 2}^{\circ}$ \\
\hline 1082.824 & 8 & 92351.1 & & 1075.448 & 1 & 92984.5 & \\
\hline 1082.704 & 50 & 92361.4 & $21238_{13 / 2}-113600^{\circ}{ }_{13 / 2}$ & 1075.147 & 1 & 93010.5 & $23442_{11 / 2}-116453_{9 / 2}^{\circ}$ \\
\hline 1082.445 & 8 & 92383.4 & $25934_{5 / 2}-118318_{7 / 2}^{\circ}$ & 1074.855 & 100 & 93035.8 & \\
\hline 1082.091 & 20 & 92413.7 & $18921_{15 / 2}-111335_{15 / 2}^{\circ}$ & 1074.726 & 5 & 93047.0 & $25033_{9 / 2}-118081_{9 / 2}^{\circ}$ \\
\hline 1082.045 & 10 & 92417.6 & $24309_{3 / 2}-116727^{\circ}{ }_{5 / 2}^{\circ}$ & 1074.669 & 40 & 93051.9 & \\
\hline 1081.807 & 3 & 92437.9 & & 1074.590 & 7 & 93058.8 & $25409_{7 / 2}-118468_{9 / 2}^{\circ}$ \\
\hline 1081.746 & 10 & 92443.1 & $20848_{5 / 2}-113291^{\circ}{ }_{7 / 2}$ & 1074.515 & 100 & 93065.2 & $20848_{5 / 2}^{7 / 2}-113914_{5 / 2}^{\circ}$ \\
\hline 1081.574 & 3 & 92457.8 & & 1074.474 & 5 & 93068.8 & $19700_{11 / 2}-112769^{\circ}{ }_{13 / 2}$ \\
\hline 1081.356 & 20 & 92476.5 & $24250_{3 / 2}-116727^{\circ}{ }_{5 / 2}$ & 1074.353 & 7 & 93079.3 & $24461_{5 / 2}-117540_{3 / 2}^{\circ}$ \\
\hline 1081.252 & 5 & 92485.4 & $21294_{7 / 2}-113780^{\circ}$ & 1074.171 & 5 & 93095.0 & \\
\hline 1081.210 & 5 & 92489.0 & $23532_{5 / 2}-116021^{\circ}{ }_{7 / 2}$ & 1074.041 & 5 & 93106.3 & \\
\hline 1080.898 & 100 & 92515.7 & $26095_{11 / 2}-118610^{\circ}{ }_{13 / 2}$ & 1073.901 & 200 & 93118.4 & $27380_{11 / 2}-120498^{\circ}{ }_{13 / 2}$ \\
\hline 1080.797 & 6 & 92524.3 & $35828_{9 / 2}-128352_{9 / 2}^{\circ}$ & 1073.801 & 1 & 93127.1 & \\
\hline 1080.553 & 2 & 92545.2 & & 1073.661 & 100 & 93139.3 & \\
\hline 1080.459 & 300 & 92553.3 & $35828_{9 / 2}-128381_{11 / 2}^{\circ}$ & 1073.340 & 20 & 93167.1 & \\
\hline 1080.187 & 50 & 92576.6 & $22747_{9 / 2}-115324_{9 / 2}^{\circ}$ & 1073.308 & 3 & 93169.9 & \\
\hline 1080.110 & 20 & 92583.2 & $24461_{5 / 2}-117044_{7 / 2}^{\circ}$ & 1073.126 & 200 & 93185.7 & $22747_{9 / 2}-115933^{\circ}{ }_{11 / 2}$ \\
\hline 1080.019 & 2 & 92591.0 & & 1072.600 & 30 & 93231.4 & $24309_{3 / 2}-117540_{3 / 2}^{\circ}$ \\
\hline 1079.947 & 3 & 92597.1 & & 1072.529 & 100 & 93237.6 & $25033_{9 / 2}-118271_{11 / 2}^{\circ / 2}$ \\
\hline 1079.921 & 10 & 92599.4 & & 1072.466 & 20 & 93243.0 & $22080_{7 / 2}-115324_{9 / 2}^{\circ}$ \\
\hline 1079.727 & 10 & 92616.0 & & 1072.425 & 5 & 93246.6 & $19649_{17 / 2}-112896^{\circ}{ }_{15 / 2}$ \\
\hline 1079.698 & 10 & 92618.5 & & 1072.342 & 20 & 93253.8 & $17627_{9 / 2}-110881^{\circ}{ }_{11 / 2}$ \\
\hline 1079.452 & 100 & 92639.6 & $18241_{11 / 2}-110881_{11 / 2}^{\circ}$ & 1072.237 & 8 & 93263.0 & \\
\hline 1079.268 & 60 & 92655.4 & $22747_{9 / 2}-115403^{\circ}{ }_{11 / 2}$ & 1072.108 & $50 \mathrm{cl}$ & 93274.2 & $22747_{9 / 2}-116021_{7 / 2}^{\circ}$ \\
\hline 1079.204 & 1 & 92660.9 & $23647_{13 / 2}-116309^{\circ}{ }_{11 / 2}$ & 1072.076 & $10 \mathrm{cl}$ & 93277.0 & $35291_{9 / 2}-128568_{9 / 2}^{\circ}$ \\
\hline 1079.078 & $50 \mathrm{cl}$ & 92671.7 & $25409_{7 / 2}-118081_{9 / 2}^{\circ}$ & 1072.009 & 100 & 93282.8 & \\
\hline 1079.058 & $50 \mathrm{cl}$ & 92673.4 & $22747_{9 / 2}-115420_{7 / 2}^{\circ}$ & 1071.968 & 10 & 93286.4 & $19872_{7 / 2}-113158_{9 / 2}^{\circ}$ \\
\hline
\end{tabular}

${ }^{a}$ For doubly-classified lines, the wavelength is entered only once. 
TABlE X. Observed spectral lines of Pr III in the vacuum ultra violet region-Continued

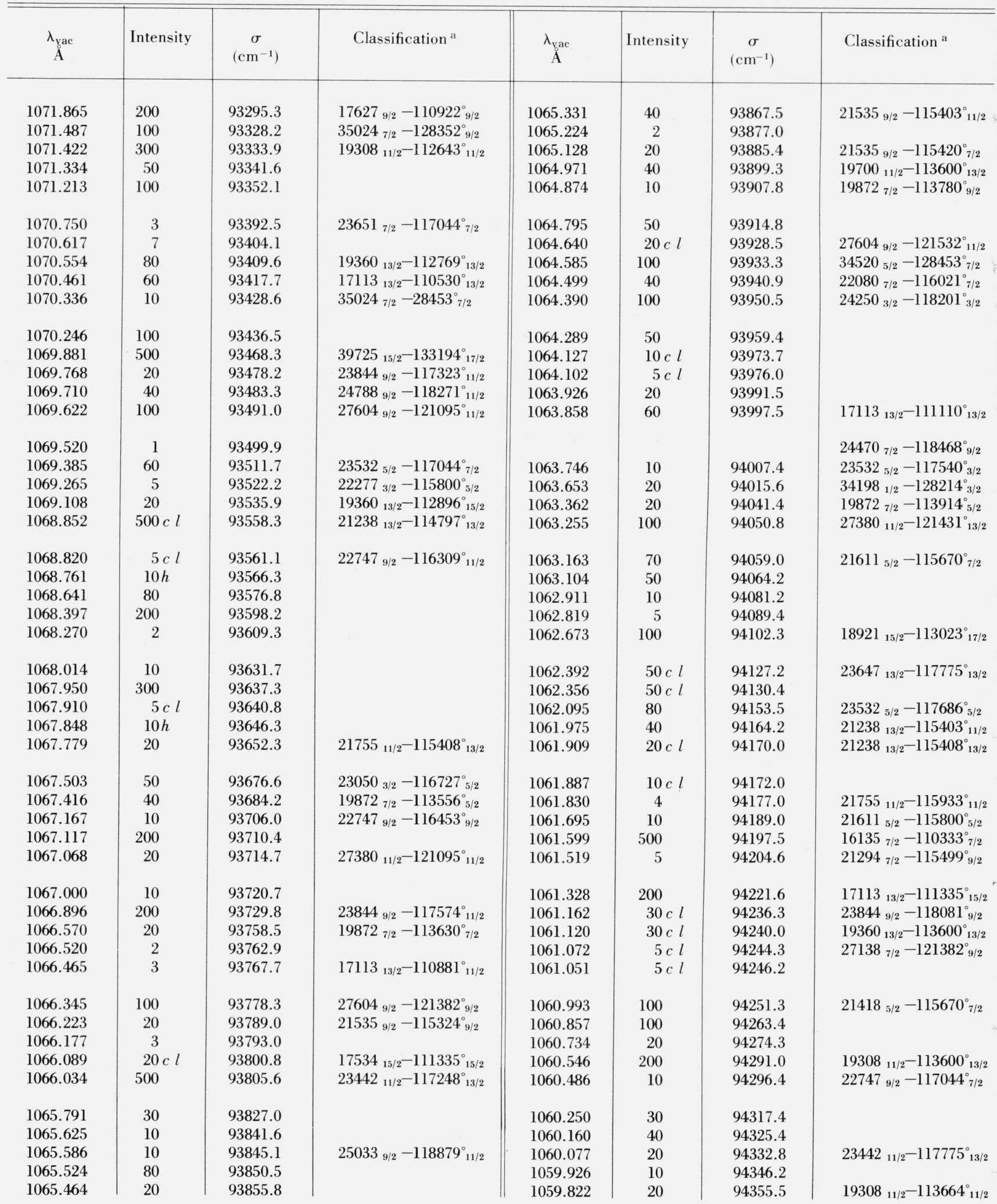


TABLE X. Observed spectral lines of Pr III in the vacuum ultra violet region-Continued

\begin{tabular}{|c|c|c|c|c|c|c|c|}
\hline$\stackrel{\lambda_{\text {yac }}}{\AA}$ & Intensity & $\begin{array}{c}\sigma \\
\left(\mathrm{cm}^{-1}\right)\end{array}$ & Classification $^{\mathrm{a}}$ & $\underset{\mathrm{A}}{\lambda_{\mathrm{Vac}}}$ & Intensity & $\begin{array}{c}\sigma \\
\left(\mathrm{cm}^{-1}\right)\end{array}$ & Classification $^{\text {a }}$ \\
\hline 1059.714 & 10 & 94365.1 & & 1053.177 & 1 & 94950.8 & \\
\hline 1059.631 & $100 \mathrm{cl}$ & 94372.5 & $22080_{\tau / 2}-116453_{9 / 2}^{\circ}$ & 1053.105 & 1 & 94957.3 & \\
\hline 1059.587 & $100 \mathrm{cl}$ & 94376.4 & & 1053.021 & 100 & 94964.9 & \\
\hline 1059.410 & 50 & 94392.2 & & 1052.860 & $100 \mathrm{cl}$ & 94979.4 & \\
\hline 1059.281 & $400 \mathrm{cl}$ & 94403.7 & $26095_{11 / 2}-120498^{\circ}{ }_{13 / 2}$ & 1052.815 & 40 & 94983.4 & \\
\hline 1059.250 & $100 \mathrm{cl}$ & 94406.4 & $16516_{7 / 2}-110922_{9 / 2}^{\circ}$ & 1052.633 & 1000 & 94999.9 & $21238_{13 / 2}-116238^{\circ}{ }_{15 / 2}$ \\
\hline 1059.157 & 200 & 94414.7 & & 1052.571 & 100 & 95005.5 & $15525_{11 / 2}-110530^{\circ}{ }_{13 / 2}$ \\
\hline 1059.022 & 60 & 94426.8 & $23844_{9 / 2}-118271^{\circ}{ }_{11 / 2}$ & 1052.456 & 3 & 95015.8 & $17627_{9 / 2}-112643^{\circ}{ }_{11 / 2}$ \\
\hline $\begin{array}{l}1058.948 \\
1058.769\end{array}$ & $\begin{array}{l}10 \\
60\end{array}$ & $\begin{array}{l}94433.3 \\
944493\end{array}$ & $\begin{array}{l}21238_{13 / 2}-115672^{\circ}{ }_{15 / 2}^{\circ} \\
22277^{\circ}-11677^{\circ}\end{array}$ & $\begin{array}{l}1052.262 \\
1052202\end{array}$ & 3 & 95033.4 & \\
\hline 1058.769 & 60 & 94449.3 & $22277_{3 / 2}-116727_{5 / 2}^{\circ}$ & 1052.202 & $5 \mathrm{cl}$ & 95038.8 & \\
\hline 1058.510 & 100 & 94472.4 & & 1052.133 & $5 c l$ & 95045.0 & \\
\hline 1058.393 & 3 & 94482.9 & & 1051.929 & 30 & 95063.4 & \\
\hline 1058.348 & 3 & 94486.9 & $21535_{9 / 2}-116021_{7 / 2}^{\circ}$ & 1051.851 & 5 & 95070.5 & $21238_{13 / 2}-116309^{\circ}{ }_{11 / 2}$ \\
\hline 1058.150 & 4 & 94504.6 & $21294_{7 / 2}-115800_{5 / 2}^{\circ}$ & 1051.792 & 200 & 95075.8 & $19649_{17 / 2}-114725^{\circ} 17 / 2$ \\
\hline 1058.018 & 20 & 94516.4 & $22527_{7 / 2}-117044^{\circ}{ }_{7 / 2}$ & 1051.732 & 40 & 95081.2 & \\
\hline 1057.903 & $5 c l$ & 94526.6 & & 1051.568 & 200 & 95096.1 & $19700_{11 / 2}-114797^{\circ}{ }_{13 / 2}$ \\
\hline 1057.885 & $10 \mathrm{cl}$ & 94528.2 & $18241_{11 / 2}-112769^{\circ}{ }_{13 / 2}$ & 1051.423 & 30 & 95109.2 & \\
\hline 1057.783 & 100 & 94537.3 & & 1051.347 & 5 & 95116.1 & $21611_{5 / 2}-116727_{5 / 2}^{\circ}$ \\
\hline 1057.721 & 100 & 94542.9 & & 1051.313 & 20 & 95119.2 & $22527_{7 / 2}-117647_{7 / 2}^{\circ}$ \\
\hline 1057.490 & $10 \mathrm{cl}$ & 94563.5 & & 1051.093 & 10 & 95139.1 & \\
\hline 1057.456 & 20 & 94566.6 & $18990_{7 / 2}-113556_{5 / 2}^{\circ}$ & 1050.961 & 5 & 95151.0 & $23050_{3 / 2}-118201_{3 / 2}^{\circ}$ \\
\hline 1057.310 & 400 & 945796 & $38785_{15 / 2}-133352^{\circ}{ }_{15 / 2}$ & 1050.881 & 10 & 95158.2 & $21294_{7 / 2}-116453_{9 / 2}^{\circ}$ \\
\hline 1057.228 & 200 & $\begin{array}{l}945 / 9.0 \\
94587.0\end{array}$ & $18063_{9 / 2}-112643_{11 / 2}$ & & & & $22527_{7 / 2}-117686_{5 / 2}^{\circ}$ \\
\hline 1057.080 & 40 & 94600.2 & $38785_{15 / 2}-133373^{17 / 2}$ & 1050.770 & 1 & 95168.3 & $23442_{11 / 2}-118610^{\circ}{ }_{13 / 2}$ \\
\hline & & & $2016,13 / 2=1161013 / 2$ & 1050.652 & 7 & 95179.0 & \\
\hline 1056.815 & 10 & 94623.9 & $\begin{array}{l}23647{ }_{13 / 2}-118271_{11 / 2}^{\circ} \\
23844\end{array}$ & 1050.595 & 3 & 95184.2 & $20315_{9 / 2}-115499_{9 / 2}^{\circ}$ \\
\hline 1056.619 & 8 & 94641.5 & & $\begin{array}{l}1050.433 \\
1050.323\end{array}$ & $\begin{array}{r}20 \\
100\end{array}$ & $\begin{array}{l}95198.8 \\
95208.8\end{array}$ & \\
\hline 1056.518 & 100 & 94650.5 & $38701_{13 / 2}-133352^{\circ}{ }_{15 / 2}$ & 1050.107 & 70 & 95228.4 & $18063_{9 / 2}-113291_{7 / 2}^{\circ}$ \\
\hline 1056.314 & 20 & 94668.8 & $23532_{5 / 2}-118201_{3 / 2}^{\circ}$ & 1050.056 & 20 & 95233.0 & \\
\hline 1056.211 & 50 & 94678.0 & & 1049.914 & 1 & 95245.9 & \\
\hline 1056.030 & 80 & 94694.3 & $21238_{13 / 2}-115933_{11 / 2}^{\circ}$ & 1049.546 & 20 & 95279.3 & \\
\hline 1055.857 & 20 & 94709.8 & & 1049.456 & 100 & 95287.5 & $15045_{5 / 2}-110333^{\circ}{ }^{\circ}$ \\
\hline 1055.668 & 20 & 94726.8 & $21294_{7 / 2}-116021^{\circ}{ }^{\circ}$ & & & & $26095_{11 / 2}-121382_{9 / 2}^{\circ}$ \\
\hline 1055.297 & 20 & 94760.0 & & 1049.228 & 20 & 95308.2 & $21418_{5 / 2}-116727_{5 / 2}^{\circ}$ \\
\hline 1055.143 & 300 & 94773.9 & $21535_{9 / 2}-116309^{\circ}{ }_{11 / 2}$ & 1049.086 & 2000 & 95321.1 & $19649_{17 / 2}-114970^{\circ}{ }_{19 / 2}$ \\
\hline 1055.072 & 30 & 94780.3 & & 1048.951 & 5 & 95333.3 & $22747_{9 / 2}-118081_{9 / 2}^{\circ}$ \\
\hline 1054.613 & 50 & 94821.5 & $20848_{5 / 2}-115670^{\circ}{ }_{7 / 2}$ & 1048.923 & 15 & 95335.9 & $26095_{11 / 2}-121431^{\circ}{ }_{13 / 2}^{\circ}$ \\
\hline 1054.558 & $50 \mathrm{cl}$ & 94826.5 & $16516_{7 / 2}-111342^{\circ}{ }_{7 / 2}$ & 1048.703 & $100 \mathrm{cl}$ & 95355.9 & $15525_{11 / 2}-110881^{\circ}{ }_{11 / 2}$ \\
\hline 1054.525 & $80 \mathrm{cl}$ & 94829.4 & $23442_{11 / 2}-118271^{\circ}{ }_{11 / 2}$ & 1048.672 & $20 \mathrm{cl}$ & 95358.7 & $\begin{array}{l}16135_{7 / 2}-111494_{5 / 2}^{\circ} \\
18241_{11 / 2}-113600^{\circ}{ }_{13 / 2}\end{array}$ \\
\hline 1054.441 & 60 & 94837.0 & & & & & \\
\hline 1054.388 & 5 & $\begin{array}{l}94841.7 \\
948530\end{array}$ & & 1048.643 & $\begin{array}{c}200 \mathrm{cl} \\
3\end{array}$ & $\begin{array}{l}95361.3 \\
05382 ?\end{array}$ & $17534_{15 / 2}-112896^{\circ}{ }_{15 / 2}$ \\
\hline $\begin{array}{l}1054.263 \\
1053.876\end{array}$ & $\begin{array}{r}7 \\
400\end{array}$ & $\begin{array}{l}94853.0 \\
94887.8\end{array}$ & $23175_{13 / 2}-118063^{\circ}{ }_{15 / 2}$ & $\begin{array}{l}1040.413 \\
1048.318\end{array}$ & $\begin{array}{l}3 \\
4\end{array}$ & $\begin{array}{l}9382.2 \\
95390.9\end{array}$ & \\
\hline 1053.584 & 6 & 94914.1 & & 1048.255 & 40 & 95396.6 & $15525_{11 / 2}-110922_{9 / 2}^{\circ}$ \\
\hline 1053.542 & 3 & 94917.9 & $\begin{array}{l}18241_{11 / 2}-113158_{9 / 2}^{\circ} \\
215355_{9 / 2}-116453_{9 / 2}^{\circ}\end{array}$ & 1048.122 & $\begin{array}{l}7 \\
3\end{array}$ & 95408.7 & $22277_{3 / 2}-117686_{5 / 2}^{\circ}$ \\
\hline 1053.412 & 1 & 94929.6 & & $\begin{array}{l}1047.966 \\
1047.924\end{array}$ & 8 & $\begin{array}{l}95422.9 \\
95426.8\end{array}$ & $\begin{array}{l}18241_{11 / 2}-113664^{{ }_{11 / 2}} \\
15454_{13 / 2}-110881_{11 / 2}^{\circ}\end{array}$ \\
\hline 1053.344 & 40 & 94935.8 & $26446_{7 / 2}-121382_{9 / 2}^{\circ}$ & 1047.811 & 100 & 95437.1 & $19360_{13 / 2}-114797^{\circ}{ }_{13 / 2}$ \\
\hline 1053.260 & 2 & 94943.3 & & & & & $23442_{11 / 2}-118879^{\circ}{ }_{11 / 2}$ \\
\hline
\end{tabular}

${ }^{a}$ For doubly-classified lines, the wavelength is entered only once. 
TABLE X. Observed spectral lines of Pr III in the vacuum ultra violet region-Continued

\begin{tabular}{|c|c|c|c|c|c|c|c|}
\hline$\lambda_{\mathrm{vac}}$ & Intensity & $\begin{array}{c}\sigma \\
\left(\mathrm{cm}^{-1}\right)\end{array}$ & Classification $^{\text {a }}$ & $\lambda_{\mathrm{vac}}$ & Intensity & $\begin{array}{c}\sigma \\
\left(\mathrm{cm}^{-1}\right)\end{array}$ & Classification $^{a}$ \\
\hline 1047.752 & 1 & 95442.4 & & 1041.872 & 100 & 95981.1 & \\
\hline 1047.625 & 10 & 95454.0 & & 1041.740 & 100 & 95993.2 & $20315_{9 / 2}-116309^{\circ}{ }_{11 / 2}$ \\
\hline 1047.375 & $10 c l$ & 95476.8 & $16516_{7 / 2}-111993_{9 / 2}^{\circ}$ & 1041.625 & 100 & 96003.8 & $17627_{9 / 2}-113630_{7 / 2}^{\circ}$ \\
\hline 1047.352 & $10 \mathrm{cl}$ & 95478.9 & & 1041.563 & 20 & 96009.6 & $21238_{13 / 2}-117248_{13 / 2}^{\circ}$ \\
\hline 1047.244 & 3000 & 95488.7 & $17534_{15 / 2}-113023^{\circ}{ }_{17 / 2}$ & 1041.459 & 400 & 96019.1 & $21755_{11 / 2}-117775^{\circ}{ }_{13 / 2}$ \\
\hline 1047.105 & 3 & 95501.4 & & 1041.260 & 200 & 96037.5 & $17627_{9 / 2}-113664_{11 / 2}^{\circ}$ \\
\hline 1047.048 & 1 & 95506.6 & & 1041.205 & 20 & 96042.6 & $19360_{13 / 2}-115403^{\circ}{ }_{11 / 2}$ \\
\hline 1046.941 & 3 & 95516.4 & & 1041.145 & 100 & 96048.1 & $19360_{13 / 2}-115408^{\circ}{ }_{13 / 2}$ \\
\hline 1046.779 & 300 & 95531.1 & & 1041.002 & 60 & 96061.3 & $25033_{9 / 2}-121095^{\circ} 11 / 2$ \\
\hline 1046.700 & 20 & 95538.4 & & 1040.849 & 10 & 96075.4 & $21611_{5 / 2}^{9 / 2}-117686_{5 / 2}^{\circ}$ \\
\hline 1046.594 & 1 & 95548.0 & $19872_{7 / 2}-115420_{7 / 2}^{\circ}$ & 1040.646 & 50 & 96094.2 & $19308_{11 / 2}-115403^{\circ}{ }_{11 / 2}$ \\
\hline 1046.543 & 1 & 95552.7 & & 1040.591 & 100 & 96099.2 & $19308_{11 / 2}-115408_{13 / 2}^{\circ}$ \\
\hline 1046.195 & 500 & 95584.5 & $15525_{11 / 2}-111110^{\circ}{ }_{13 / 2}$ & 1040.437 & 6 & 96113.5 & \\
\hline 1046.113 & 10 & 95592.0 & & 1040.387 & 3 & 96118.1 & \\
\hline 1046.014 & 30 & 95601.0 & $18063_{9 / 2}-113664_{11 / 2}^{\circ}$ & 1040.247 & 20 & 96131.0 & $22747_{9 / 2}-118879^{\circ}{ }_{1 / 2}$ \\
\hline 1045.900 & 10 & 95611.4 & & 1040.180 & 100 & 96137.2 & $20315_{9 / 2}-116453_{9 / 2}^{\circ}$ \\
\hline 1045.858 & 100 & 95615.3 & & 1040.139 & 50 & 96141.0 & \\
\hline 1045.765 & 5 & 95623.8 & $19700_{11 / 2}-115324_{9 / 2}^{\circ}$ & 1040.082 & 5 & 96146.3 & \\
\hline 1045.707 & 20 & 95629.1 & & 1040.051 & 5 & 96149.1 & $19872_{7 / 2}-116021_{7 / 2}^{\circ}$ \\
\hline 1045.511 & $10 b l$ & 95647.0 & & 1039.943 & 10 & 96159.1 & \\
\hline 1045.447 & $20 \mathrm{cl}$ & $9565 Q .9$ & & 1039.778 & 50 & 96174.4 & \\
\hline 1045.411 & $300 c l$ & 95656.2 & $15454_{13 / 2}-111110^{\circ}{ }_{13 / 2}$ & 1039.380 & 10 & 96211.2 & \\
\hline 1045.248 & 8 & 95671.1 & $14859_{11 / 2}-110530^{\circ}{ }_{13 / 2}$ & 1039.253 & $60 c l$ & 96223.0 & $15045_{5 / 2}-111268_{3 / 2}^{\circ}$ \\
\hline 1045.181 & 1 & 95677.2 & & 1039.200 & $50 \mathrm{cl}$ & 96227.9 & $21418_{5 / 2}-117647_{7 / 2}^{\circ}$ \\
\hline 1045.049 & 1 & 95689.3 & & 1039.156 & $100 c l$ & 96231.9 & $19700_{11 / 2}-115933^{\circ}{ }_{11 / 2}$ \\
\hline 1044.993 & 4 & 95694.4 & & 1039.033 & 5 & 96243.3 & \\
\hline 1044.909 & 30 & 95702.1 & $18211_{5 / 2}-113914_{5 / 2}^{\circ}$ & 1038.962 & 10 & 96249.9 & $14859_{11 / 2}-111110_{13 / 2}^{\circ}$ \\
\hline & & & $19700_{11 / 2}-115403_{11 / 2}^{\circ}$ & 1038.773 & 3 & 96267.4 & $21418_{5 / 2}-117686_{5 / 2}^{\circ}$ \\
\hline 1044.851 & 10 & 95707.4 & $19700_{11 / 2}-115408^{\circ}{ }_{13 / 2}$ & 1038.451 & 10 & 96297.3 & $15045_{5 / 2}-111342^{\circ}{ }_{7 / 2}$ \\
\hline 1044.608 & 30 & 95729.7 & & 1038.356 & 7 & 96306.1 & \\
\hline 1044.239 & 50 & 95763.5 & & 1038.293 & 1000 & 96311.9 & $19360_{13 / 2}-115672_{15 / 2}^{\circ}$ \\
\hline 1044.203 & 50 & 95766.8 & & 1038.186 & 400 & 96321.8 & $14558_{9 / 2}-110881_{11 / 2}^{\circ}$ \\
\hline 1044.117 & 3 & 95774.7 & $14558_{9 / 2}-110333_{7 / 2}^{\circ}$ & 1038.066 & 40 & 96333.0 & \\
\hline 1044.029 & 500 & 95782.8 & $17113_{13 / 2}-112896_{15 / 2}^{\circ}$ & 1037.862 & 5 & 96351.9 & $21294_{7 / 2}-117647_{7 / 2}^{\circ}$ \\
\hline 1043.970 & 3 & 95788.2 & $21535_{9 / 2}-117323^{\circ}{ }_{11 / 2}$ & 1037.738 & $50 c l$ & 96363.4 & $14558_{9 / 2}-110922_{9 / 2}^{\circ}$ \\
\hline 1043.853 & 50 & 95798.9 & $19700_{11 / 2}-115499_{9 / 2}^{\circ}$ & 1037.703 & $50 c l$ & 96366.7 & \\
\hline 1043.797 & 500 & 95804.1 & $18921_{15 / 2}-114725^{\circ}{ }_{17 / 2}$ & 1037.584 & 20 & 96377.7 & \\
\hline 1043.639 & 10 & 95818.6 & $21755_{11 / 2}-117574_{11 / 2}^{\circ}$ & 1037.479 & 5 & 96387.5 & $22080_{7 / 2}-118468_{9 / 2}^{\circ}$ \\
\hline 1043.501 & 50 & 95831.2 & & 1037.432 & 2 & 96391.9 & $21148_{3 / 2}-117540_{3 / 2}^{\circ}$ \\
\hline 1043.294 & 5 & 95850.2 & & & & & $21294_{7 / 2}-117686_{5 / 2}^{\circ}$ \\
\hline 1043.223 & 200 & 95856.8 & $16135_{7 / 2}-111993_{9 / 2}^{\circ}$ & 1037.390 & 30 & 96395.8 & \\
\hline 1043.110 & 10 & 95867.2 & & 1037.232 & 10 & 96410.4 & $31803_{1 / 2}-128214_{3 / 2}^{\circ}$ \\
\hline 1042.964 & 1000 & 95880.6 & $15454_{13 / 2}-111335_{15 / 2}^{\circ}$ & 1036.823 & 15 & 96448.5 & \\
\hline 1042.819 & 10 & 95893.9 & & 1036.749 & 5 & 96455.4 & \\
\hline 1042.651 & 7 & 95909.4 & & 1036.623 & 10 & 96467.1 & $15525_{11 / 2}-111993_{9 / 2}^{\circ}$ \\
\hline 1042.478 & 100 & 95925.3 & $32288_{3 / 2}-128214_{3 / 2}^{\circ}$ & 1036.410 & 60 & 96486.9 & $17113_{13 / 2}-113600^{\circ}{ }_{13 / 2}$ \\
\hline 1042.306 & 2 & 95941.1 & $22527_{7 / 2}-118468_{9 / 2}^{\circ}$ & & & & $18921_{15 / 2}-115408^{\circ}{ }_{13 / 2}$ \\
\hline 1042.250 & 20 & 95946.3 & & 1036.174 & $40 c l$ & 96508.9 & \\
\hline 1042.031 & 3 & 95966.4 & & 1036.151 & $40 \mathrm{cl}$ & 96511.0 & \\
\hline 1041.963 & 60 & 95972.7 & $25409_{7 / 2}-121382_{9 / 2}^{\circ}$ & 1035.765 & $8 b l$ & 96547.0 & \\
\hline
\end{tabular}


TABLE X. Observed spectral lines of $\operatorname{Pr}$ III in the vacuum ultra violet region-Continued

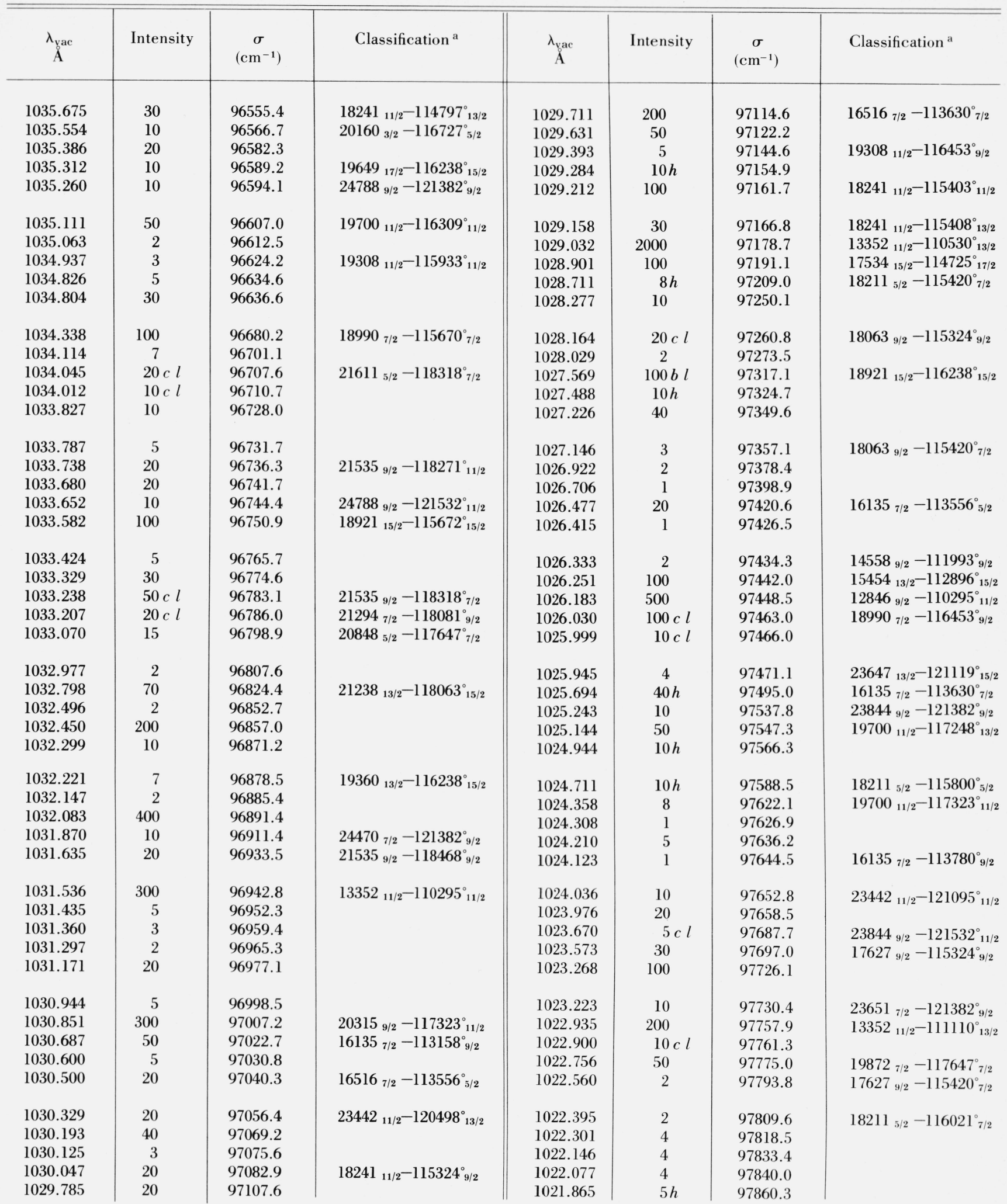


TABLE X. Observed spectral lines of Pr III in the vacuum ultra violet region - Continued

\begin{tabular}{|c|c|c|c|c|c|c|c|}
\hline$\underset{\AA}{\lambda_{\text {yac }}}$ & Intensity & $\begin{array}{c}\sigma \\
\left(\mathrm{cm}^{-1}\right)\end{array}$ & Classification $^{\mathrm{a}}$ & $\underset{\mathrm{fac}}{\AA}$ & Intensity & $\begin{array}{c}\sigma \\
\left(\mathrm{cm}^{-1}\right)\end{array}$ & Classification $^{\text {a }}$ \\
\hline 1021.764 & 1 & 97867.0 & $18063_{9 / 2}-115933^{\circ}{ }_{11 / 2}$ & 1013.841 & 4 & 98634.8 & $22747_{9 / 2}-121382_{9 / 2}^{\circ}$ \\
\hline 1021.726 & 30 & 97873.6 & $\begin{array}{l}17534_{15 / 2}-115408^{\circ}{ }_{13 / 2} \\
19700_{11 / 2}-117574_{11 / 2}^{\circ}\end{array}$ & $\begin{array}{l}1013.780 \\
1013.462\end{array}$ & $\begin{array}{r}30 \\
100\end{array}$ & $\begin{array}{l}98640.7 \\
98671.7\end{array}$ & $13352_{11 / 2}-111993_{9 / 2}^{\circ}$ \\
\hline 1021.664 & 7 & 97879.5 & & 1013.354 & 5 & 98682.2 & $17627_{9 / 2}-116309^{\circ}{ }_{11 / 2}$ \\
\hline 1021.578 & 15 & 97887.8 & $19360_{13 / 2}-117248_{13 / 2}^{\circ}$ & 1013.142 & 80 & 98702.8 & $19360_{13 / 2}-118063^{\circ}{ }_{15 / 2}$ \\
\hline 1021.352 & 1000 & 97909.4 & $14859_{11 / 2}-112769^{\circ}{ }_{13 / 2}$ & 1012.832 & 5 & 98733.1 & $14558_{9 / 2}-113291^{\circ}$ \\
\hline 1021.150 & 20 & 97928.8 & & & & & $29835_{9 / 2}-128568_{9 / 2}^{\circ}$ \\
\hline 1021.039 & 7 & 97939.4 & $19308_{11 / 2}-117248^{\circ}{ }_{13 / 2}$ & 1012.760 & 1 & 98740.1 & $14859_{11 / 2}-113600^{\circ}{ }_{13 / 2}$ \\
\hline 1020.990 & 50 & 97944.2 & $23175_{13 / 2}-121119^{\circ}{ }_{15 / 2}$ & 1012.300 & 2 & 98784.9 & $22747_{9 / 2}-121532^{\circ}{ }_{11 / 2}$ \\
\hline 1020.609 & 10 & 97980.7 & & 1012.101 & 400 & 98804.4 & $14859_{11 / 2}-113664_{11 / 2}^{\circ}$ \\
\hline 1020.252 & 5 & 98015.0 & & 1011.809 & 50 & 98832.9 & $18211_{5 / 2}-117044_{7 / 2}^{\circ}$ \\
\hline 1020.189 & 5 & 98021.0 & & 1011.307 & 10 & 98881.9 & \\
\hline 1020.052 & 40 & 98034.2 & $12846_{9 / 2}-110881_{11 / 2}^{\circ}$ & 1011.012 & 60 & 98910.8 & \\
\hline 1019.982 & 2 & 98040.9 & $20160_{3 / 2}-118201_{3 / 2}^{\circ}$ & 1010.914 & 10 & 98920.4 & $14859_{11 / 2}-113780_{9 / 2}^{\circ}$ \\
\hline 1019.890 & 10 & 98049.8 & & 1010.560 & 50 & 98955.0 & $17534_{15 / 2}-116489^{\circ}{ }_{17 / 2}$ \\
\hline 1019.699 & 1 & 98068.2 & $18241_{11 / 2}-116309^{\circ}{ }_{11 / 2}$ & 1010.282 & 20 & 98982.3 & \\
\hline 1019.631 & 60 & 98074.7 & $15525_{11 / 2}-113600^{\circ}{ }_{13 / 2}$ & 1010.153 & 20 & 98994.9 & \\
\hline & & & $19700_{11 / 2}-117775_{13 / 2}^{\circ}$ & 1010.034 & 20 & 99006.6 & $18241_{11 / 2}-117248^{\circ}{ }_{13 / 2}$ \\
\hline 1019.534 & 60 & 98084.0 & $14558_{9 / 2}-112643^{\circ}{ }_{11 / 2}$ & 1009.750 & 1 & 99034.4 & \\
\hline 1019.474 & 1 & 98089.8 & $23442_{11 / 2}-121532^{\circ}{ }_{11 / 2}$ & 1009.570 & 1 & 99052.1 & \\
\hline 1019.311 & 100 & 98105.5 & & 1009.029 & 1 & 99105.2 & $14558_{9 / 2}-113664^{\circ}{ }_{11 / 2}$ \\
\hline 1019.207 & 2 & 98115.5 & & 1008.938 & 1 & 99114.1 & \\
\hline 1018.968 & 200 & 98138.5 & $15525_{11 / 2}-113664_{11 / 2}^{\circ}$ & 1008.742 & 15 & 99133.4 & \\
\hline 1018.890 & 3 & 98146.0 & $15454_{13 / 2}-113600^{\circ}{ }_{13 / 2}$ & 1008.612 & 500 & 99146.2 & $12846_{9 / 2}-111993_{9 / 2}^{\circ}$ \\
\hline 1018.544 & 1 & 98179.4 & & 1008.536 & 3 & 99153.6 & $16516_{7 / 2}-115670^{\circ}{ }_{7 / 2}$ \\
\hline 1018.373 & 5 & 98195.8 & & 1008.285 & 2 & 99178.3 & $19700_{11 / 2}-118879^{\circ} 11 / 2$ \\
\hline 1018.242 & 100 & 98208.5 & $19872_{7 / 2}-118081_{9 / 2}^{\circ}$ & 1008.220 & $20 h$ & 99184.7 & \\
\hline 1017.853 & 2 & 98246.0 & $15045_{5 / 2}-113291_{7 / 2}^{\circ}$ & 1007.847 & 40 & 99221.4 & $14558_{9 / 2}-113780_{9 / 2}^{\circ}$ \\
\hline 1017.516 & 10 & 98278.6 & $18063_{9 / 2}-116309^{\circ}{ }_{11 / 2}$ & 1007.459 & 40 & 99259.6 & $\begin{array}{l}18063_{9 / 2}-117323^{\circ}{ }_{11 / 2} \\
21238_{13 / 2}-120498^{\circ}{ }_{13 / 2}\end{array}$ \\
\hline 1017.396 & $5 c l$ & 98290.1 & $17113_{13 / 2}-115403^{\circ}{ }_{1 / 2}$ & 1007.392 & 1 & 99266.2 & \\
\hline 1017.345 & $50 \mathrm{cl}$ & 98295.1 & $17113_{13 / 2}-115408^{\circ}{ }_{13 / 2}$ & 1007.336 & 7 & 99271.7 & $15525_{11 / 2}-114797^{\circ}{ }_{13 / 2}$ \\
\hline 1017.310 & $20 \mathrm{cl}$ & 98298.4 & $14859_{11 / 2}-113158_{9 / 2}^{\circ}$ & 1007.088 & 1 & 99296.2 & \\
\hline 1017.231 & 5 & 98306.1 & $17627_{9 / 2}-115933_{11 / 2}^{\circ}$ & 1006.829 & 3 & 99321.7 & \\
\hline 1016.991 & 10 & 98329.3 & & 1006.681 & 5 & 99336.3 & \\
\hline 1016.714 & 5 & 98356.1 & & 1006.383 & 3 & 99365.7 & \\
\hline 1016.471 & 200 & 98379.6 & $15454_{13 / 2}-113833^{\circ}{ }_{15 / 2}$ & 1006.221 & 3 & 99381.7 & \\
\hline 1015.785 & 20 & 98446.0 & $19872_{7 / 2}-118318_{7 / 2}^{\circ}$ & 1005.857 & 10 & 99417.7 & $13352_{11 / 2}-112769^{\circ}{ }_{13 / 2}$ \\
\hline 1015.730 & 10 & 98451.4 & & & & & $17627_{9 / 2}-117044_{7 / 2}^{\circ}$ \\
\hline 1015.699 & 2 & 98454.4 & & 1005.676 & 5 & 99435.6 & $18211_{5 / 2}^{9 / 2}-117647_{7 / 2}^{\circ}$ \\
\hline 1015.469 & 5 & 98476.7 & & 1005.584 & 1 & 99444.7 & \\
\hline 1015.340 & 1 & 98489.2 & & 1005.280 & 3 & 99474.8 & \\
\hline 1015.274 & 30 & 98495.6 & & 1004.912 & 30 & 99511.2 & \\
\hline 1015.170 & 8 & 98505.7 & & 1004.533 & 2 & 99548.8 & $1398_{11 / 2}^{\circ}-100947_{9 / 2}$ \\
\hline 1015.046 & 3 & 98517.7 & $29835_{9 / 2}-128352_{9 / 2}^{\circ}$ & 1004.259 & 1 & 99575.9 & \\
\hline 1014.815 & 3 & 98540.1 & & 1003.399 & 8 & 99661.2 & \\
\hline 1014.750 & 10 & 98546.4 & $29835_{9 / 2}-128381_{11 / 2}^{\circ}$ & 1003.258 & 10 & 99675.2 & \\
\hline 1014.622 & 30 & 98558.9 & $17113_{13 / 2}-115672^{\circ}{ }_{15 / 2}$ & 1002.876 & 1 & 99713.2 & \\
\hline 1014.231 & $10 \mathrm{cl}$ & 98596.9 & $19872_{7 / 2}-118468_{9 / 2}^{\circ}$ & 1002.724 & 1 & 99728.3 & \\
\hline 1014.202 & 100 & 98599.7 & $14558_{9 / 2}-113158_{9 / 2}^{\circ}$ & 1002.035 & $20 b l$ & 99796.9 & \\
\hline
\end{tabular}


TABLE X. Observed spectral lines of Pr III in the vacuum ultra violet region-Continued

\begin{tabular}{|c|c|c|c|c|c|c|c|}
\hline $\begin{array}{c}\lambda_{\text {vac }} \\
\AA\end{array}$ & Intensity & $\begin{array}{c}\sigma \\
\left(\mathrm{cm}^{-1}\right)\end{array}$ & Classification $^{a}$ & $\underset{\substack{\text { vac } \\
\AA}}{ }$ & Intensity & $\begin{array}{c}\sigma \\
\left(\mathrm{cm}^{-1}\right)\end{array}$ & Classification $^{\text {a }}$ \\
\hline 1001.528 & 4 & 99847.4 & & 979.694 & 2 & 102072.7 & \\
\hline 1001.224 & $50 \mathrm{cl}$ & 99877.7 & & 979.218 & 1 & 102122.3 & $19308_{11 / 2}-121431^{\circ}{ }_{13 / 2}$ \\
\hline 1001.197 & $20 \mathrm{cl}$ & 99880.4 & & & & & $26446_{7 / 2}-128568_{9 / 2}^{\circ}$ \\
\hline 1000.630 & 80 & 99937.0 & $14859_{11 / 2}-114797^{\circ}{ }_{13 / 2}$ & 978.001 & 4 & 102249.4 & $15525_{11 / 2}-117775_{13 / 2}^{\circ}$ \\
\hline & & & $16516_{7 / 2}-116453_{9 / 2}^{\circ}$ & 977.928 & 7 & 102257.0 & $18241_{11 / 2}-120498^{\circ}{ }_{13 / 2}$ \\
\hline 1000.525 & 7 & 99947.5 & $17627_{9 / 2}-117574_{11 / 2}^{\circ}$ & 976.676 & 10 & 102388.1 & $14859_{11 / 2}-117248^{\circ}{ }_{13 / 2}$ \\
\hline 1000.351 & 3 & 99964.9 & & 974.231 & 2 & 102645.1 & \\
\hline 1000.023 & 5 & 99997.7 & $21535_{9 / 2}-121532^{\circ}{ }_{11 / 2}$ & 973.100 & 3 & 102764.4 & $14558_{9 / 2}-117323^{\circ}{ }_{11 / 2}$ \\
\hline 999.499 & 30 & 100050.1 & & 972.263 & 1 & 102852.8 & \\
\hline 999.118 & 3 & 100088.3 & $21294_{7 / 2}-121382_{9 / 2}^{\circ}$ & 972.148 & 2 & 102865.0 & \\
\hline & & & $2893_{13 / 2}^{\circ}-102981_{13 / 2}$ & 971.675 & 10 & 102915.1 & $14859_{11 / 2}-117775_{13 / 2}^{\circ}$ \\
\hline 998.931 & 10 & 100107.0 & $18211_{5 / 2}-118318_{7 / 2}^{\circ}$ & 971.358 & 1 & 102948.6 & \\
\hline 998.827 & 1 & 100117.4 & & 970.727 & 5 & 103015.6 & $14558_{9 / 2}-117574_{11 / 2}^{\circ}$ \\
\hline 997.048 & 10 & 100296.1 & & 970.065 & 10 & 103085.9 & \\
\hline 996.885 & 1 & 100312.5 & $12846_{9 / 2}-113158_{9 / 2}^{\circ}$ & 969.090 & 20 & 103189.6 & $18241_{11 / 2}-121431^{\circ}{ }_{13 / 2}$ \\
\hline & & & $13352_{11 / 2}-113664^{\circ}{ }_{11 / 2}$ & 968.140 & 2 & 103290.8 & $18241_{11 / 2}-121532^{\circ}{ }_{11 / 2}$ \\
\hline 996.425 & 5 & 100358.8 & & 966.531 & 2 & 103462.8 & $12846_{9 / 2}-116309^{\circ}{ }_{11 / 2}$ \\
\hline 996.321 & 10 & 100369.3 & $18241_{11 / 2}-118610^{\circ}{ }_{13 / 2}$ & 965.313 & 10 & 103593.3 & $24788_{9 / 2}-128381^{\circ}{ }_{11 / 2}$ \\
\hline 995.957 & 2 & 100405.9 & $18063_{9 / 2}-118468_{9 / 2}^{\circ}$ & 964.531 & 1 & 103677.3 & \\
\hline 995.571 & 2 & 100444.9 & $12846_{9 / 2}-113291_{7 / 2}^{\circ}$ & 963.849 & 10 & 103750.7 & $14859_{11 / 2}-118610^{\circ}{ }_{13 / 2}$ \\
\hline 995.520 & $5 h$ & 100450.0 & & 954.857 & 8 & 104727.7 & $12846_{9 / 2}-117574_{11 / 2}^{\circ}$ \\
\hline 995.377 & 3 & 100464.4 & $14859_{11 / 2}-115324_{9 / 2}^{\circ}$ & 936.296 & 5 & 106803.8 & \\
\hline 994.598 & 70 & 100543.1 & $14859_{11 / 2}-115403^{\circ}{ }_{11 / 2}$ & 935.046 & 3 & 106946.6 & \\
\hline 994.545 & 6 & 100548.5 & $14859_{11 / 2}-115408^{\circ}{ }_{13 / 2}$ & 934.970 & 5 & 106955.3 & \\
\hline 994.380 & 3 & 100565.2 & $4453_{15 / 2}^{\circ}-105019_{13 / 2}$ & 934.074 & 2 & 107057.9 & $21294_{7 / 2}-128352_{9 / 2}^{\circ}$ \\
\hline 994.123 & 1 & 100591.2 & $16135_{7 / 2}-116727_{5 / 2}^{\circ}$ & 932.196 & 3 & 107273.6 & $21294_{7 / 2}-128568_{9 / 2}^{\circ}$ \\
\hline & & & $2893^{\circ}{ }_{13 / 2}-103484_{15 / 2}$ & 931.153 & 40 & 107393.7 & $25979_{15 / 2}-133373^{\circ}{ }_{17 / 2}$ \\
\hline 994.075 & 2 & 100596.0 & $4453^{\circ}{ }_{15 / 2}-105049_{15 / 2}$ & 920.003 & 1 & 108695.3 & \\
\hline 993.795 & 100 & 100624.4 & $15045_{5 / 2}-115670_{7 / 2}^{\circ}$ & 914.635 & 1 & 109333.2 & \\
\hline 993.642 & 2 & 100639.9 & $14859_{11 / 2}-115499_{9 / 2}^{\circ}$ & 913.825 & 60 & 109430.1 & \\
\hline 993.600 & 1 & 100644.1 & $17627_{9 / 2}-118271_{11 / 2}^{\circ}$ & 912.340 & 1 & 109608.3 & \\
\hline 993.422 & 4 & 100662.2 & $17113_{13 / 2}-117775^{\circ}{ }_{13 / 2}$ & 909.894 & 4 & 109902.9 & \\
\hline 992.169 & 5 & 100789.3 & $0_{9 / 2}^{\circ}-100788_{7 / 2}$ & 907.103 & 1 & 110241.1 & $18211_{5 / 2}-128453_{7 / 2}^{\circ}$ \\
\hline 992.085 & 30 & 100797.8 & $19700_{11 / 2}-120498^{\circ}{ }_{13 / 2}$ & 904.386 & 2 & 110572.2 & \\
\hline 990.750 & 5 & 100933.6 & $12846_{9 / 2}-113780_{9 / 2}^{\circ}$ & 903.766 & 2 & 110648.1 & \\
\hline 989.627 & 2 & 101048.2 & & 902.999 & 3 & 110742.1 & \\
\hline 989.381 & 20 & 101073.3 & $14859_{11 / 2}-115933_{11 / 2}^{\circ}$ & 896.172 & 1 & 111585.7 & \\
\hline 988.353 & 2 & 101178.4 & & 894.647 & 3 & 111775.9 & \\
\hline 988.001 & 60 & 101214.5 & $27138_{7 / 2}-128352_{9 / 2}^{\circ}$ & 890.276 & 1 & 112324.7 & \\
\hline 987.960 & 3 & 101218.7 & $1398^{\circ}{ }_{11 / 2}-102617_{11 / 2}$ & 889.296 & 2 & 112448.5 & \\
\hline 987.344 & 4 & 101281.8 & & 888.257 & 1 & 112580.0 & \\
\hline 987.023 & 2 & 101314.8 & $27138_{7 / 2}-128453^{\circ}{ }_{7 / 2}$ & 887.360 & 4 & 112693.8 & \\
\hline 985.880 & 2 & 101432.2 & $1398^{\circ}{ }_{11 / 2}-102830_{9 / 2}$ & 886.233 & 2 & 112837.1 & \\
\hline 985.120 & 3 & 101510.5 & $19872_{7 / 2}-121382_{9 / 2}^{\circ}$ & 885.575 & 2 & 112921.0 & \\
\hline 983.927 & 3 & 101633.6 & & 885.279 & 20 & 112958.7 & \\
\hline 983.461 & 8 & 101681.7 & $19700_{11 / 2}-121382_{9 / 2}^{\circ}$ & 884.158 & 40 & 113102.0 & \\
\hline 982.796 & 4 & 101750.5 & $14558_{9 / 2}-116309^{\circ} 11 / 2$ & 883.838 & 3 & 113142.9 & \\
\hline 982.709 & 20 & 101759.5 & $19360_{13 / 2}-121119^{\circ}{ }_{15 / 2}$ & 882.990 & 3 & 113251.6 & \\
\hline 982.340 & 1 & 101797.8 & $15525_{11 / 2}-117323^{\circ}{ }_{11 / 2}$ & 882.336 & 1 & 113335.5 & \\
\hline 979.899 & 1 & 102051.3 & $13352_{11 / 2}-115403^{\circ}{ }_{11 / 2}$ & 881.591 & 3 & 113431.3 & \\
\hline
\end{tabular}


TABLE X. Observed spectral lines of Pr III in the vacuum ultra violet region-Continued

\begin{tabular}{|c|c|c|c|c|c|c|c|}
\hline$\underset{\AA}{\lambda_{\text {vac }}}$ & Intensity & $\begin{array}{c}\sigma \\
\left(\mathrm{cm}^{-1}\right)\end{array}$ & Classification $^{\text {a }}$ & $\underset{\AA}{\lambda_{\text {vac }}}$ & Intensity & $\begin{array}{c}\sigma \\
\left(\mathrm{cm}^{-1}\right)\end{array}$ & Classification $^{\text {a }}$ \\
\hline 880.303 & 10 & 113597.2 & & 856.826 & 1 & 116709.8 & \\
\hline 879.840 & 2 & 113657.0 & & 856.740 & $2 h$ & 116721.5 & \\
\hline 879.441 & 10 & 113708.6 & $14859_{11 / 2}-128568_{9 / 2}^{\circ}$ & 856.285 & 1 & 116783.5 & \\
\hline 878.749 & 1 & 113798.1 & & 856.192 & 20 & 116796.2 & \\
\hline 878.215 & 10 & 113867.3 & & 855.808 & 3 & 116848.6 & \\
\hline 876.355 & 2 & 114109.0 & & 855.718 & 20 & 116860.9 & \\
\hline 876.305 & 1 & 114115.5 & & 855.422 & 1 & 116901.4 & \\
\hline 875.339 & 1 & 114241.4 & & 855.038 & 1 & 116953.9 & \\
\hline 874.680 & 2 & 114327.5 & & 854.692 & 1 & 117001.2 & \\
\hline 874.481 & 1 & 114353.5 & & 854.254 & 1 & 117061.2 & \\
\hline 874.173 & 1 & 114393.8 & & 853.782 & 2 & 117125.9 & \\
\hline 874.147 & 1 & 114397.2 & & 853.413 & 10 & 117176.6 & \\
\hline 874.051 & 1 & 114409.8 & & 853.318 & 2 & 117189.6 & \\
\hline 873.749 & 1 & 114449.3 & & 853.229 & 4 & 117201.8 & \\
\hline 872.569 & 1 & 114604.1 & & 853.120 & 1 & 117216.8 & \\
\hline 872.104 & 30 & 114665.2 & & 853.054 & 1 & 117225.9 & \\
\hline 871.932 & 1 & 114687.8 & & 852.968 & 1 & 117237.7 & \\
\hline 871.699 & 3 & 114718.5 & & 851.867 & 2 & 117389.2 & \\
\hline 871.069 & 2 & 114801.5 & & 851.524 & 2 & 117436.5 & \\
\hline 870.893 & 1 & 114824.7 & & 851.438 & 3 & 117448.4 & \\
\hline 869.598 & 1 & 114995.7 & & 851.361 & 8 & 117459.0 & \\
\hline 868.558 & 10 & 115133.4 & & 851.301 & 200 & 117467.3 & \\
\hline 868.490 & 1 & 115142.4 & & 851.168 & 15 & 117485.6 & \\
\hline 868.414 & 1 & 115152.4 & & 850.903 & 5 & 117522.2 & \\
\hline 866.285 & 4 & 115435.4 & & 850.331 & 5 & 117601.3 & \\
\hline 864.910 & 1 & 115619.0 & & 850.156 & $10 b l$ & 117625.5 & \\
\hline 864.582 & 1 & 115662.8 & & 850.061 & 1 & 117638.6 & \\
\hline 864.320 & 1 & 115697.9 & & 850.011 & 1 & 117645.5 & \\
\hline 863.941 & 8 & 115748.6 & & 849.895 & 20 & 117661.6 & \\
\hline 863.349 & 1 & 115828.0 & & 849.803 & 20 & 117674.3 & \\
\hline 863.131 & $3 h$ & 115857.3 & & 848.718 & 1 & 117824.8 & \\
\hline 862.823 & 2 & 115898.6 & & 848.657 & 10 & 117833.2 & \\
\hline 862.427 & 2 & 115951.8 & & 848.440 & 1 & 117863.4 & \\
\hline 862.227 & 1 & 115978.7 & & 847.729 & 1 & 117962.2 & \\
\hline 861.535 & 2 & 116071.9 & & 847.474 & 3 & 117997.7 & \\
\hline 861.498 & 1 & 116076.9 & & 846.565 & 2 & 118124.4 & \\
\hline 861.307 & 1 & 116102.6 & & 846.209 & 2 & 118174.1 & \\
\hline 860.721 & 2 & 116181.7 & & 845.710 & 7 & 118243.8 & \\
\hline 860.522 & 2 & 116208.5 & & 845.231 & 10 & 118310.8 & \\
\hline 860.313 & 3 & 116236.8 & & 845.066 & 5 & 118334.0 & \\
\hline 859.956 & 2 & 116285.0 & & 844.788 & 3 & 118372.9 & \\
\hline 859.730 & 3 & 116315.6 & & 844.395 & 100 & 118428.0 & \\
\hline 859.541 & 1 & 116341.2 & & 843.998 & 2 & 118483.7 & \\
\hline 859.299 & 1 & 116373.9 & & 843.887 & 10 & 118499.3 & \\
\hline 859.102 & 7 & 116400.6 & & 843.542 & $40 \mathrm{bl}$ & 118547.7 & \\
\hline 857.723 & 8 & 116587.8 & & 843.338 & 200 & 118576.4 & \\
\hline 857.614 & 1 & 116602.6 & & 843.312 & $10 \mathrm{cl}$ & 118580.1 & \\
\hline 857.348 & 5 & 116638.8 & & 842.497 & 40 & 118694.8 & \\
\hline 857.210 & 1 & 116657.5 & & 842.384 & 1 & 118710.7 & \\
\hline 857.091 & 1 & 116673.7 & & 842.130 & 1 & 118746.5 & \\
\hline
\end{tabular}

${ }^{\text {a }}$ For doubly-classified lines, the wavelength is entered only once. 
TABLE X. Observed spectral lines of $\operatorname{Pr}$ III in the vacuum ultra violet region-Continued

\begin{tabular}{|c|c|c|c|c|c|c|c|}
\hline $\begin{array}{c}\lambda_{\text {vac }} \\
\AA\end{array}$ & Intensity & $\begin{array}{c}\sigma \\
\left(\mathrm{cm}^{-1}\right)\end{array}$ & Classification $^{a}$ & $\lambda_{\mathrm{vac}}$ & Intensity & $\begin{array}{c}\sigma \\
\left(\mathrm{cm}^{-1}\right)\end{array}$ & Classification $^{a}$ \\
\hline 841.990 & 3 & 118766.2 & & 832.631 & 2 & 120101.2 & \\
\hline 841.779 & 1 & 118796.0 & & 832.164 & 1 & 120168.6 & \\
\hline 841.628 & $20 b l$ & 118817.3 & & 832.013 & 1 & 120190.4 & \\
\hline 841.426 & 8 & 118845.9 & & 831.919 & 3 & 120204.0 & \\
\hline 841.015 & 4 & 118903.9 & & 831.846 & 10 & 120214.6 & \\
\hline 840.890 & $30 \mathrm{cl}$ & 118921.6 & & 831.265 & 200 & 120298.4 & \\
\hline 840.871 & $10 \mathrm{cl}$ & 118924.3 & & 831.136 & 1 & 120317.2 & \\
\hline 840.459 & 6 & 118982.6 & & 830.927 & 2 & 120347.5 & \\
\hline 840.282 & 8 & 119007.7 & & 830.386 & 1 & 120425.9 & \\
\hline 840.057 & 60 & 119039.5 & & 830.061 & 2 & 120473.1 & \\
\hline 839.995 & 60 & 119048.3 & & 829.325 & 3 & 120580.0 & \\
\hline 839.619 & 1 & 119101.6 & & 828.364 & 50 & 120719.9 & \\
\hline 839.529 & 1 & 119114.4 & & 828.169 & 1 & 120748.3 & \\
\hline 839.474 & 2 & 119122.2 & & 828.134 & 1 & 120753.4 & \\
\hline 839.358 & $30 h$ & 119138.7 & & 827.34 .5 & 1 & 120868.6 & \\
\hline 838.933 & 30 & 119199.0 & & 825.989 & 30 & 121067.0 & \\
\hline 838.809 & 1 & 119216.6 & & 825.404 & 7 & 121152.8 & \\
\hline 837.712 & 2 & 119372.8 & & 824.880 & 3 & 121229.8 & \\
\hline 837.223 & 3 & 119442.5 & & 824.542 & 1 & 121279.4 & \\
\hline 836.744 & 8 & 119510.9 & & 823.117 & 1 & 121489.4 & \\
\hline 836.295 & 1 & 119575.0 & & 822.725 & 2 & 121547.3 & \\
\hline 835.843 & $15 b l$ & 119639.7 & & 822.467 & 15 & 121585.4 & \\
\hline 834.617 & 1 & 119815.4 & & 821.942 & 10 & 121663.1 & \\
\hline 833.478 & 10 & 119979.2 & & & & & \\
\hline 833.190 & 10 & 120020.6 & & & & & \\
\hline
\end{tabular}

a For doubly-classified lines, the wavelength is entered only once. 